$$
\text { UNIVERSIDADE DE SÃO PAULO }
$$

FACULDADE DE FILOSOFIA LETRAS E CIÊNCIAS HUMANAS

$$
\text { DEPARTAMENTO DE LETRAS MODERNAS }
$$$$
\text { PROGRAMA DE LÍNGUA ESPANHOLA E }
$$

LITERATURAS ESPANHOLA E HISPANO-AMERICANA

\author{
ALESSANDRA BROGNÁRA DE ASSIS
}

À PROCURA DE UM NORTE: FRONTEIRA E TERRITÓRIO EM NORTE, DE EDMUNDO PAZ SOLDÁN

Versão corrigida

São Paulo 
UNIVERSIDADE DE SÃO PAULO

FACULDADE DE FILOSOFIA LETRAS E CIÊNCIAS HUMANAS

DEPARTAMENTO DE LETRAS MODERNAS

PROGRAMA DE LÍNGUA ESPANHOLA E

LITERATURAS ESPANHOLA E HISPANO-AMERICANA

ALESSANDRA BROGNÁRA DE ASSIS

\section{À PROCURA DE UM NORTE: FRONTEIRA E TERRITÓRIO EM NORTE, DE EDMUNDO PAZ SOLDÁN}

\section{Versão corrigida}

Dissertação apresentada à área de Pósgraduação em Língua Espanhola e Literaturas Espanhola e Hispano-americana do Departamento de Letras Modernas da Faculdade de Filosofia, Letras e Ciências Humanas da Universidade de São Paulo para obtenção do título de Mestra em Letras.

Área de concentração: Literatura Hispanoamericana

Orientador: Prof. Dr. Pablo Gasparini

De acordo:

São Paulo 
Autorizo a reprodução e divulgação total ou parcial deste trabalho, por qualquer meio convencional ou eletrônico, para fins de estudo e pesquisa, desde que citada a fonte.

Catalogação na Publicação

Serviço de Biblioteca e Documentação

Faculdade de Filosofia, Letras e Ciências Humanas da Universidade de São Paulo

1. Literatura hispano-americana. 2. Literatura boliviana. I. Gasparini, Pablo Fernando, orient. II. Título.
} 
UNIVERSIDADE DE SÃO PAULO

FACULDADE DE FILOSOFIA, LETRAS E CIÊNCIAS HUMANAS

\section{ENTREGA DO EXEMPLAR CORRIGIDO DA DISSERTAÇÃO/TESE \\ Termo de Ciência e Concordância do (a) orientador (a)}

Nome do (a) aluno (a): Alessandra Brognára de Assis

Data da defesa: 16/07/2021

Nome do Prof. (a) orientador (a): Pablo Fernando Gasparini

Nos termos da legislação vigente, declaro ESTAR CIENTE do conteúdo deste EXEMPLAR CORRIGIDO elaborado em atenção às sugestões dos membros da comissão Julgadora na sessão de defesa do trabalho, manifestando-me plenamente favorável ao seu encaminhamento e publicação no Portal Digital de Teses da USP.

São Paulo, 26/08/2021 
FOLHA DE APROVAÇÃO

Nome: Alessandra Brognára de Assis

Título: À procura de um norte: fronteira e território em Norte, de Edmundo Paz

Soldán

Dissertação apresentada à Faculdade de Filosofia, Letras e Ciências Humanas da Universidade de São Paulo com vistas à obtenção do título de Mestra em Letras.

Aprovada em: 16/07/2021

Banca Examinadora

$\begin{array}{llll}\text { Nomes dos participantes } & \text { Função } & \text { Sigla da CPG } & \text { Resultado } \\ & & & \text { Não votante } \\ \text { Pablo Fernando Gasparini } & \text { Presidente } & \text { FFLCH-USP } & \text { Aprovado } \\ \text { Ana Cecilia Arias Olmos } & \text { Titular } & \text { FFLCH-USP } & \text { Aprovado } \\ \text { Isabel Cristina Jasinski } & \text { Titular } & \text { UFPR - Externo } & \text { Aprovado } \\ \text { Magdalena González Almada } & \text { Titular } & \text { UNC - ARG - Externo } & \text { Aprovalo }\end{array}$


Ao meu pai, Giuliano, e à minha mãe, Rita, pelo amor incondicional a mim devotado. 


\section{Agradecimentos}

À minha família materna, especialmente à minha mãe, à minha tia e madrinha Maria Aparecida, aos meus primos Thais, Juan e Renato e aos meus avós Cleusa e Olyntho, que já não habitam mais este plano, sem embargo me afagam em pensamento, por meio de doces memórias de infância.

À minha família paterna, especialmente ao meu pai, aos meus tios Giovani, Germana e Ana Paula e ao meu avô João.

Ao meu orientador, Pablo Gasparini, o qual me deu todo o apoio necessário para o bom desenvolvimento desta pesquisa, auxiliando-me a avançar por meio de seu olhar atento e de suas palavras gentis.

Ao meu companheiro, Tiago, que esteve ao meu lado durante a escrita de cada uma destas palavras, mostrando-se um ouvinte dedicado em meus momentos de brainstorming.

À família Kodama: Alexandre, Emi, Alissa, Titi, Shiori e Ryouta; e ao Jimmy que, assim como eu, é Kodama de coração.

Às professoras Ana Cecília Olmos e Adriana Kanzepolsky pelas preciosas considerações durante o exame de qualificação, bem como pelas maravilhosas aulas durante a gradução, as quais foram fundamentais para meus estudos literários e das quais lembro com tanto carinho.

Aos demais professores da Faculdade de Filosofia, Letras e Ciências Humanas da Universidade de São Paulo, cujas aulas formaram muito de quem sou.

Aos professores Carlos Garatea, Wanderley Messias da Costa e Francisco Ernesto Zaragoza Zaldivar pelas disciplinas da pós-graduação que tanto contribuíram para a realização desta dissertação.

À professora Magdalena González Almada pelos ensinamentos compartilhados em seu curso sobre a literatura boliviana contemporânea e por compor esta banca de defesa junto à professora Isabel Cristina Jasinski, a quem também agradeço. 
À Coordenação de Aperfeiçoamento de Pessoal de Nível Superior (CAPES) pela bolsa concedida para que eu pudesse me dedicar a esta pesquisa.

À Graziela Drago, pela amizade e por aceitar a missão de ser minha revisora.

E, last but not least, ao Edmundo Paz Soldán, sem o qual (obviamente) nada do que está escrito aqui seria possível. 
[...] El alma del extranjero. Del extraño.Del introducido. Del intruso. Del huido. Del vagabundo. Del errante. ¿Alguien 10 sabía? ¿Alguien, acaso, sabía cómo se encontraba el alma del extranjero? ¿El alma del extranjero estaba dolorida? ¿Estaba resentida? ¿Tenía alma el extranjero?

(Cristina Peri Rossi, La nave de los locos). 


\section{Resumo}

ASSIS, Alessandra Brognára de. À procura de um norte: fronteira e território em Norte, de Edmundo Paz Soldán. 113 páginas. Dissertação(Mestrado) Faculdade de Filosofia, Letras e Ciências Humanas, Universidade de São Paulo. São Paulo, 2021.

Esta dissertação de mestrado tem como objeto de análise o romance Norte, do autor boliviano Edmundo Paz Soldán, publicado em 2011, pela editora Mondadori. Trata-se de uma obra cujo enredo se desdobra em três linhas narrativas, situadas em temporalidades diversas, mas que possuem entre si um elo: seus personagens são sujeitos fronteiriços, imigrantes latino-americanos que rumaram ao norte, ao solo estadunidense. Aqui, propõe-se estudar os processos de (des)territorialização a que essas diferentes subjetividades se vêem submetidas como resultado de seu deslocamento migratório, atendendo para isto tanto às dinâmicas desterritorializantes como aquelas que, através da arte, da delinquência e da escrita tentam inscrever o sujeito em novos territórios subjetivos e sociais. Para isso, assentamo-nos teoricamente em diversas reflexões sobre as incidências subjetivas das mudanças de língua e lugar, priorizando os estudos de Haesbaert (2002, 2003, 2004 e 2007) sobre território e territorialidade. Cada uma dessas linhas narrativas recebe, desse modo, um capítulo que visa interpretar como as problemáticas de fronteira e território são aproveitadas para o desenvolvimento específico de uma ficção atravessada por gêneros variados (o romance negro e o romance de campus, predominantemente).

Palavras-chave: Edmundo Paz Soldán; literatura boliviana contemporânea; território; fronteira; imigração. 


\begin{abstract}
ASSIS, Alessandra Brognára de. The Pursuit of a north: borderland and territory in Norte, by Edmundo Paz Soldán. 113 pages. Dissertation (Master) - Faculdade de Filosofia, Letras e Ciências Humanas, Universidade de São Paulo. São Paulo, 2021.
\end{abstract}

This master's dissertation has as its object of analysis the novel Norte, by the Bolivian author Edmundo Paz Soldán, published in 2011, by the publisher Mondadori. It is a work whose plot unfolds in three narrative lines, located in different temporalities, but which have a link between them: their characters are borderline subjects, Latin American immigrants who headed north, to American soil. Here, it is proposed to study the processes of (de)territorialization to which these different subjectivities are subjected as a result of their migratory displacement, taking into account both the deterritorializing dynamics and those that, through art, delinquency and writing, try to inscribe the subject in new subjective and social territories. For this, we theoretically based on several reflections on the subjective incidences of changes in language and place, prioritizing Haesbaert's studies (2002, 2003, 2004 and 2007) on territory and territoriality. Each of these narrative lines receives, in this way, a chapter that aims to interpret how the border and territory problematic are used for the specific development of a fiction crossed by varied genres (the black romance and the campus romance, predominantly).

Keywords: Edmundo Paz Soldán; 21th century Bolivian literature; territory; borderland; immigration. 


\section{Resumen}

\section{ASSIS, Alessandra Brognára de. En busca de un norte: frontera e territorio}

en Norte, de Edmundo Paz Soldán. 113 páginas. Disertación (Maestría). Faculdade de Filosofia, Letras e Ciências Humanas, Universidade de São Paulo. São Paulo, 2021.

Esta disertación de maestría tiene como objeto de análisis la novela Norte, del autor boliviano Edmundo Paz Soldán, publicada en 2011, por la editorial Mondadori. Es una obra cuya trama se desarrolla en tres líneas narrativas, ubicadas en diferentes temporalidades, pero que tienen un vínculo entre ellas: sus personajes son sujetos fronterizos, inmigrantes latinoamericanos que se dirigieron al norte, al suelo estadunidense. Aquí se propone estudiar los procesos de (des)territorialización a los que se ven sometidas estas distintas subjetividades como consecuencia de su desplazamiento migratorio, teniendo en cuenta tanto las dinámicas desterritorializadoras como las que, a través del arte, de la delincuencia y de la escritura, pretenden inscribir el sujeto en nuevos territorios subjetivos y sociales. Para ello, nos basamos teóricamente en varias reflexiones sobre las incidencias subjetivas de los cambios de lengua y lugar, priorizando los estudios de Haesbaert (2002, 2003, 2004 y 2007) sobre territorio y territorialidad. Cada una de estas líneas narrativas recibe, de esta manera, un capítulo que pretende interpretar cómo se utilizan los problemas de frontera y territorio para el desarrollo específico de una ficción atravesada por géneros variados (el romance negro y el romance universitario, predominantemente).

Palabras clave: Edmundo Paz Soldán; literatura boliviana contemporánea; territorio; frontera; inmigración. 


\section{Sumário}

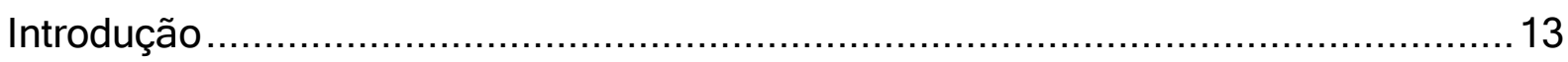

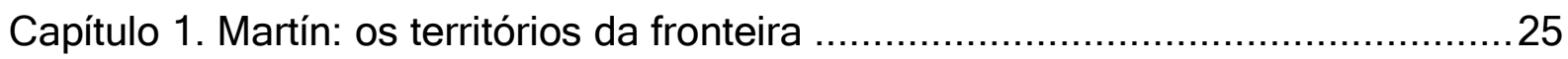

1.1 O embate de representações em Martín Ramirez.........................................26

1.2 A arte psiquiátrica como ferramenta de reterritorialização ................................35

$1.3 \mathrm{O}$ migrante como sujeito fronteiriço ...................................................... 47

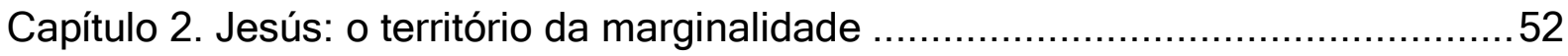

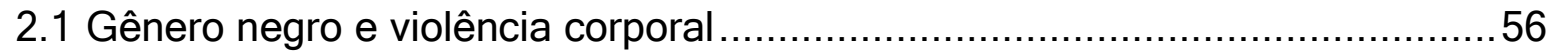

2.2 Heterotopia e espaços delinquenciais .....................................................65

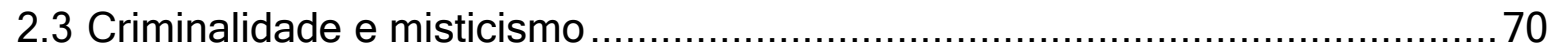

Capítulo 3. Michelle: o território do campus universitário ……….........................79

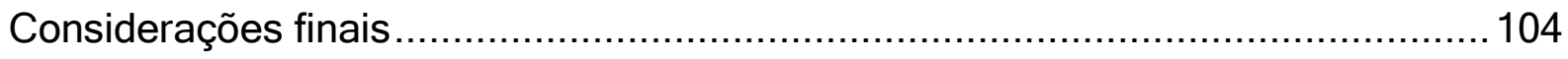

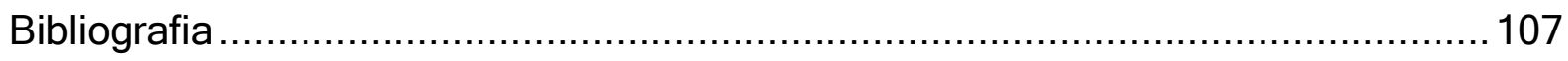




\title{
Introdução
}

\begin{abstract}
Si se dice que Bolivia es una formación abigarrada es porque en ella no sólo se han superpuesto las épocas económicas (las del uso taxonómico común) sin combinarse demasiado, como si el feudalismo perteneciera a una cultura y el capitalismo a otra y ocurrieran sin embargo en el mismo escenario o como si hubiera un país en el feudalismo y otro en el capitalismo, superpuestos y no combinados sino en poco. (ZAVALETA, 1983, p. 6).
\end{abstract}

Estudar a Bolívia e sua literatura é, já desde o primeiro momento, adentrar em uma sociedade "abigarrada", a qual consegue ser ao mesmo tempo, dois lados frequentemente vistos como opostos: tradição e modernidade, oralidade e escrita, transformam-se organicamente em uma espécie de colcha de retalhos social. Nesse ponto, cabe trazer René Zavaleta Mercado, um dos principais sociólogos bolivianos do século $X X$, que em sua análise das particularidades da Bolívia considera o país como detido em duas "épocas económicas" distintas, mas que ali convivem superpostas (ZAVALETA, 1983, p. 6). Localizada na parte central da América do Sul, trata-se de um país que promove discursos geopolíticos controversos, sendo já tratado por estudiosos como "absurdo geográfico", "área estratégica para a contenção sulamericana" e "área estratégica para integração sul-americana" (PFRIMER, 2011, p. 133).

É em meio a esse intricado caldo cultural que, desde o final do século $X X$, a literatura do país vem passando por um processo de reconfiguração, tanto no que diz respeito àquela que é feita por escritores que atualmente residem dentro dos limites nacionais e ali produzem suas obras, quanto por bolivianos que o fazem desde o exterior. Utilizando a força de suas vozes narrativas, esses autores têm procurado ressignificar a ideia de pertencimento a um território e questionam a ilusória imutabilidade de tal condição, além de transmutarem elementos e temas até então típicos à sua tradição literária, como o constante retorno à idealização costumbrista, o qual diversas vezes vem acompanhado do apego ao rural e ao indígena (ALMADA, 2013). Isso tudo é feito de forma a transfigurar valores até então consolidados, sem que a potência política da literatura seja diminuída, senão transformada para atender à atual conjuntura do país e às demandas de sua juventude.

Desse modo, para eles é importante que sejam retratadas ambas as faces do país, afinal a modernidade que os levou a possuir, desde 2013 , o próprio satélite de 
comunicação, alia-se à tradição ao denominá-lo Tupac Katari, em homenagem ao homônimo guerrilheiro indígena do século XVIII. É justamente por conta da peculiaridade de se tratar de uma "sociedade abigarrada" (ZAVALETA, 1983) que tensiona-se pensar a Bolívia por meio da reformulação literária e dos impactos que ela promove no imaginário coletivo. A nova narrativa boliviana propõe, antes de tudo, uma forma de pensar o país e sua cultura, interpretando-o a partir do contexto do século XXI.

Maximiliano Barrientos, Juan Pablo Piñeiro, Liliana Colanzi, Sebastián Antezana, Mauro Alwa, Magela Baudoin, Fabiola Morales, Rodrigo Hasbún e, finalmente, Edmundo Paz Soldán são alguns dos muitos escritores que vêm construindo essa literatura boliviana contemporânea, cada qual atuando a partir de suas singularidades e trazendo, com isso, uma narrativa crítica, que permite pensar os sujeitos sociais da atualidade.

Nesta dissertação, buscamos promover um estudo analítico-interpretativo de uma dessas obras, tão cara à nova conformação literária boliviana. O livro Norte (2011), de Edmundo Paz Soldán, tem como base uma narrativa pautada pelo deslocamento e pela imigração. Seu enredo, ainda que não esteja espacialmente ancorado no território boliviano, mas no fronteiriço e conflituoso espaço que é constituído entre o norte do México e sul dos Estados Unidos, possui na personagem Michelle eem sua família uma forma de inserir na obra um pouco da complexidade da cultura boliviana, de modo a pautar também a questão da adaptação no país estrangeiro. Ainda assim, tal elaboração não impede que outras problemáticas territoriais e fronteiriças sejam postas voga, inclusive por meio dessa mesma personagem.

Por conta disso, acreditamos possuir na estrutura criativa da obra um forte apelo às questões territoriais, as quais demonstram ter poder de (des)construir seus sujeitos, isto é, os complexos personagens do romance. Nele, estão presentes fronteiras fundamentais, que se constroem tanto fisicamente, ou seja, em plena materialidade, quanto as que dizem respeito ao campo do simbólico. Assim, tais fronteiras são parte estrutural desses territórios, o que nos parece ser tão elementar para a intriga da obra que se tornou o recorte temático desta pesquisa.

No que se refere à bibliografia específica mobilizada para os estudos sobre território, territorialização e reterritorialização, o trabalho do geógrafo brasileiro 
Haesbaert (2002, 2003, 2004 e 2007) foi crucial para a consolidação do conceito, que serve de base para toda a investigação. Além disso, a apreciação de Borderlands/La frontera, de Gloria Anzaldúa (1987), obra ícone para se trabalhar com a questão do sujeito fronteiriço, provou-se fundamental, direta ou indiretamente, em todos os capítulos.

Nesse ponto, o próprio Paz Soldán pode ser pensado como um desses sujeitos migrantes, os quais ele traz frequentemente como personagens de seus romances e contos, já que se trata de um autor que se deslocou de sua Bolívia natal paraos Estados Unidos, onde trabalha como professor da área de literatura latino-americana da Universidade de Cornell. Esse deslocamento pode ser um dos fatores que ajudaram a gerar certa dubiedade da crítica para entender a sua produção dentro de alguma linha literária específica.

O autor foi filiado por alguns críticos no grupo de escritores que se deram em chamar "Geração McOndo"1, visto que compôs a equipe que produziu a antologia de mesmo nome. Entretanto, outos críticos enquadram o autor na geração do Crack, movimento nascido no México, sobre o qual Díez Cobo tece a seguinte afirmação:

[...] la generación mexicana del Crack se distancia por su propuesta de carácter más intelectualista. Y esto es así, puesto que sus proponentes buscan primordialmente una reforma poética fundamentada en el distanciamiento con los modelos inmediatamente previos del Posboom aspirando a una literatura de mayor exigencia formal y que, de algún modo, recupere el espíritu del Boom en su concepción más elitista y elaborada de "la novela profunda" que definiese John S. Brushwood, es decir, primando la experimentación formal y requiriendo del lector una "participación activa", como ensu momento también defendiese Julio Cortázar.(DÍEZ COBO, 2009, p. 2).

Para Eduardo Becerra (2008) é possível pensar o autor no contexto de ambos os movimentos mencionados:

Paz Soldán participó en McOndo, pero ha desplegado una narrativa que en algunos aspectos se asimila a los postulados del Crack, en lo que tiene de intento de reflejar ciertas coordenadas culturales y políticas del mundo actual a través de la reescritura de algunos de los grandes metarrelatos

\footnotetext{
${ }^{1}$ Em 1996 é publicada a antologia de contos McOndo pela editora Mondadori. Fundamentado em um realismo mais autêntico em relação à verdadeira vivência nos países latino-americanos, o movimento busca desvencilhar-se do realismo mágico embasado no exotismo. Sobre o movimento, Hargrave e Seminet afirmam: "El motivo que movió a los editores de McOndo a compilar la antología era demostrar que el realismo mágico no es el único estilo representativo de la literatura latinoamericana. Segúnellos, la percepción de los lectores europeos y norteamericanos de la literatura latinoamericana ha sido que debe reflejar un mundo natural, folklórico y mítico. Por lo tanto, esta antología es producto del esfuerzo de reunir a unas voces literarias contemporáneas que representan otra faceta de la realidad latinoamericana." (HARGRAVE e SEMINET, 1998, p. 14).
} 
latinoamericanos del pasado. (BECERRA, 2008, p. 173).

Siskind (2016, p. 146), por sua vez, explica que McOndo é um "proyecto literario, pero también político-cultural' de contestação à expectativa estrangeira e mercadológica, principalmente norte-americana e europeia, de que a produção literária latino-americana siga anacronicamente desenvolvendo-se nas mesmas bases estéticas do realismo mágico que era feito no período do boom, ignorando a mudança conjuntural.

Como oposição a isso, Fuguet (1996) propõe, na introdução da antologia de contos, a escrita de narrativas que se fundamentem naquilo que ele chama de "realismo virtual", afastando-se da "fórmula del realismo mágico". (FUGUET ano da citação original apud Siskind, 2016, p. 146). A esse respeito, Diana Palaversich explicao conceito proposto por Fuguet, em seu livro De Macondo a McOndo: senderos de lapostmodernidad latinoamericana. Nele, a autora explica que ele se baseia na construção do imaginário de uma América Latina contemporânea, globalizada e neoliberal, inserida na era da internet e do mercado editorial internacional. É dessa maneira que os intelectuais partidários de tais ideais, como Paz Soldán, acreditam ser "ciudadanos del mundo", o que os leva a produzir uma literatura tida como mais atrativa comercialmente. (PALAVERSICH, 2005, p. 56). No caso do autor, ele segue tal premissa maravilhosamente bem ao tematizar em suas obras as complexidades das sociedades contemporâneas, como explosão da violência urbana, o excesso de exposição às telas e a hiperconexão. São exemplos disso os livros do autor Sueños digitales (2000), El delirio de Turing (2004) e Iris (2014). Dessa forma, o autor buscaria contribuir para a "refundación de la literatura latinoamericana, ahora plenamente inscripta en los flujos del capital neoliberal" (SISKIND, 2016, p. 146).

A obra Norte, aqui trabalhada, é o nono romance publicado pelo autor, sendo o segundo em que a espacialidade da trama ancora-se em terras estadunidenses, já que o primeiro é Los vivos y los muertos (2009). Desse modo, o livro integra à obra de Paz Soldán de forma a constituir parte de uma espécie de trilogia primeiramente pensada pelo autor. São livros que, apesar de não possuírem os mesmos personagens, tampouco versarem sobre exatamente o mesmo tema, possuem em comum o fato de trabalharem os desdobramentos da vida imigrante nos Estados Unidos e trazerem personagens psicologicamente transtornados. Além disso, destaca-se o aspecto de morbidez, que impregna as narrativas. Assim, a obra aqui 
trabalhada reúne-se, nesses pontos, aos romances supracitados Los vivos y los muertos (2009)e Iris (2014).

Edmundo Paz Soldán nasceu na cidade de Cochabamba, no ano de 1967, em meio a uma Bolívia pobre e agrária, cuja composição política em desalinho havia feito com que surgisse, em 1941, o Movimiento Nacionalista Revolucionario (MNR). Tal organização protagonizou uma revolução de cunho popular, como forma de protesto, a qual foi denominada Revolução de 1952, por deflagrar-se no ano em questão, transformando-se mais tarde em um partido político de mesmo nome. De acordo com o político contemporâneo Carlos Mesa, em cuja carreira constao mandato como presidente do país entre os anos de 2003 e 2005, trata-se do partido "probablemente más influyente de toda nuestra historia republicana" (MESA apud CAMARGO, 2006, p. 141-142). O movimento traz mudanças sócio-políticas profundas como o sufrágio universal e a forte presença do Estado nas questões econômicas de mercado, visando atenuar a abismal diferença de classes no país. Camargoé um dos pensadores que trabalha o tema do legado da revolução:

\begin{abstract}
A Revolução, modificando o etos político e econômico boliviano, deixou legado durável e arraigado, que sobreviveu ao interregno autoritário-militar de 1964-1982 e, reeditado no programa de governo da Unidad Democrática y Popular (UDP), somente desaparece em 1985, no contexto da gravíssima crise econômica que encerra, de fato, o chamado Estado de 1952 e abre o ciclo da Bolívia neoliberal. (CAMARGO, 2006, p. 161-162).
\end{abstract}

Apesar desse importante contexto sociopolítico de seu país de origem, o autor afirma, todavia, não encontrar ali, durante sua formação, referenciais fortes de escritores bolivianos, o que fez com que autor declarasse que durante a produçãode seus primeiros escritos desconhecia a tradição literária de seu próprio país, jáque, segundo ele: "[...] yo no conocía la tradición boliviana, y decidí crearme la mía propia y mirarme en el espejo de Borges, Kafka y Vargas Llosa." (PAZ-SOLDÁN, 2004, p. 43). A reconfiguração de territórios simbólicos sociais na Bolívia é similar àquela ocorrida em seu vizinho andino, o Peru, mas a escolha de Paz Soldán a respeito de qual intelectual peruano seguir pontua uma forma de ver tal problemática. Por que Vargas Llosa e não Arguedas? Ao elegir a literatura de Vargas Llosa como modelar, o autor opta, interessantemente, pelo "zorro de abajo", em detrimento do "zorro de arriba".

Tal admiração de Paz Soldán por Vargas Llosa é reafirmada em alguns textos do autor, sendo um exemplo disso o artigo Cuatro lecturas de "La ciudad y los perros", no qual o autor boliviano conta como sentiu emocionado ao conhecê-lo em um jantar, 
uma vez que a produção literária deste havia sido o grande referente linguístico para sua literatura. Nesse ponto, ele relembra sua segunda leitura do romance do autor peruano:

\begin{abstract}
Así redescubrí esa novela que me había impactado tanto. [...] ahora me llamaba la atención el lenguaje y el mundo social narrado con ese lenguaje. Había palabras y construcciones sintácticas que pertenecían al español que se hablaba en Bolivia - fregar, chompa, en su delante - y yo sentía que se legitimaban al estar en un libro así, y de paso legitimaban la posibilidad de que mi español fuera un instrumento para la literatura. (PAZ-SOLDÁN, 2013, p. 4).
\end{abstract}

Paz Soldán afirma, todavia, ao ser entrevistado para o canal L, que em Norte a influência de Vargas Llosa se dá de modo menos evidente do que quando comparada a seus outros romances, já que a estrutura narrativa fragmentada adotada na obra constrói enredos que possuem uma "conexión más simbólica que de trama", enquanto nos livros do autor peruano há uma tendência para uma confluência de linhas narrativas. Vargas Llosa, por sua vez, ao falar do escritor boliviano, afirma que se trata de "una de las voces más creativas de la actual literatura hispanoamericana", conforme consta na contracapa da edição utilizada neste estudo. ${ }^{2}$

Tendo como incentivo uma bolsa como jogador de futebol na Universidade do Alabama, em Huntsville, nos Estados Unidos, Paz Soldán se muda para o país e, após concluir a graduação em Ciências Políticas na mesma universidade, modifica seu campo de estudos ao doutorar-se em literatura latino-americana na Universidade de Berkeley, sendo a partir daí que desenvolve sua produção acadêmica na área de literatura, atuando mais tarde como professor na Universidade de Cornell. Já no que se refere à obra aqui analisada, Paz Soldán foi finalista do prêmio Hammett, em 2012 (Semana Negra de Gijón), por sua elaboração.

O gênero dos romances privilegiados por esse prêmio, talvez possa dizernos algo sobre a natureza das histórias narradas em Norte, já que se trata de histórias nada tranquilizadoras sobre a fronteira e a imigração, mas antes abordadas a partir de uma conflitividade que compromete os corpos e as vidas, sendo que algumas dessas histórias, como veremos, envolvem inclusive delinquência, marginalidade e criminalidade.

Os conceitos de territorialidade e fronteira surgem por tratarem-se de tópicos que perpassam todo o romance, compondo sua estrutura temática. Todos os

\footnotetext{
${ }^{2}$ PAZ-SOLDÁN, 2011.
} 
personagens estão em processo de (re)construção da própria territorialidade em solo estrangeiro, experienciando uma vida em fronteira, a qual se delineia não apenas nos limites do desenho geográfico, mas também em tudo aquilo que se conforma no âmbito do abstrato, como o limiar entre sanidade e loucura, por exemplo.

A fronteira, seja ela simbólica ou física, é presença central no romance e traz consigo a característica de ser uma territorialidade em constante conflito. É viva e pulsante. Corta e expõe os corpos inquietos que a ousam cruzar e é exatamente por isso que não devemos naturalizá-la. Pelo contrário, sua problematização perpassa também vê-la como uma construção humana, portanto passível de desconstrução e reformulação, ainda que isso se dê lentamente. Além disso, é um conceito paradoxal por deslocar-se entre o subjetivo e o objetivo, de forma a não se cristalizar, de fato, em nenhum desses lados. Trata-se do elemento alterador na trajetória dos personagens.

A obra Norte é constituída por três linhas narrativas, encadeadas com tal fluidez que o único auxílio ao leitor está em pequenas epígrafes no topo de cada capítulo, nas quais é informado o tempo e o espaço em que transcorrerão as ações narradas no capítulo em questão. Esse auxílio tempo-espacial é um dos aspectos que permite lermos a dimensão territorial dos capítulos em seus cronotopos narrativos, tais quais os concebe Bakhtin (ano da citação original, apud Amorin, 2006), já que personagem, tempo e espaço se unem em prol da significação textual. Daí a importância de pensálos enquanto um conjunto, afinal o aqui e o agora são fundamentais para a constituição de cada um desses sujeitos, ressaltando seu caráter de ser em maior ou menor medida alguém que passa constantemente pelos processos de socialização criados e frequentemente reforçados pelos próprios territórios fronteiriços em que estão inseridos.

O primeiro personagem a ser apresentado ao leitor é Jesús, um jovem que, após cometer seu primeiro crime quase que acidentalmente, transforma-se gradualmente em um serial killer dentre os mais procurados dos Estados Unidos. Trata-se de uma história inspirada em um criminoso verdadeiro, denominado pela indústria midiática como "The Railroad Killer". Para sua composição, Paz Soldán declara, em uma nota no final da edição, que se trata de uma versão livre imaginada principalmente a partir da leitura de The Railroad Killer, de Wensley Clarkson (1999). Martín, protagonista de outra linha narrativa, chegou aos Estados Unidos no 
começo do século $X X$ e, após uma sequência de empregos mal remunerados, trabalhou na construção das ferrovias durante seu período de auge (interrompido nos anos 1930 pela Grande Depressão). Depois de ser encontrado cometendo atos de vandalismo em uma estação de trem, é levado a um hospital psiquiátrico e é nesse ambiente que seu viés artístico aflora. Através de pinturas e colagens, Martín encontra outra possibilidade de se comunicar com o mundo, abandonando a linguagem verbal e abordando em suas obras os lugares-comuns de seu delírio esquizofrênico. Assim como o anterior, este também foi inspirado em um sujeito real, cuja base de criação (localizada na previamente citada nota explicativa ao final da obra) seria, segundo o autor, o livro Martín Ramírez, editado por Brooke Davis Anderson (2007).

Já Michelle, única personagem puramente fictícia e cujo relato é narrado em primeira pessoa, é uma estudante que renunciou ao doutorado para seguir o que acredita ser sua verdadeira vocação: desenvolver uma produção própria como escritora e desenhista de comics e contos, nos quais insere elementos da cultura pop, como zumbis e vampiros. Ademais, sua história é entrecortada por uma relação abusiva com o professor argentino Fabián, que desde seu egocentrismo e paranoia faz uso de sua posição de poder para manipular a personagem.

O que reune essas três histórias em uma lógica comum é o fato de que, em meio à síncrese de culturas ocasionada pela posição fronteiriça e marginal na qual se encontram os personagens, cada um deles tenta construir territórios alternativos, conforme os concebe Lefebvre, os quais define como "contra-espaços" de resistência em que se corrompe a ordem hegemônica pré-estabelecida ${ }^{3}$. $O$ território, de fato, não é algo fixo ou determinado de uma vez e para sempre. Ele muda de acordo com a mudança de relações sociais no seu interior. Marcelo Lopes de Souza (2001), em seu artigo sobre as várias concepções de território que estão presentes no âmbitoda Geografia, propõe a seguinte definição:

Territórios, que são no fundo antes relações sociais projetadas no espaço que espaços concretos (os quais são apenas substratos das territorialidades voltar-se-á a isso mais adiante), podem, conforme já se indicara na introdução, formar-se e dissolver-se, constituir-se e dissipar-se de modo relativamente rápido (ao invés de uma escala temporal de séculos ou décadas, podem ser simplesmente anos ou mesmo meses, semanas ou

\footnotetext{
${ }^{3}$ Lefebvre coloca em sua síntese das características da complexidade do conceito do espaço social o seguinte tópico: "contém as virtualidades, aquelas da obra e da reapropriação, sobre o modo da arte, mas sobretudo segundo as exigências do corpo [...]", seja espaço de uma contra-cultura, seja contraespaço, ou alternativa primeiro utópica ao espaço "real" existente. (LEFEBVRE apud TONUCCI FILHO, 2013, p. 43).
} 
dias), ser antes instáveis que estáveis ou, mesmo, ter existência regular mas apenas periódica, ou seja, em alguns momentos - e isto apesar de que o substrato espacial permanece ou pode permanecer o mesmo. (SOUZA, 2001, p. 87).

Ainda no mesmo texto, Souza dá sequência a sua argumentação pautando que, além da importância do caráter temporal para que nos espaços conformem-se territórios, há também uma questão crucial que diz respeito às dimensões política e cultural:

Outra forma de abordar a temática da territorialidade, mais abrangente e crítica, pressupõe não propriamente um descolamento entre as dimensões política e cultural da sociedade, mas uma flexibilização da visão do que seja território. Aqui, o território será um campo de forças, uma teia ou rede de relações sociais que, a par de sua complexidade interna, define, ao mesmo tempo, um limite, uma alteridade: a diferença entre nós (o grupo, os membros da coletividade ou "comunidade", os insiders) e os "outros" (os de fora, os estranhos, os outsiders). (SOUZA, 2001, p.86).

Os personagens do romance, desse modo, estão imersos em suas ressignificações territoriais, as quais são diversas vezes interpretadas socialmente como loucura (o que se passa com os personagens Jesús e Martín, que serão abordados nos primeiros e segundos capítulos desta dissertação) ou hesitação existencial (como éo caso de Michelle, conforme se abordará, por sua vez, no terceiro), não restando alternativa a não ser a vida como outsider, descobrindo por si só as próprias possibilidades de existir e residir em um espaço acadêmico em que prestígio e rejeição estão cada vez mais próximos.

É através desse intrincado desenvolvimento narrativo, no qual se alternam as possibilidades temporais e espaciais, que as três histórias ocorrem simultaneamente, ainda que demarcadas por suas esferas de ação. É somente a partir de sutilezas simbólicas e de uma trama bem amarrada tematicamente que o leitor tem plena consciência de não estar lendo três romances diferentes impressos de modo a se agruparem, mas um só.

Esta dissertação se dividirá, portanto, consoante às problemáticas presentes em cada uma das linhas narrativas da obra, organizando-se de maneira cronológica, sendo o primeiro capítulo designado à história cujo personagem principal é Martín, o segundo centra-se em Jesús e o terceiro, por sua vez, nas complexidades da personagem Michelle. Os personagens secundários pertencentes a cada um desses espaços narrativos serão também trabalhados, uma vez que são também essenciais para a interpretação da obra. 
O primeiro capítulo, destinado ao personagem baseado no pintor diagnosticado com esquizofrenia Martín Ramírez centra-se nas diversas figurações subjetivas que este assume ao longo do romance, bem como nas problemáticas da loucura eda arte feita por pessoas caracterizadas como loucas, buscando determinar as estratégias utilizadas pelo narrador para construir a possível insanidade do personagem. Tudo isso será feito de modo a perpassar a análise de sua construção enquanto sujeito fronteiriço, culminando em sua busca por uma territorialidade menos opressiva, o que ocorre tanto através de sua prática, como de seu objeto artístico, apesar da limitação física imposta pela instituição psiquiátrica na qual está internado. Como referências bibliográficas, neste capítulo mobilizam-se os estudos de João Frayze-Pereira (1985), Michel Foucault (1997) e Erving Goffman (1961) e Daniela Arbex (2019) sobre a insanidade e os espaços asilares psiquiátricos. Além disso, trazemos as pesquisas específicas a Martín Ramírez feitas por Espinosa (2015) e Irwin (2014), assim como um artigo de Martín Guijón (2011) sobre Norte. Já a problemática da arte feita por pessoas internadas em instituições psiquiátricas é abordada à luz de Franco (2011), Andriolo (2004) e Dubuffet (1986). Tudo isso com o intuito de traçar relações entre o personagem e a construção de uma territorialidade fronteiriça por se tratar de uma subjetividade imigrante em meio ao hermetismo hospitalar, que aliena seus internos.

O segundo capítulo, no qual se abordam as problemáticas do personagem Jesús, tem como alvo de análise as relações estruturadas pela lógica da violência, visando pensar em como a saída do território da lei o coloca em heterotopias e devires diversos, entre eles o místico. Além disso, discorre-se sobre um de seus atos criminais, o estupro, como um ato abusivo sobre a soberania corporal do outro, algo que pode ser metaforizado através do ato de canibalismo. Neste capítulo, a bibliografia consultada fundamenta-se principalmente nos estudos de Rita Segato (2013), Michel Foucault (1984) e Erving Goffman (1961). Além disso, valemo-nos tambémde Serelle (2012) na questão da fetichização da cultura testemunhal; dos estudosdos gêneros romance negro e narrativa policial, feitos por Israel Lara (2012) e Nichols (2010); da pesquisa de Alterman Blay (2008) sobre assassinato de mulheres; dos posicionamentos de Haesbaert (2007) a respeito do conceito de território; e, finalmente, no que se refere à psicanálise criminal e à origem do ato delituoso, apresentam-se as pesquisas realizadas por Aguilera-Torrado (2010) e Melman (1992). 
Por último, o terceiro capítulo visa tratar da vida acadêmica de hispânicos nos Estados Unidos, indagando acerca da história de Michele e Fábian, uma ex- estudante de doutorado boliviana e um professor universitário argentino, ambos da área de estudos literários. Neste recorte, tratar-se-á das formas de funcionamentodo território acadêmico, materializado no espaço físico de seu campus, algo que o romance representa como afastado dos territórios exteriores a ele, bem como dos impactos de tal configuração territorial nos personagens que ali estão inseridos.

Em uma espécie de figuração dessa conflitiva relação do território acadêmico com o exterior, Michelle enquanto autora busca, por meio da escrita de comics $e$ releituras de contos consagrados pela crítica, efetuar uma nova possibilidade de literatura latino-americana em terras estadunidenses, rompendo com o estritamente canônico ao promover uma amálgama entre cultura pop e textos clássicos. Para este capítulo, utilizam-se os escritos de Glória Anzaldúa (1987), Fernando Ortiz (1940), Cornejo Polar (1994) e Ángel Rama (1982), sendo os três últimos trabalhados a partir da pesquisa de Sobrevilla (2011); a vontade de uma universalidade didática de Comênio (1657), com a qual comparamos o delírio do personagem Fabián de conceber uma teoria unificadora para a literatura latino-americana; os estudos sobre o gênero das campus nove/ ${ }^{4}$ implementadas por Showalter (2005), Moore-Martinez (2009) e Lynne Klein (2016); Zadie Smith (2000), que surge na epígrafe e em meio ao vasto corpus de campus novels consultadas; a visão de Eco (1979) ao tratar do leitor; Bertrand (2003), para as particularidades da narração de Michelle; Sayad (1998) por sua diferenciação para os termos imigrante e estrangeiro; além das contribuições de Rulfo (1976), Horacio González (2008) e Cortejoso de Andrés (2008), citando Bourdieu. Há, ainda, um extenso número de alusões a intelectuais e pesquisadores que de alguma forma são mencionados ao longo da linha narrativa em questão.

Dessa forma, o território e a fronteira surgem como recorte dessa pesquisa por se manifestarem como elementos fundamentais para o tratamento do simbólico no romance. A relação personagem-espaço é bem marcada em todas as linhas narrativas: no hospital psiquiátrico em que Martín está internado e em meio às lembranças de sua terra natal; no deambular de Jesús, o qual entra e sai de solo estadunidense com bastante facilidade, de modo que utiliza tal habilidade para a

${ }^{4} \mathrm{O}$ termo campus novel refere-se a obras cuja narrativa constrói-se em torno de campi universitários, diversas vezes tomando-os como elementos temáticos fundamentais para o desenvolvimento do enredo. 
prática criminal; e, no que se refere à Michelle, no campus universitário e seus arredores, que são trabalhados na obra como uma espécie de refúgio intelectual das complexas questões sociais vivenciadas em outras partes da cidade, mas que ali só chegam transmutadas em termos teóricos.

Além disso, Paz Soldán constrói sua obra de modo a transitar entre gêneros (sendo os mais evidentes: o romance negro, a narrativa policial e as campus novels, sem embargo trazendo também elementos oriundos dos comics, das graphic novels e das narrativas breves, tais quais os contos), o que nos leva a supor que seria uma estratégia de trazer para o aspecto formal, os deslocamentos e conflitos experienciados pelos personagens a nível temático, os quais podem ser interpretados como símbolo de latino-americanidade, mesmo que seus personagens se encontrem no hostil território estrangeiro.

Em outras palavras, trata-se de uma forma de trazer para a composição textual reflexões sócio-políticas importantes, como os processos de ressignificação simbólica pelos quais passa o sujeito imigrante. Isso se dá especialmente em relação àqueles que são migrantes de latino-americanos nos Estados Unidos, os quais estão em busca de maneiras de se reinventarem através da produção de seus discursos culturais, visando ler as problemáticas identitárias de modo a enfocá-las na questão do sujeito, antes que de uma ótica coletiva massificante. Há, com isso, a promoção de uma perspectiva que abarque a complexa situação migratória dos séculos $X X$ e XXI, gerada também por conta da condição econômica desigual, e facilitada pela criação de meios de transporte mais rápidos e eficazes, além de uma suposta globalização, que diversas vezes age de modo paradoxal ao menos conectar que excluir. 


\section{Capítulo 1. Martín: os territórios da fronteira}

Adotando como base inspiracional a vida do artista homônimo, a história do personagem Martín Ramírez desenrola-se no começo do século XX, época em que a construção de ferrovias é base para a fundação de novas cidades nos Estados Unidos, país para o qual imigra (sendo oriundo do país vizinho, México) com objetivo de obter um retorno financeiro imediato através do trabalho, principalmente na edificação das supracitadas ferrovias e no ramo de extração de minério. Todavia, o personagem tem sua trajetória bruscamente alterada ao ser internado, a partir do intermédio da polícia, em um hospital psiquiátrico, no qual passará o resto dos seus dias de vida, jamais retornando para sua nação natal. Nesse espaço, descobre na arte uma possibilidade de ferramenta para se comunicar e suportar o enclausuramento, tornando-se um artista reconhecido, ainda que, ao que tudo indica isso ocorreu de modo fortuito, já que não parece haver intenção por sua parte de se profissionalizar.

Para fins organizacionais, uma vez que o autor optou por utilizar o mesmo nome para ambos referentes, utilizaremos Ramírez para designarmos a figura histórica de Martín Ramírez e Martín para o personagem criado por Paz Soldán. Com isso buscamos possibilitar ao leitor deste trabalho uma delimitação mais clara no que diz respeito às menções e alusões.

É importante ressaltar que na obra Norte se busca ir além de uma biografia do artista, cuja trajetória Paz Soldán afirma utilizar apenas como base inspiradora, visto que o autor informa, em uma nota ao final do livro, que se trataria de uma "versión libre", orientada pela leitura do livro Martín Ramírez, editado por Brooke Davis Anderson (Marquand Books, 2007). Desse modo, o autor trabalha com o personagem de forma a romper o exclusivamente verídico (tal qual uma biografia), ainda que compactuando em retratar momentos emblemáticos da vida do pintor "real", como a imigração, o trabalho, a detenção em uma "instituição total", conforme o termo adotado por Goffman (1961) e a composição de suas obras de arte, as quais são inseridasno romance por meio da linguagem verbal, isto é, o narrador as descreve. 


\subsection{0 embate de representações em Martín Ramirez}

Diz um dos vereadores da cidade de Itaguaí, espaço em que se passa a obra O alienista, de Machado de Assis: "Nada tenho que ver com a ciência; mas, se tantos homens em quem supomos são reclusos por dementes, quem nos afirma que o alienado não é o alienista?" (ASSIS, 1882, p. 32).

Diferentemente do que ocorre com as doenças que acometem a corporalidade dos indivíduos, as enfermidades mentais entram no campo da psiquê humana, cuja imaterialidade e subjetividade faz com se torne mais difícil delimitar tal fenômeno. Consequentemente, a situação relatada na obra acima, em que se constrói um asilo para a internação de pessoas consideradas alienadas, o qual acaba em certo ponto por compreender quatro quintos da população local, é adequada por demonstrar que a loucura traz em si uma fronteira inegável, com frequência abstrusa: o limiar entre o que se espera de um sujeito mentalmente saudável e aquilo que seria próprio de uma pessoa enlouquecida.

Essa reflexão vem com o objetivo de abrir espaço para que tracemos questionamentos a respeito da construção dos traços de insanidade no personagem Martín, pensando também na condição do artista que serviu de inspiração para sua criação. Afinal, há em ambos os casos contextos sócio-espaciais complexos nos quais eles se inserem (ou são arbitrariamente inseridos) durante suas trajetórias, sejam eles efetuados de forma material, isto é, fisicamente, ou por meio do recurso da memória.

Em seus estudos sobre o tema da insanidade no livro O que é loucura, o psicanalista e professor João Frayze-Pereira empreende uma investigação em torno dos possíveis sentidos que o termo loucura pode carregar, bem como os impactos que ele ocasionaria no indivíduo que recebe tal rotulação, lembrando-nos que setrata antes de tudo, de algo que concerne não apenas ao indivíduo, mas também havendo toda uma construção social imbricada. Segundo afirma Frayze-Pereira, "há limites para a expressão da loucura. E isto significa que a loucura é uma criação cultural". (FRAYZE-PEREIRA, 1985, p. 29).

Foucault, por sua vez, em sua abordagem do tema, disserta em sua obra História da loucura na idade clássica acerca do difuso limiar que se estabelece muitas vezes entre o processo de institucionalização da pessoa vista como insana, com o objetivo de tratá-la, e o enclausuramento compulsório de qualquer um que ousasse não se comportar conforme ditam as normas sociais, aquele que deveria ser isolado 
para se evitar a disseminação de tais posturas, bem como manter o objetivo de proteger a sociedade de um suposto mal. O "louco" estaria, desse modo, frequentemente em oposição a um "normal" que é fruto de uma concepção restritamente socializante, que por sua vez, compreende que a loucura deve ser tratada exclusivamente do ponto de vista científico. Nesta perspectiva, manifesta-se a medicalização e internação do sujeito desviante. Assim, despojam-no não apenas de sua experiência social, mas também de sua constituição enquanto ser jurídico, de modo que a supressão de seus direitos seja justificada pela possível alienação:

Tudo isso é de extrema importância para o desenvolvimento ulterior da medicina do espírito. Esta, em sua forma "positiva", é no fundo apenas a superposição de duas experiências que o Classicismo justapôs sem nunca reuni-las definitivamente: uma experiência social, normativa e dicotômica da loucura, que gira ao redor do imperativo do internamento e se formula apenas em termos de "sim ou não", "inofensivo ou perigoso", "para ser internado ou não"; e uma experiência jurídica, qualitativa, finamente diferenciada, sensível às questões de limites e gradações e que procura em todos os setores da atividade do sujeito os rostos polimorfos que a alienação pode assumir. A psicopatologia do século XIX (e talvez ainda a nossa) acredita situar-se e tomar suas medidas com referência num homo natura ou num homem normal considerado como dado anterior a toda experiência da doença.Na verdade, esse homem normal é uma criação. E se é preciso situá-lo, nãoé num espaço natural, mas num sistema que identifique o socius ao sujeito de direito; e, por conseguinte, o louco não é reconhecido como tal pelo fato de a doença tê-lo afastado para as margens do normal, mas sim porque nossa cultura situou-o no ponto de encontro entre o decreto social do internamento e o conhecimento jurídico que discerne a capacidade dos sujeitos de direito. A ciência "positiva" das doenças mentais e esses sentimentos humanitários que promoveram o louco à categoria de ser humano só foram possíveis uma vez solidamente estabelecida essa síntese. De algum modo ela constitui o a priori concreto de toda a nossa psicopatologia com pretensões científicas. (FOUCAULT, 1997, p.133).

Dessa forma, no célebre livro, Foucault traça a História da Loucura desde a sociedade medieval até o surgimento dos asilos para alienados no século XVIII e explica a transição destes para os hospitais psiquiátricos da atualidade, sendo que o termo alienado foi engendrado justamente com o objetivo de retratar o julgamento de que tais pessoas não teriam condições racionais para pertencerem à sociedade de forma crítica e participativa, o que acaba por promover um movimento de dessocialização do indivíduo cujos comportamentos podem ser interpretados como diversificados, logo, insanos, do mesmo modo que aconteceu com Ramírez.

Daí surge a importância, segundo esse ponto de vista, de que tais pessoas sejam isoladas da sociedade e ingressadas em ambientes em que os demais sujeitos sejam de característica similar, nos quais se formulam outras especificidades, para além da lógica social exterior a elas. Goffman (1961), ao pesquisar tais espaços, os denomina instituições totais. Neles, a predisposição básica dos indivíduos no "mundo 
exterior" que seria a de "dormir, brincar e trabalhar" em locais distintos passa a centralizar-se de forma que já não há mais distinção espacial entre tais atividades da vida humana. Além disso, há também a frequente supervisão de "uma única autoridade"e "a presença constante de um grupo relativamente grande de outras pessoas, todaselas tratadas da mesma forma e abrigadas a fazer as mesmas coisas em conjunto", sempre respeitando horários rígidos já previamente estabelecidos (GOFFMAN, 1961, p. 17-18). Finalmente, o sociólogo explica que as instituições totais têm como regra geral o impedimento do livre deslocamento daqueles que ali estão detidos quase sempre expressado por obstruções materiais:

Seu "fechamento" ou seu caráter total é simbolizado pela barreira à relação social com o mundo externo e por proibições à saída que muitas vezes estão incluídas no esquema físico - por exemplo, portas fechadas, paredes altas, arame farpado, fossos, água, florestas ou pântanos. (GOFFMAN, 161,p. 18).

Ocorre, assim, que a coerção social em prol da normatização é efetivada e ratificada através do corpo dirigente do hospital psiquiátrico, sendo o médico psiquiatra a figura principal, cujo poder determina não somente o reconhecimento da possível insanidade, como também a qual categoria o sujeito analisado estaria subscrito, traçando desde já seu destino. Tudo isso é feito, frequentemente, a partir da constante deslegitimação das razões que estariam por trás dos atos e falas das pessoas em condição de pacientes 5 .

Se a identificação e a delimitação do fenômeno de loucura dependem, portanto, quase que exclusivamente do quadro sintomático apresentado por aquele que dela padeceria (visto que não é possível saber com exatidão o que se passa no íntimo de cada indivíduo), este, por sua vez, está sujeito ao jugo da sociedade, que delimita quais comportamentos podem ser considerados saudáveis e quais não seriam. Desse modo, cada comunidade terá formas diversificadas de lidar, de acordo com a conjuntura em vigor, com aqueles que a comunidade considera como insanos.

O caso de Ramírez não poderia ser diferente. Vítima ou não de racismo institucional, caso sobre o qual discorreremos a seguir, o que ficou claro durante nossos estudos é que sua posição de outsider já estava forjada desde o momento em

\footnotetext{
${ }^{5}$ Frayze-Pereira explica: "O psiquiatra fala de sintomas mentais ao se referir às comunicações do paciente consigo próprio, com os outros e com o mundo que o rodeia. O paciente pode afirmar que éo novo Messias, que viu discos voadores ou que está sendo perseguido pelos marcianos. Essas afirmações seriam consideradas sintomas de doença mental apenas se o observador não acreditar no paciente ou na viabilidade do que diz ter-Ihe ocorrido." (FRAYZE-PEREIRA, 1985, p.29).
} 
que cruza a fronteira geográfica que separa o "irmão rico" do "irmão pobre".

Fotografia 1 - Fotografia de Martín Ramírez segurando um de seus quadros.

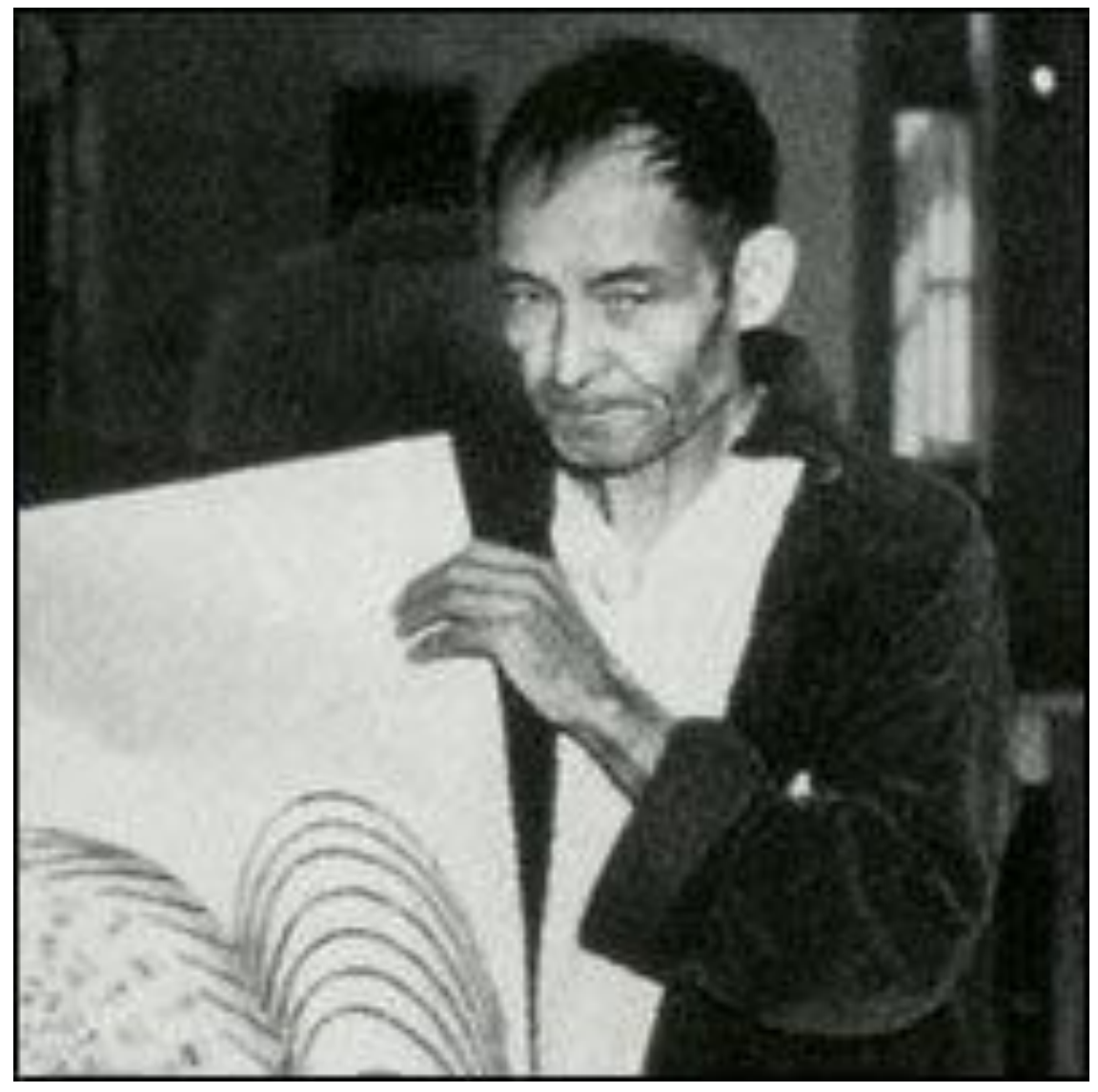

NPR ${ }^{6}$. Martín Ramirez.no Hospital DeWitt State na Califórnia, 1950.

Durante o período de auge da economia estadunidense, que se sucedeu após o fim da Primeira Guerra Mundial, Ramírez, cidadão mexicano, imigra para o país ao norte em busca de uma fonte de renda que lhe permitisse o quitamento de dívidas feitas após a compra de um terreno para a residência e subsistência de sua família na região de Altos de Jalisco, localizada no centro-oeste do México. Após trabalhar arduamente na construção de estradas ferroviárias e na exploração de minério, tendo frequentemente companheiros de trabalho e chefes compatriotas também imigrantes, ele acaba tornando-se mais um dos vários mexicanos que passaram à situação de rua, padecentes da Grande Depressão que assola os Estados Unidos na segunda década do século XX, a qual tem seu momento de ápice no ano de 1929.

\footnotetext{
${ }^{6}$ Fonte:<https://www.npr.org/templates/story/story.php?storyld=96004813>. No site em que a imagem foi extraída está presente a seguinte nota ao pé da fotografia: "Martín Ramirez spent more than 30 years in California psychiatric hospitals. He is pictured above at DeWitt State Hospital in Auburn, Calif.around $1950 "$.
} 
Dadas as condições, apesar de ser uma solução mais imediata e provável que essas pessoas regressassem ao seu país de origem, havia um grave impedimento que as impelia a manter-se em solo estrangeiro: no outro lado da fronteira,em solo mexicano, estava transcorrendo a Guerra Cristera, ocorrida entre os anos 1926 e 1929, mas cujas consequências econômicas e políticas estenderam-se por muito mais tempo que apenas os três anos de sua duração. Assim, uma multidão de imigrantes acaba por vagar sem rumo pela nação estadunidense nesse ínterim, de forma que o deslocamento que deveria ser, quase sempre, momentâneo para tais pessoas (apenas para conseguir uma quantia suficiente de dinheiro que garantisse uma melhor condição financeira para a família) torna-se permanente, fazendo com que os impactos do afastamento do território de nascença, do seio familiar e da própria cultura, sejam duramente sofridos.

Nesse contexto, Ramírez, sem casa nem emprego, foi detido por policiais que, sem sucesso, insistiram em estabelecer comunicação em inglês, desconsiderando seu conhecimento bastante limitado do idioma, bem como a proporção de seu abalo emocional e o choque cultural sofrido ocasionados, entre outros motivos, pelo contraste entre a moderna Califórnia e sua modesta e rural Jalisco natal, além dos impactos oriundos da vida nas ruas por conta de sua condição de desempregado e desabrigado. Por isso, ele é conduzido a um hospital psiquiátrico, permanecendo internado pelos próximos 32 anos, até sua morte em 1963, sob a prescrição médica de esquizofrenia ("dementia praecox, catatonic form"), dada no ano de 1933 .

O diagnóstico recebido por Ramírez, todavia, tem sido extensamente questionado por alguns estudiosos de sua vida e obra, os quais o refutam com a suposição de que o artista possivelmente teria sido, na verdade, vítima de um ato de racismo institucional, provocado principalmente pelas diferenças culturais entre o imigrante mexicano e os médicos californianos. Espinosa (2015) traça em seu livro Martín Ramírez: Framing His Life and Arta a seguinte descrição a respeito do momento emque sua suposta doença é diagnosticada:

After Ramírez was "dismissed", Marnell declared him to be a case of "dementia praecox." All the rest of the doctors present, apparently without any discussion, approved the diagnosis by a unanimous vote. Then Conzelmann made the official clinical diagnosis: "dementia praecox, catatonic form." In those years, dementia praecox was one of the most common diagnoses in

${ }^{7}$ ESPINOSA, 2015, p. 69. 
state institutions. A 1932 manual describes a patient with dementia praecox as being mainly characterized by "peculiar trends, often fantastic ideas, with odd, impulsive, or negative conduct". The label "catatonia", a subtype of dementia praecox, was applied to any patient "who may be negativistic or mute". Today the same diagnosis is more often combined with mood disorders, especially maniac-depressive illness. Once placed upon a patient in the psychiatric health system, diagnosis labels are very difficult to shed, even when they have been applied inaccurately of mistakenly. In those years, it was even more difficult to chance such a diagnosis. With very little hope of "recovery" and no relatives present to fight for him, Ramírez was essentially condemned to die inside the hospital.(ESPINOSA, 2015, p. 69).

Ainda no que se refere à possibilidade de que seu diagnóstico tenha sido equivocado, Espinosa segue traçando elementos fundamentais sobre a relação entre o encarceramento em hospitais psiquiátricos e a condição de Ramírez enquanto imigrante mexicano:

The only evidence we have about his emotional condition is his medical file, which besides being produced from the perspective of the people who deprived him of his liberty, reveals the social, cultural and psychological barriers that existed between Ramirez and the doctors who examined and interrogated him. The transcripts of his interrogations during the two clinical conferences indicate that his psychological state was evaluated under arbitrary conditions in a social context that included cultural and language barriers as well as prevalent racism against Mexicans and immigrants in general. Today, his medical file could be used as evidence to argue that Ramírez's diagnosis should have been different. But the accuracy of the diagnosis will remain open to debate, since it is too late to know what Ramirez's emotional or psychological condition was when he was picked up by the police in Stockton in a state of mental confusion. It is also too late to look for an organic or psychological explanation of the causes of his possible mental illness. Whatever the accuracy of his diagnosis at the moment of his detention, there is a second problem: it is probably impossible at this time to evaluate to wear degree his forced seclusion in two psychiatric hospitals for more than thirty-two years affected his baseline psychological condition. Ramirez's diagnosis stuck to him, influencing the contradictory process of inclusion and exclusion that have marked the reception and recognition of his artwork. But without ignoring the difficult circumstances that immigrant patients faced inside psychiatric hospitals, what sort of historical, social, and cultural conditions facilitated both Ramirez's intense dedication to drawing and the preservation of his large body of work? (ESPINOSA, 2015, p. 80).

Sabendo da possibilidade de que haja um erro no diagnóstico dado a Ramírez, bem como da estreita ligação que se dá entre sociedade e construção identitáriado sujeito psiquiatricamente diagnosticado como doente mental, além do fato de que Paz Soldán tenha escolhido como objeto de sua ficcionalização um caso complexo de imigração e possível loucura, leva-nos a perguntar como essa dupla condição é representada no romance ou, em outras palavras, como isso é aproveitado esteticamente para a construção do romance como um todo, especialmente (mas não somente) nos capítulos dedicados ao personagem Martín Ramírez.

$\mathrm{Na}$ narrativa em questão, são construídas as complexidades da intimidade de Martín por meio da mediação de um narrador onisciente em terceira pessoa um tanto 
quanto particular, que diversas vezes cede seu espaço para que, através do discurso indireto-livre, o personagem consiga expressar-se. De acordo com o que afirma o pesquisador espanhol Mario Martín Guijón (2011), em seus estudos sobre o romance Norte, tratar-se-ia do uso da psico-narração:

\begin{abstract}
[...] el autor recurre a la psico-narración (donde, según la narratóloga Dorrit Cohon, se combinan la voz del narrador y la del personaje para llegar a elucidar, en lugar de reflejar, el funcionamiento de la mente del protagonista) en los capítulos ocupados por Jesús González y Martín Ramírez, dos hombres desplazados cuyas historias, en apariencia tan diferentes, comparten elementos que ascienden del nivel de la anécdota a símbolos. Así, los dos abandonaron una edad feliz al otro lado de la frontera, exiliándose también de la única mujer a la que amaron, y en ambosel ferrocarril sirvió como desencadenante de suas viajes a la locura en el país ancho y ajeno. (MARTÍN GUIJÓN, 2011, p. 164).
\end{abstract}

Surge, assim, no plano estrutural do romance, a memória e as reflexões do personagem como elementos básicos para a construção de sua linha narrativa, ocorrendo constantemente uma sobreposição de temporalidades e espacialidades nas quais presente e passado, lá e aqui, são frequentemente expostos simultaneamente ao leitor por meio de um narrador cuja onisciência é seletiva, afinal conhece e compactua apenas com os pensamentos do personagem principal. Desse modo, é proposta uma espécie insipiente de fluxo de consciência, fazendo com que esse narrador atue fundamentalmente como um mediador.

Utilizando-se desse narrador sui generis, há no romance alguns momentos nos quais se torna possível o questionamento acerca do verdadeiro estado mental do personagem, ainda que sua suposta loucura nunca seja questionada explicitamente, tampouco é dada como óbvia. Trata-se exclusivamente do ponto de vista de Martín sobre si mesmo e em momento algum ele se vê como uma pessoa insana. À vista disso, uma das poucas marcas nas quais se poderia perceber que a representação do personagem é dúbia no que diz respeito à suposta loucura trata-se justamente de ele demonstrar não conseguir compreender seu diagnóstico, afinal nunca Ihe haviam explicado que significavam aquelas quatro palavras (dementia praecox, catatonic form) que o marcariam por todo o resto de sua vida, e por conta disso, a ele é negada a possibilidade de contestá-lo: "Semanas después el señor Walker pronunció su veredicto delante de otros doctores y Martín: dementia praecox, catatonic form. Martín no entendió nada." (PAZ-SOLDÁN, 2011, p. 76).

Desse modo, tal incompreensão acaba por reforçar a ideia de que Martín teria uma noção distorcida dos motivos pelos quais ele estaria confinado naquele espaço tão totalitário. O personagem acredita ser um prisioneiro de guerra, o que apesar de 
parecer insano (reforçando a ideia da esquizofrenia), possui uma fundamentação sólida, uma vez que o personagem havia recebido uma carta de seu irmão, Atanacio, em que Ihe dizia para não regressar ao México, dado que o país estava naquele momento passando pela já mencionada Guerra Cristera. Além disso, seu modo de interpretar a espacialidade em que o haviam inserido pode ser ratificada a partir do posicionamento de que tanto os campos para prisioneiros de guerra, quanto os hospitais psiquiátricos seriam, para Goffman, instituições totais, tendo processos de ingresso bastante similares. Nesses momentos, a equipe responsável pela admissão tem características habituais próprias a ambos os espaços "obter urna história de vida, tirar fotografia, pesar, tirar impressões digitais, atribuir números, procurar e enumerar bens pessoais para que sejam guardados", além de "despir, darbanho, desinfetar, cortar os cabelos, distribuir roupas da instituição, dar instruções quanto a regras, designar um local para o internado" (GOFFMAN, 1961, p. 25-26).

Nota-se também que, em outro momento da narrativa, quando utilizam o termo "loco", dessa vez em espanhol, isto é, de forma que ele pudesse compreender, para se referir ao personagem verifica-se a quebra do pacto de silêncio que havia feito até então (Martín havia escolhido não se comunicar mediante via oral, possivelmente como forma de resistência e até mesmo de autoproteção, mas também muito provavelmente por seu pouco conhecimento da língua inglesa), em uma resposta efusiva de que não estaria louco ${ }^{8}$.

De outra parte temos a construção da loucura no personagem por meio de comportamentos e pensamentos excêntricos, que são mostrados ao leitor através da onisciência seletiva. Assim, é possível encontrar em suas interpretações da realidade, divagações e conduta amostras de sintomas considerados socialmente desviantes, portanto, insanos. Provavelmente o exemplo mais icônico e plausível da composição da insanidade do personagem está em Martín julgar possuir um superpoder, assim como ocorre com outros pacientes do hospital psiquiátrico no qual está internado. Para ele, algo comum como o fechar dos olhos fazer com que tudo ao redor desapareça era, na verdade, um dom divino e exclusivo:

El hombre de la capa repetía Ai am a jiro, y Martín se preguntaba qué significaba jiro. El de la silla de ruedas gritaba Mai esprai uil meik yu invisibol. Eso podía entender, pero el aerosol rociaba a la gente y nadie se volvía invisible.

Martín, en cambio, podía cerrar los ojos y hacerlos desaparecer.

\footnotetext{
8 "Martín se animó a decir: ¿Locos? Él no estaba loco." (PAZ-SOLDÁN, 2001, p. 178).
} 
Cuando venía uno de los enfermeros a llevárselo a una sala donde un doctor lo conectaba a unos cables, él se concentraba y el doctor desaparecía. La electricidad lo golpeaba y él trataba de que el dolor no existiera pero eso era imposible. (PAZ-SOLDÁN, 2011, p. 141-142).

Por conta disso, em sua interpretação dos acontecimentos, tal artifício o dotaria de uma grande potência e, portanto, ele deveria ser utilizado com cautela, uma vez que já lhe havia passado de que, ao abrir novamente os olhos, não estivessem todos os elementos iniciais de volta à sua frente: "Tenía que ser cuidadoso, aprendera utilizar lo que el Señor le había dado. Perfeccionar la técnica, de modo que todos volvieran o ninguno, no era bueno separar a la gente, que unos se quedaran allí $y$ otros aquî". (PAZ-SOLDÁN, 2011, p. 40).

Desse modo, podemos perceber que o "poder" de Martín lhe provoca o medo de que ele possa se converter no ocasionador do doloroso movimento de separação entre pessoas, o que tem relação com sua penosa trajetória de isolamento familiar e social. De acordo com ele, não restam dúvidas: pessoas não deveriam ser separadas daquelas de seu convívio. Por conta disso, no momento mencionado, temos uma demonstração de como o personagem pensa e sente seu mundo cindido através de sua avaliação sobre como deveria ser usado o "poder" que possui, propondo, aparentemente, mais uma reflexão amedrontada sobre si mesmo, suas experiências de vida e a situação de afastamento em que estava inserido do que um receio sobre o destino dos possíveis indivíduos que seriam alvo da dita separação.

A construção do personagem Martín se dá em meio a essa difusão de papéis, os quais se superpõem para formar uma figura maior, cuja amplitude não se restringe aos limites designados. Assim como seus desenhos e pinturas que tentam escapar da tela através de linhas paralelas, ele rompe com a realidade imposta e traz todos esses seres em um só. Daí que surge também a importância de situá-lo espacialmente.

O hospital psiquiátrico tratar-se-ia, de acordo com Goffman, de um local alienante, do qual aqueles que ali estão internados jamais conseguem apropriar-se de fato, afinal sua estrutura é baseada, fundamentalmente, em isolar o sujeito considerado louco da sociedade e da vida em família, o que resulta na criação de um microcosmos de não pertencimento. Tal característica é o que nos leva à hipótese de que Martín, imerso em tal ambiente hermético, busca como modo de escape suas formas artísticas. Suas pinturas, collages e desenhos, repletos de temas comuns, serão discutidos na próxima seção. 


\subsection{A arte psiquiátrica como ferramenta de reterritorialização}

O fazer artístico de indivíduos que estão em condições semelhantes de produção a Martín, isto é, confinados em instituições psiquiátricas, tem como tendência caracterizante o fato da transformação em símbolo, própria da arte, dar-se através de uma expressão quase que exclusivamente individual, muitas vezes autodidata, e até mesmo por meio de uma manifestação do inconsciente do artista. É dessa forma que o modus operandi de sua composição se opõe à ideia de instrução prévia comum aos artistas convencionais, uma vez que a arte destes é confeccionada por intermédio de toda uma gama de conhecimentos baseados em investigações anteriores ao momento de produção acerca do processo de se fazer arte, como o estudo de técnicas e temas.

Um exemplo dessa dicotomia no romance estudado é a relação que os personagens Martín e Michelle têm com suas artes, já que o ponto de partida do qual originam suas produções é bastante diverso: a loucura de Martín criaria uma espécie de diário do que se passa em seu mundo interior, destacando-se seu caráter autodidata. Michelle, por outro lado, o faz de forma instruída e consciente, a partir do estudo minucioso de obras, vertentes e técnicas, produzindo releituras e demonstrando grande conhecimento acumulado das criações de outros artistas (sejam elas canônicas ou não, afinal a personagem possui preferência por comics e elementos da cultura pop), sendo possível ver esse embasamento investigativo na releitura do conto Luvina, apresentado na quinta parte do romance.

Tratam-se, portanto, de processos de composição essencialmente distintos. De acordo com Franco (2011), cada uma dessas formas de arte é frequentemente vista, em sua substância final, de modo que a feita por Martín teria valor puramente estético enquanto que a feita por Michele possuiria valor artístico, dado o processo de racionalização pelo qual passou antes de chegar ao resultado final:

A diferenciação entre capacidade de produção com valor artístico e capacidade de produção com valor "estético" parece clara nestes autores a primeira é aquela que emana da racionalidade e, com isso, consegue correlacionar em sua obra características formais inovadoras e funcionalidade social; a segunda é a capacidade universal existente em todo homem, que cria formas, muitas vezes belas e interessantes, mas que por sua irracionalidade não se constitui no quadro de alcances intelectuais. $O$ mundo fantástico em que vive o esquizofrênico ou o demente possui a mesma origem da simbologia empregada pelos artistas, que conseguem mergulhar com facilidade no pensamento e no sonho, criando imagens 
oníricas e irreais. [...] A questão que parece ficar clara é que a obra produzida pelo alienado poderia, sim, figurar como "arte" mas, o louco por sua incapacidade intelectual, não poderia figurar como "artista". (FRANCO, 2011, p. 77).

Isto posto, buscando uma melhor forma de definir a arte feita por pessoas classificadas como loucas ou anormais, surgiram ao longo do século XX vários conceitos, entre eles estando os de "Art Brut", "Art Naïf" e, sobre o qual discorre Andriolo, "Arte Incomum":

\begin{abstract}
Em 1989, o termo Arte Incomum figura no compêndio de artes visuais elaborado por Frederico Morais, dando-lhe o devido crédito como categoria artística; uma tradução do francês Art Brut, ocupando o "espaço impreciso entre a arte popular e a arte erudita" (Morais, 1989, p.80). No entanto, observando em retrospectiva os eventos que se seguiram à exposição de 1981, vemos que este conceito não se sustentou por muito tempo na intelectualidade brasileira. Ao contrário do campo formado em torno dos naïfs, nos escritos sobre artes, a utilização do termo Arte Incomum rareia. (ANDRIOLO, 2004, p. 28).
\end{abstract}

Ocorre, assim, que a multiplicidade de acepções citada tentam enquadrar um campo de produção artística diverso ao convencional, sendo que nem sempre é possível delimitar uma provável vertente a cada artista inserido nessa categoria (como dito acima, muitos são autodidatas e não seguem estéticas específicas). Dessa forma, em tais artistas podem-se perceber tão somente alguns traços em comum com esta ou aquela vertente, bem como entre si. Neste caso, a associação mais frequente é com a estreita relação que a produção oriunda desse modo artístico estabelece com o inconsciente e a individualidade de cada um de seus artistas, sendo muitas vezes interpretada como um jorro de imagens interiores, no qual haveria pouco ou nada de raciocínio consciente mediador.

Dubuffet, pintor francês e um dos precursores da Arte Bruta, discorre em seu ensaio Asphyxiante culture (1986) sobre a importância de que haja não apenas uma reforma no cânone artístico e naqueles que selecionam quais obras e autores seriam suficientemente relevantes para ingressá-lo, mas em toda a construção de cultura que se tem no ocidente, a qual "musealiza" a arte, afirmando que esta só existiriae só seria, de fato, arte sempre e quando ela estiver exposta em um museu.

Como resistência a isso e à própria noção de valor que se origina dessa concepção de $a^{2}{ }^{9}$, o pintor ressalta que deveria se buscar fundamentalmente a criação e inovação "asfixiadas" pela mercadologização cultural das obras de arte, bem

9 Uma vez que a concepção de arte restrita à sua exposição em museus ou a uma possível monetarização pressupõe a existência de graus de valoração, nos quais um determinado objeto artístico seria "melhor", isto é, mais valioso do que outro. 
como de seus artistas. Desse modo, para ele, a arte feita por pessoas julgadas loucas, queé vista frequentemente como sem valor para além do funcional, isto é, servindo para auxiliar o diagnóstico médico ou como instrumento para tratamento, seria a verdadeira forma artística, já que além derivar do mais puro individual, seria livre das amarras do utilitarismo. É possível concluir, por fim, que ainda que isso seja feito de modo indireto, Dubuffet propõe uma inversão estrutural: seriam justamente os homens sãos aqueles que deveriam se inspirar nas produções artísticas dos ditos alienados e não o contrário, como muitas vezes se faz parecer em uma cultura na qual se prega sobretudo o excesso de organização por meio do predomínio da razão e da catalogação frenética.

A arte Martín traz esse outro lado, uma vez que o objetivo deste não parece ser produzir formas artísticas dotadas da ideia de valor canônico, tampouco expor em galerias e museus (ainda que o faça por conta do intermédio de Tarmo Pasto, o qual estabelece o papel de mediador entre o personagem e o circuito artístico, externo ao âmbito hermético do hospital psiquiátrico). Sua arte seria, com base nisso, uma de suas maneiras de lidar com uma espécie de mergulho interior, sendo seu "eu", tão caro da individualidade exaltada por Dubuffet, extremado em uma interioridade que se reflete na corrompida pela possível insânia e pelo afastamento espacial e temporal, o qual o faz viver simultaneamente no passado e no presente e fechar-se ao convívio com as demais pessoas. O contato com o "eles" é evitado ao máximo, com exceção apenas de um professor que lhe faz visitas e se interessa por sua arte e de uma breve amizade com outro interno, que pouco depois morre.

Agravando a situação de isolamento na qual está inserido, uma vez que segundo Goffman, o mundo das instituições fechadas se sustenta a partir da alienação do sujeito a tudo que se constrói em seu exterior, há também um bloqueio do personagem em relação ao comunicar-se por meio da via oral: "Cuando se reunía con ellos en las salas o en el jardín, se esforzaba por hablar, pero apenas le salían balbuceos guturales. Entonces reía." (PAZ-SOLDÁN, 2011, p.141).

Assim, a supressão de sua voz é uma das principais marcas da quebra de seu lugar na sociedade, uma vez que a articulação do signo linguístico trata-se de um dos elementos básicos, não apenas para o convívio social, como também para a autoconstituição territorial dos sujeitos. Frayze-Pereira (1985) explica melhor sobre a construção da espacialidade para o indivíduo visto como insano do seguinte modo: "Circulante entre espaços que não são seus, o louco encontra-se emtoda parte e em 
nenhuma. Figuras importantes por sua ambiguidade, a loucura e o louco ameaçam e surpreendem o mundo." (FRAYZE-PEREIRA, 1985, p. 52).

No primeiro capítulo de História da loucura na idade clássica, Foucault trabalha extensivamente com a representação da "nau dos loucos" (ou Narrenschiff, ou Stultifera Navis), de modo a retratá-las por sua importância simbólica no contexto histórico da Renascença. Partindo dessa mesma ideia, podemos pensar como um correlato contemporâneo à figura do trem, a qual surge como ferramenta para o deslocamento de pessoas, inclusive daqueles julgados insanos ${ }^{10}$. Um exemplo disso está em Guimarães Rosa, cujo conto Sorôco, sua mãe, sua filha traça um cenário em que os trens são utilizados de forma bastante similar à "nave dos loucos".

A obsessão de Ramírez pelos trens parece, com isso, remeter a uma figura um tanto quanto significativa para o imaginário psiquiátrico: as naus, bastante presentes nos trabalhos de outros artistas também provenientes de instituições asilares, como Bispo do Rosário, Ivan Grilo, José Leonilson, Luiz Carlos Marques, Arlindo Oliveira, dentre vários. Talvez seja por essa relação entre trens e naus que tenha sido escolhida a ilustração de um navio desenhado por Ramírez para compor a capade um dos diversos livros em que se reúnem suas obras finais:

\footnotetext{
${ }^{10}$ Assim como as naus, os trens não têm como função original o deslocamento de pessoas julgadas como insanas, ainda que tais meios de transporte tenham sido utilizados historicamente com essa função. Neste caso, o objetivo não é conectar periferia e centro, mas promover o caminho inverso: buscase isolar, relegar à margem. Em ambos os casos a finalidade de deslocar pessoas consideradas alienadas é a mesma: o afastamento aos olhos dos considerados sãos, sendo que, no segundo caso, isso se dá através do subjugo ao controle estatal.
} 
Ilustração 1 - capa do livro The last works. ${ }^{11}$

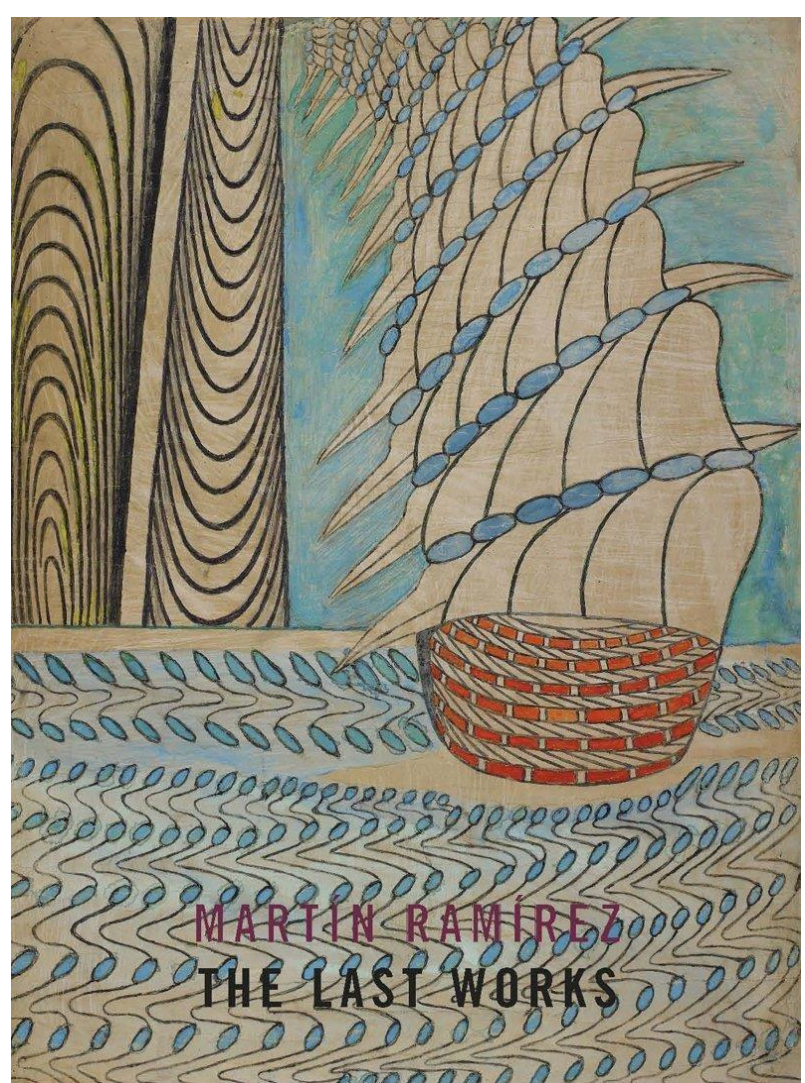

Fonte: (editora). Desenho de Martin Ramirez, Sem título (Galeão na água), c.1960-63, guache, lápis de cor e grafite sobre papel, $83 \times 60 \mathrm{~cm}$.

A figura do trem como meio de transporte de pessoas julgadas insanas é vista, no contexto brasileiro, com grande importância no livro Holocausto brasileiro, de Daniela Arbex (2019), em que a jornalista explica sobre o papel fundamental que tiveram as locomotivas que traziam pessoas de todas as partes do Brasil e as entregavam nas mãos daqueles que deveriam ser seus cuidadores, mas que acabavam por tornarem-se seus algozes:

A parada na estação Bias Fortes era a última da longa viagem de trem que cortava o interior do país. Quando a locomotiva desacelerava, já nos fundos do Hospital Colônia, os passageiros se agitavam. Acuados e famintos, esperavam a ordem dos guardas para descer, seguindo em fila indiana na direção do desconhecido. Muitos nem sequer sabiam em que cidade tinham desembarcado ou mesmo o motivo pelo qual foram despachados para aquele lugar.

\footnotetext{
11 Fonte:<https://folkartmuseum.org/exhibitions/martin-ramirez-the-last-works/>. No site em que a imagem da obra se encontra disponível está presente a seguinte nota ao pé da fotografia do desenho: "Untitled (Galleon on Water) Martín Ramírez (1895-1963) Auburn, California c. 1960-1963 Gouache, colored pencil, and pencil on pieced paper $33 \times 24$ in. Collection of Audrey B. Heckler@ Estate of Martín Ramírez; photo by Ellen McDermott, New York". O livro, por sua vez, está disponível em:<https://www.amazon.com/Martin-Ramirez-Last-Works-Notecard/dp/1584181435>.
} 
Os deserdados sociais chegavam a Barbacena de vários cantos do Brasil. Eles abarrotavam os vagões de carga de maneira idêntica aos judeus levados, durante a Segunda Guerra Mundial, para os campos de concentração nazistas de Auschwitz. A expressão "trem de doido" surgiu ali. Criada pelo escritor Guimarães Rosa, ela foi incorporada ao vocabulário dos mineiros para definir algo positivo, mas, à época, marcava o início de uma viagem sem volta ao inferno. (ARBEX, 2019, p. 23).

O "Colônia", hospital psiquiátrico situado na cidade mineira de Barbacena e retratado no livro de Arbex, tinha como prática o tratamento sub-humano de seus internos, privando-os das condições básicas de alimentação, segurança e higiene, além de fazerem uso indiscriminado do tratamento via eletrochoque, o qual também é utilizado em Martín, e bastante condenado pelo movimento de luta antimanicomial que ganhou força no final do século passado.

Desse modo, os mesmos trens que fascinam Martín e através de cujos desenhos (uma vez que se trata de uma temática recorrente em suas obras) consegue empreender seu escape, com os quais desloca-se em locomotivas imaginárias, feitas de papel, são também aqueles que o levaram aos Estados Unidos e, consequentemente, à sua internação. Lembrando que há ainda, nesse caso, o fato de ele próprio ter ajudado a construir a malha ferroviária para que o trem, que é um "emplazamiento de pasaje", segundo a terminologia adotada por Foucault (1967, p.2), seja consolidado em terras estadunidenses e possa, cada vez mais, transferir pessoas deum ponto a outro. Com isso, retomamos como se ele próprio tivesse facilitado, ainda que de forma inconsciente e indireta, seu ingresso na instituição psiquiátrica, uma vez que é por meio do trem que ele adentra terras estadunidenses e é após ser acometido por um surto em uma estação ferroviária que a polícia o detém.

Trata-se, portanto, de uma situação restrita a seu caso particular, afinal não há menção no romance sobre o uso dos trens para levar pessoas a um manicômio como ocorre no caso brasileiro, de modo que apenas Martín é levado e isso é feito indiretamente.

Apesar da estrutura linear da narrativa, a arte de Martín aparece implícita no romance mesmo antes que sua atividade artística seja reconhecida como tal,uma vez que já desde o primeiro capítulo de sua narrativa é possível perceber referências aos lugares-comuns das obras de arte do personagem por meio do modo como narrador integra os pensamentos do personagem à narrativa, retratando a 
forma de ver o mundo de Martín. É desse modo que se dá o início da construção do personagem como artista: evidenciando que ele já possuía um "olhar artístico" antes mesmo de entabular no ofício da produção de arte e elaboração de quadros.

Um exemplo de tal modo de ver e interpretar o mundo está representado nas duas primeiras páginas da parte referente a Martín, nas quais o narrador efetua digressões na linha narrativa para, como vimos acima, ceder espaço ao olhar do personagem. É a partir dessa estratégia narrativa que percebemos que Martín, ao deparar-se com um simples quiosco, no qual são vendidos revistas e jornais, começa a formar em sua mente ideias nas quais se constrói uma espécie de collage, como aquela que fará em sua arte, ao imaginar a possibilidade de uma amálgama entre as revistas e jornais ali vendidas durante o período de fechamento da loja:

A su lado hay un quiosco. Los señores se detienen a comprar el periódico;
las señoras, revistas. Por las noches, cuando el vendedor se va a casa,
¿qué ocurre con los periódicos y las revistas? Se quedan a hablar, hacen
travesuras, intercambian ideas. A la mañana siguiente es común encontrar
la foto central de una revista en la primera página del periódico. (PAZ-
SOLDÁN, 2011, p. 30). O quiosco apresentado acima, juntamente com a frase "Hoy va a llover" (PAZSOLDÁN, 2011, p. 36), tem valor indispensável para refletir sobre sua obra artística. Escrita na parede no momento de seu colapso, antes de seu aprisionamento, e retomada como último pensamento antes da morte do personagem, demonstra o estreito vínculo entre reprodução e memória para Martín. A frase, que segue a estrutura periodística, relaciona-se com a propaganda nas revistas e jornais utilizados em seus collages, que se misturam, na cabeça do personagem, com elementos de sua memória doméstica no México. Assim, as criações reproduzem um pensamento no qual, por um processo de metonimização, Martín projetaria a ideia do "sonho americano" vendido nas revistas ${ }^{12}$, que o leva ao exílio em busca de uma melhor fonte de renda, ao mesmo tempo em que traz o substrato afetivo de um terruño ao qual jánão pertence. Passado e presente, memória e realidade confundem-se formando

\footnotetext{
${ }^{12}$ Aqui vemos as revistas como uma versão editada da realidade, nas quais se usam artifícios que têm como objetivo "embelezar" seu conteúdo. Em Norte, um exemplo de relação difusa entre a situação lastimável de Martín e a vida "perfeita" vendida nas revistas está na página 73: "Pero nada de esole llamaba tanto la atención como la publicidad. Una mujer con una cofia en el pelo estiraba los brazos y le ofrecía un jabón. Los brazos parecían a punto de salirse de la página [...] Por las noches soñaba con la mujer del jabón, que se escapaba de las páginas de la revista y venía a echarse en la cama junto a él, y se acaban los dolores y los ruidos y el olor de amoníaco mezclado a mierda." (PAZ- SOLDÁN, 2011, p. 73).
} 
um só imaginário em sua arte. 
Martín a todo o momento interpreta o mundo por meio de sua materialidade, isto é, a tangibilidade sensorial pauta sua forma de existir enquanto sujeito. Dessa forma, o visual e o tátil são combinados em sua arte, sendo seus temas reflexos de um mundo de imagens interiores relativas à sua memória combinado a um exterior empírico, concreto. O onírico, porém, aparece, em meio aos trens e jinetes "reais", através das linhas paralelas que dão ideia de amplitude e escape, fazendo com que o desenho seja sua ferramenta de escape para outra espacialidade. Um dos seus desenhos é retratado da seguinte forma: "El vagón principal de una locomotora, con el humo que salía en círculos y lograba escaparse de la página”. (PAZ-SOLDÁN, 2011, p. 36).

Desse modo, a frequência de alguns temas na obra de Ramírez é retratada de modo equivalente na arte produzida pelo personagem. Sobre essa recorrência de tópicos Irwin (2014) afirma:

En el arte de Ramírez se repiten ciertas imágenes obsesivas. El jinete, el que aparece en más de cien obras suyas (Anderson, 'Drawing Landscapes' 22) es quizás la 'figura fundamental' de su producción artística (Espinosa y Espinosa 32). Se ha interpretado como un revolucionario (estilo Emiliano Zapata) o un vaquero (del cine de Hollywood) y puede que tenga algo de estas figuras, pero recientemente se ha sugerido que es un autorretrato de Ramírez delas primeras décadas de su vida, cuando, según recordaba una vecina, éste era 'un hombre de caballo' de mucha habilidad: pocos tenían la maña que demostraba Martín con su 'colorado retinto' (Espinosa y Espinosa 20). Los jinetes de Ramírez, casi siempre armados -aunque en sus últimos años de vida aparecen con menos frecuencia y muchas veces traen un clarín en vez de carabina se ubican en un proscenio construido de sistemas complejos de líneas paralelas. (IRWIN, 2014, p. 246).

As frequentes linhas paralelas, as quais dão a sensação de escapar da página e, consequentemente, do espaço em que se está inserido, também trazem amplitude e simbolizam deslocamento. Isso pode ser visto por exemplo, nas obras expressas abaixo: 


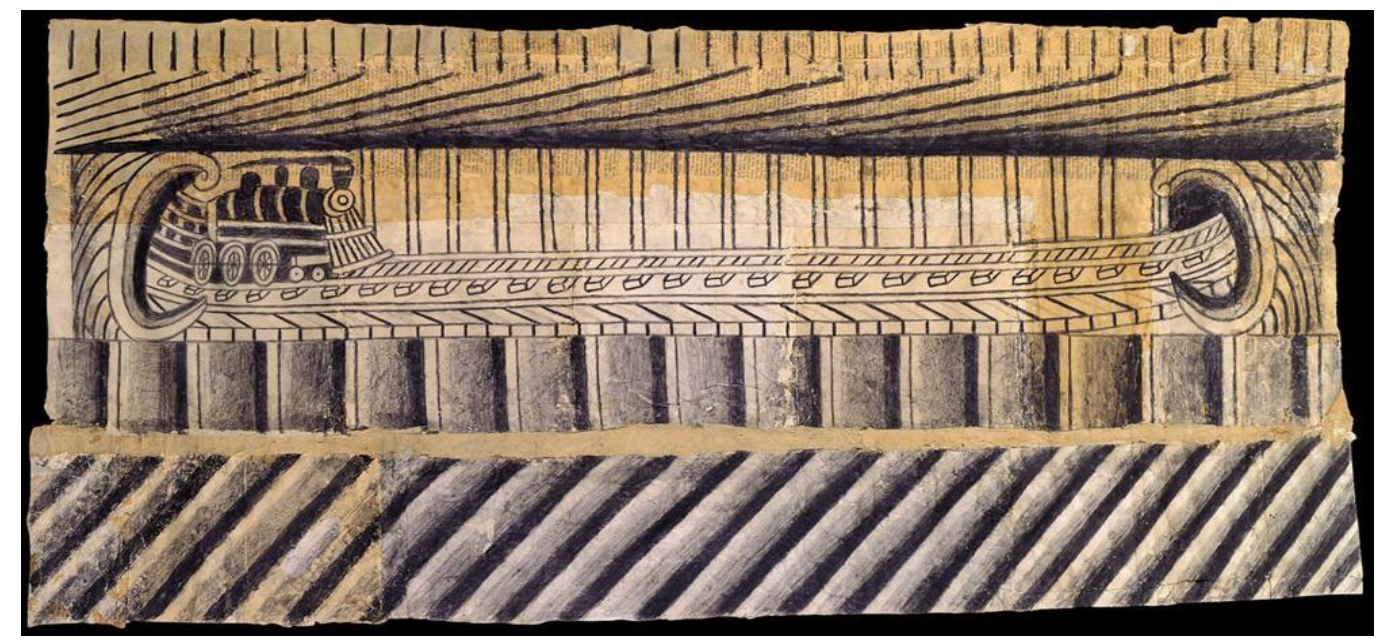

Fonte: American Folk Art Museum. Desenho de Martín Ramírez Sem título (Trem), c. 1953, lápis e giz de cera sobre papel, 55 x $120 \mathrm{~cm}$.

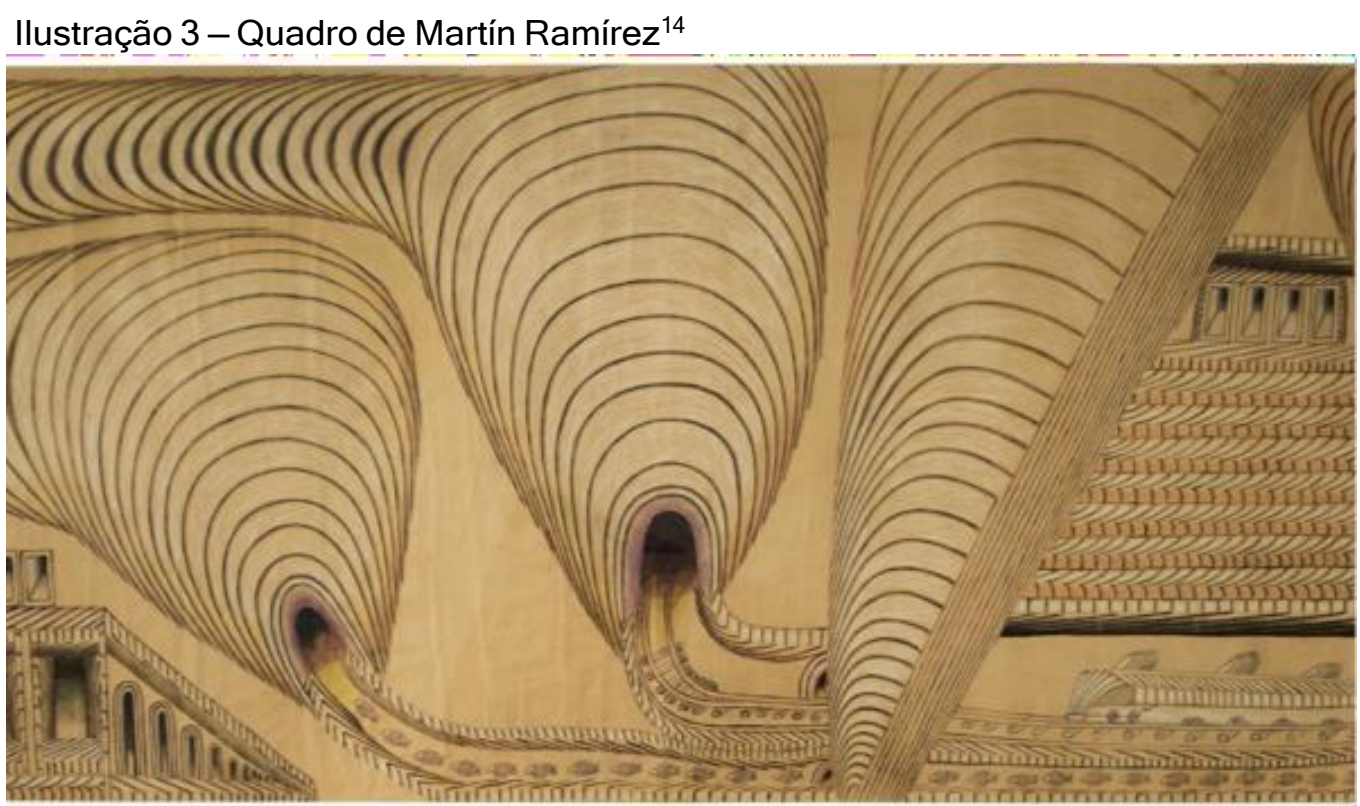

Fonte: Galeria virtual Ricco Maresca. Desenho de Martín Ramírez Sem título (Trem e Túneis), c. 1952-3, grafite, têmpera e giz de cera sobre papel, $91.4 \times 252.1 \mathrm{~cm}$.

Os quadros acima, todavia, não aparecem no formato de imagem na obra Norte, uma vez que Paz Soldán opta por representá-los na narrativa através de descrições verbais das obras de Martín. Tais quais as retratadas acima, elas estão

\footnotetext{
${ }^{13}$ Fonte:<https://folkartmuseum.org/exhibitions/martin-ramirez/>. No site em que a imagem foi extraída está presente a seguinte nota ao pé da fotografia: "UNTITLED (Train) Martín Ramírez (1895-1963) Auburn, California c. 1953 Pencil and crayon on pieced paper 22 1/2 x 47 in. American Folk Art Museum, gift of Herbert Waide Hemphill Jr., 1990.1.2 Photo by Gavin Ashworth".

14 Fonte: <https://www.riccomaresca.com/>. No site em que a imagem foi extraída está presente a seguinte nota ao pé da fotografia: "Martín Ramírez, Untitled (Train and Tunnels) NU243.321, c.1952-53, graphite, tempera and crayon on paper, 36 x 99.25 in; 91.4 x $252.1 \mathrm{~cm}$."
} 
presentes, por exemplo, no quarto capítulo da linha narrativa que narra a história do personagem: "Los temas no han cambiado. Jinetes con cananas cruzándoles el pecho, montañas de líneas onduladas, trenes y túneles, paisajes con iglesias y animales y gente bailando". (PAZ-SOLDÁN, 2009, p. 223).

Assim, ao longo de sua narrativa, Martín passa pelo processo de construção de sua não intencional posição de artista, sendo que suas mãos (figura elementar para a produção de arte) ocupam já desde as primeiras linhas lugar central nesse processo: "Martín cuenta los dedos de las manos. Uno, dos, tres, cuatro, cinco, seis, siete, ocho, nueve, diez. Los impares. Uno, tres, cinco, siete. Nueve. A comenzar de nuevo." (PAZSOLDÁN, 2011, p. 30).

Percebe-se, então, que por meio da metonimização suas mãos passam a se tornar epítomes de seu ser: são suas ferramentas de trabalho, visto a impossibilidade de um labor letrado e elaborado por conta de suas origens campesinas e da barreira que possui em relação à expressão via oral, maximizada por sua imigração aum espaço acerca de cuja língua possui pouco conhecimento lexical; são também seu modo de se acalmar diante das dificuldades (como na situação inicial, em que conta os dedos pares e ímpares como forma de distrair-se da hostilidade que é estar em outro país e não possuir um lugar para morar) e, até mesmo, essas mãos cumprem a função de ser seu meio de comunicação quase que exclusivo, já que o personagem acolhe o desenho com via de interação em detrimento da linguagem oral.

É com base nisso que retomamos Foucault para apontar a estrutura opressiva de poder que atinge o sujeito dado como louco e é reforçada pela situação asilar, no que se refere ao âmbito de produção semiótica, já que a voz desse indivíduo é frequentemente esvaziada de sentido por aqueles considerados sãos. Tal fato tem como origem o processo desencadeado desde a nosologização da insânia e que culmina, no século $X X$, com o advento da psicanálise e, com ela, os métodos de análise do inconsciente. A partir daí ocorre muitas vezes "uma disjunção completa entre os sujeitos doentes e seus discursos. Por que, então, fazer circular a obra e não os sujeitos?" (FRANCO, 2011, p. 55). Franco ao tratar de tais temas em sua pesquisa, promove uma leitura da obra já mencionada de Foucault (1997) da seguinte forma:

Ao ganhar um crivo médico que cerceava a loucura na doença mental (e a resumia nisso) os insensatos, os imbecis e os dementes foram silenciados; e sua linguagem foi esvaziada de seu caráter produtivo e transgressivo. A linguagem do doente 
mental tornou-se um amontoado "desarrazoado", cheia de interditos, condenada ao confinamento em prol de uma defesa social que a transformava em um perigo iminente. $O$ sujeito louco e doente, mas também seu discurso, estava fadado a uma "ausência da obra" que o definia. (FRANCO, 2011, p. 54).

Goffman, por sua vez, afirma que nas instituições totais frequentemente "violenta-se a autonomia do ato." (GOFFMAN, 1961, p. 42), isto é, tira-se a capacidade de ação ao subjugar o sujeito ao coletivo padronizando seus modos de agir por meio de atos rotineiros cronometrados e constantemente vigiados, sendo que quem subverte tal organização coloca-se imediatamente passível de punição física e/ou moral por parte da equipe dirigente. Mesmo que possivelmente de forma inconsciente, isso faz com que Martín busque de certo modo retomar, por meio de sua arte, o controle de seu próprio tempo, uma vez que cada um de seus projetos poderia ser apenas exclusivamente executado em seu próprio ritmo, tudo o que podem fazer (e fazem) é assinalar a data de cada uma das produções e guardá-las. Assim, a íntima relação entre artista e obra faz, além disso, com que ele crie para si outras territorialidades para além do ambiente restrito em que está subscrito, as quais são concebíveis apenas no contexto de cada um de seus desenhos, pinturas e collages. É como se por meio de sua arte o tempo e o espaço pudessem ser momentaneamente desprendidos, o que reforça a ideia de que o personagem resiste à territorialidade coercitiva da instituição total em que está inserido ao trazer como alternativa outra territorialidade que conforma através de sua arte.

Além disso, fica evidente que os funcionários do hospital veem a produção artística de Martín como um trabalho, já que o dispensam do mesmo a partir do momento em que o professor o destaca como um prodígio, para que pudesse dedicarse mais tempo e, com isso, produzir cada vez mais obras. A respeito do trabalho por parte dos internados, Goffman (1961, p. 41-42) explica que ele é fundamental nesse tipo de instituição não apenas por conta da importância que a produtividade assume na sociedade civil, mas porque ali ele se torna mais uma ferramenta para o controle de indivíduos. Dentro do contexto hermético, porém, o trabalho acaba por ser, para aqueles que o fazem de forma compulsória, apenas mais uma ação despojada de qualquer motivação que não o medo de uma possível punição.

O personagem, por outro lado, ao lidar como o seu fazer artístico, trata-o como forma de expressão e escape do espaço físico limitante em que está inserido (mesmo que isso se dê muito possivelmente de maneira inconsciente), não buscando conscientemente ser artista, traço que o difere da personagem Michelle, que faz arte 
movida por um conhecimento do cânone literário ao qual busca subverter, provendo um modo próprio de ser escritora.

Como parte de sua técnica artística, Martín opta também pelo o uso de materiais inusuais, inclusive fluidos corporais e produtos alimentícios, os quais provavelmente seriam vistos como abjetos em situações exteriores ao hospital psiquiátrico, mas que no contexto destes espaços são elementos normalizados, especialmente por conta da proibição de bens pessoais, o que pode fazer com que eles se tornem uma espécie de pertence de seu detentor. Além disso, as frequentes situações degradantes pelas quais as pessoas detidas nesses espaços costumam passar podem ser vistas como mais um motivo para que os elementos escolhidos pelo personagem sejam, efetivamente, particulares à sua situação de detento de uma instituição total.

Retomando o caso do mutismo seletivo de Martín, este, todavia, é um tanto quanto específico e parece ser pautado por uma série de fatores, sendo o silenciamento e o distanciamento discursivo que compelem os que estão à margem da sociedade à subalternidade semiótica apenas uma de suas facetas. Conquanto, Martín segue reforçando o desenho como forma de expressão comunicativa: "A veces escribía cartas a María Santa Ana y a sus hijos, pero escribir no era el término exato: en vez de palabras contaba de sus días en imágenes coloridas, un hombre de sombrero que entraba y salía de edificios bajo un sol muy amarillo." (PAZ-SOLDÁN, 2011, p. 71).

Desse modo, as lembranças maternais que o personagem evoca deixam pistas de um constante envergonhar-se frente à sociedade. Em seu pensamento, Martín volta à infância, época em que jogava pedras nos sapos que coaxavam nas noites de chuva pela razão de incomodarem seu sono, sendo penalizado por sua mãe quando esta o segue e descobre a ação: "Hasta que su madre lo siguió y le dijo eso no se hace, desgraciado, y él disculpas, la cara al suelo, las orejas que le ardían como cada vez que se avergonzaba de algo. Y se avergonzaba de muchas cosas. Su vida era avergonzarse de lo que le ocurría." (PAZ-SOLDÁN, 2011, p. 30).

As marcas psicológicas acabariam sendo assinaladas, naquele momento, em sua corporalidade por meio das orelhas ardendo, o que se intensifica paulatinamente levando ao ponto da interdição quase que completa de sua fala. 
Para ele, "todos deberían ser como él. No hablar, simplemente dibujar." (PAZSOLDÁN, 2011, p. 35).

\subsection{0 migrante como sujeito fronteiriço}

O narrador da linha narrativa centrada na história de Martín tem como características ser onisciente seletivo, fazer uso de um incipiente fluxo de consciência e empregar frequentemente o discurso indireto livre, ajudando a fazer com que os pensamentos e formas de existir do personagem enquanto "sujeito fronteiriço" sejam expostos aos olhos atentos do leitor. Com isso, as fronteiras tornam-se determinantes para suas conexões com o mundo a seu redor, no que se refere à contínua reconstrução do personagem e suas figurações, as quais são fruto, por sua vez, de uma acumulação de embates fronteiriços.

As fronteiras espacial e linguística delimitam o não pertencimento de Martín àquela pátria, sendo fruto do deslocamento físico do personagem para o país ao norte, no qual o preconceito racial e socioeconômico por ele sofrido mostra-se latente nas relações que estabelece, como pode ser visto nos laços forjados entre patrãoe empregado; paciente e enfermeiro/médico. Um exemplo dessa discriminação sofrida são as palavras "Filti mexican", ouvidas por ele após sua internação e pronunciadas por um dos enfermeiros que deveria cuidá-lo. Nesse e em outros momentos, as especificidades da linguagem falada são construídas na textualidade escrita por meio de um procedimento em que se busca a reprodução fonológica das palavras, reproduzindo sua oralidade e, portanto, não seguindo os preceitos da norma padrão. Isso se dá especialmente com palavras que estão em língua inglesa, as quais são "espanholizadas" pelo personagem, enfatizando seu escasso conhecimento do idioma estrangeiro e marcando ainda mais seu distanciamento em relação àqueles que seriam, dentro do âmbito institucional, articuladores das estruturas de poder.

No caso da fronteira entre sanidade e loucura, configura-se o deslocamento social imposto por conta da possível enfermidade mental e, consequentemente, físico (visto que o obriga a isolar-se em um hospital psiquiátrico, com o qual ele passa a estabelecer uma relação de resignação: suas fugas passam por um processo em que, aos poucos, culminam em uma volta voluntária, até chegarem ao ponto de deixarem de existir). Dessa maneira, o personagem passa a sentir como se aquele fosse o único 
lugar ao qual pudesse pertencer, sendo que apesar de sentir falta de sua terra natal, sabe que ela já não Ihe pertence, tratando-se somente de uma idealização saudosista.

Finalmente, temos a fronteira entre o artístico e o não-artístico, na qual o personagem e sua arte posicionam-se em dubiedade, assim como ocorre com outros artistas julgados insanos, os quais buscam, assim como o faz Martín, expressar-se mais por meio de elaborações manuais do que através da oralidade. Assim, por conta da capacidade de razão tida como restrita, a arte dessas pessoas é frequentemente relegada, como vimos, a subcategorias, muitas vezes vistas com desprestígio e preconceito daqueles que julgam tratar-se de expressões artísticas com valor estritamente estético.

Desse modo, Martín cruza a fronteira espacial entre os países, é diagnosticado como esquizofrênico e internado e a partir daí, por meio da intervenção de Tarmo Pasto, transmuta em arte seus desenhos e collages, próprios tanto de sua comunicação, quanto de seu intendo de fuga da espacialidade opressora em que o inserem. Todo esse processo culmina no reconhecimento pelos demais enquanto artista, ainda que estes últimos elementos tenham acontecido de forma desintencional, uma vez que se trata sobre tudo de uma interferência externa aos motivos e desejos do personagem.

É em meio à margem social que sua subjetividade outsider é (trans)formada, criando novas territorialidades e modos de existir. Finalizamos, com isso, afirmando que não se trata de uma situação de desterritorialização, já que segundo Haesbaert (2004), não existe a possibilidade de que uma pessoa não esteja de algum modo territorializada, mas de um processo de reterritorialização, conforme concebe o autor, em meio às singularidades vivenciadas pelo personagem ao longo de sua trajetória, especialmente enquanto sujeito imigrante, trabalhador subsalariado, paciente em instituição psiquiátrica e artista autodidata, as quais interseccionam-se para a construção da subjetividade do personagem. Enfatizando a importância das relaçõesde poder que são estabelecidas em cada um dos espaços e em que ingressa, sejam eles de âmbito estatal (como seu ingresso nos Estados Unidos) ou em instituições fechadas, isto é, no caso dos hospitais psiquiátricos. Além de sua breve passagem por galerias de arte em que suas obras foram expostas, tal como é demonstrado no primeiro capítulo da quarta parte de Norte, ainda que isso sempre tenha ocorrido juntamente com alguém cuja função é não apenas acompanhá-lo, mas, 
sobretudo controlá-lo, mostrando que mesmo nos momentos em que o personagem é visto por outras pessoas como artista sua condição de internado fala mais alto.

Assim, a figuração como trabalhador imigrante é retratada, principalmente, no começo da linha narrativa que aborda a história de Martín. Nela, o personagem resgata através da memória sua dificuldade com o idioma estrangeiro, as características físicas e psicológicas do grupo de trabalhadores com os quais convivia e como a relação entre os empregados e o patrão era estabelecida nesse ambiente. Um exemplo disso está em:

Debió haber aprendido inglés. Sobre todo para venirse aquí. La pasó mal
durante la construcción de vías, aunque después mejoró el trabajo durante
una temporada. Para recolectar fresas o naranjas no era necesario hablar.
En las minas también estaba yendo bien. Ahí se amontonaba con otros
hombres como él, de su edad o mayores y hasta chamacos, y de todos los
pueblos. Algunos llevaban sombreros y otros no. Algunos llevaban cintos con
hebillas enormes con figuras de pistolas y otros no. Algunos llevaban botas y
otros huaraches de llanta. (PAZ-SOLDÁN, 2011, p. 32).

A figuração como prisioneiro de guerra é restrita exclusivamente à ótica de Martín sobre sua própria condição no momento em que é enclausurado no hospital psiquiátrico, dado que ele acredita que o haviam denunciado como um combatente cristão, ainda que em solo estrangeiro. Tal representação pode ser vista no trecho abaixo:

María Santa Ana estaría orgullosa de él. Era un prisionero que no se rendía.
Un prisionero capaz de hacer que se arrodillaran sus enemigos. Creían
tenerlo arrestado, pero en el fondo era él el que los tenía arrestados a ellos.
La guerra continuaba en otro lugar, pero allí bien al norte él se las arreglaba
para que no todos pudieran pelear contra su país. Para que se quedaran,
distraídos, cuidándolo. Para que María Santa Ana ganara tiempo. (PAZ-
SOLDÁN, 2011, p. 70-71).

A figuração do personagem como insano é, por sua vez, conformada a partir das circunstâncias em que ele está inserido, as quais fazem com que Martín passe por um processo involuntário de construção identitária dentro do "mundo do internado"15. Nele, a percepção errônea de sua própria realidade e a crença na posse de um superpoder são elementos fundamentais para que sua possível condição psíquica seja ratificada tanto pelos membros da equipe dirigente do hospital psiquiátrico quanto por aqueles de sua mesma condição. Relembramos ainda que a segunda característica trata-se de uma recorrência em pessoas internadas em asilos e hospitais psiquiátricos,

\footnotetext{
${ }^{15}$ Seguindo a terminologia utilizada por Goffman no livro Manicômios, prisões e conventos, a qual visa especificar aquilo que seria próprio do ponto de vista das pessoas ingressas em instituições restritivas. O termo estaria em oposição ao "mundo da equipe dirigente".
} 
de modo que isso é representado no romance por seus companheiros também hospitalizados, os quais acreditavam, por exemplo, serem heróis ou deterem um spray que faria as pessoas invisíveis: "Mai esprai uil meik yu invisibol." (PAZ-SOLDÁN, 2011, p. 141). Além disso, é importante que frisemos o comportamento excêntrico que o personagem desempenha em uma de suas tentativas inusitadas de reingresso na sociedade, realizada após uma fuga da instituição em que estava enclausurado:

Una tarde, estando solo mientras regaba las plantas, se largó acorrer y se escapó del edificio. Llegó a la ciudad y no supo que hacer. Se detuvo en una esquina y miró fijo a la gente que pasaba. Una señora se asustó y preguntó qué le ocurría. Martín pronunció incoherencias. Dos jóvenes quisieron ayudarlo y él les sacó la lengua y se puso a toser y luego se bajó el pantalón y se masturbó delante de ellos. Alguien llamó a lapolicía.

Al rato, volvía a estar en su cama, en su sala, en el edificio. ¿Su edificio? (PAZ-SOLDÁN, 2011, p. 75).

Esse tipo de conduta bizarra é, todavia, absolutamente previsível em pessoas nesta situação quando têm contato novamente com o espaço externo ao hermetismo ao qual já estavam habituadas por conta de tantos anos inseridas em uma instituição total, conforme explica Goffman: "Por isso, se a estada do internado é muito longa, pode ocorrer, caso ele volte para o mundo exterior, o que já foi denominado "desculturamento" - isto é, "destreinamento" - que o torna temporariamente incapaz de enfrentar alguns aspectos de sua vida diária”. (GOFFMAN, 1961, p. 23).

Por fim, chegamos à figuração do personagem como artista autodidata. Nela, nos referimos ao processo único de seu fazer artístico e ao reconhecimento próprio e alheio de Martín como criador de arte, especialmente após o contato com o personagem que representa o professor Tarmo Pasto. Martín busca a arte como tentativa de constituir uma territorialização para além do espaço asilar. Desse modo, é possível vê-lo em sua posição de artista no seguinte fragmento, em que se enfatiza seu desconhecimento de nomes importantes da História da Arte. Isso permite que suas criações sejam autênticas, além de marcar que elas eram construídas no seu próprioritmo, respeitando sua própria maneira, para além dos horários rígidos da instituição:

El profesor le decía que tenía fe en su talento. Que lo admiraba. Que creía que había encontrado a un Jenri Rusó mexicano. ¿Qué? Jenri. Russsoooó. Eso. Ajá. Y le traía cuadernos, revistas y colores. Estaba bien así. Podía dejarlo hablar siempre y cuando trajera todo lo que necesitaba para dibujar. Y Martín dibujaba. Había desarrollado una rutina minuciosa, que comenzaba con él sacando las hojas de los cuadernos y colocándolas en el suelo una junto a otra, para pegarlas y tener un espacio más amplio para dibujar. Después preparaba la pasta inventada por él, en la que mezclaba, entre otras cosas betún, crayones, carbón, el jugo rojo que extraía dealgunas frutas, y su saliva, de preferencia con mucha flema. (PAZ-SOLDÁN,2011, p. 
174).

Chegamos, desse modo, como conclusão, à ideia de que a condição fronteiriça que Paz Soldán sublinha como traço fundamental de seu personagem abre espaço para quatro representações fundamentais de Martín: trabalhador imigrante, prisioneiro de guerra, interno em instituição de cunho psiquiátrico e artista autodidata.

Tais representações unem-se e materializam-se para a percepção que se cria de Martín, provendo a base para construção de sua subjetividade ao longo da narrativa. Tratamos, assim, de promover a aplicação do conceito de figuração baseando-nos nas ações, pensamentos, linguagens e relações interpessoais vivenciados pelo personagem estudado, bem como refletindo acerca dos lugares sociais por ele ocupados. Lembrando também de que a forma como ele e sua arte se relacionam com tais espaços (Estados Unidos, México e a instituição total na qual ele está enclausurado) e temporalidades (presente e passado, sendo este evocado através da memória), muitas vezes ocasiona novos movimentos e, consequentemente, novas formas de se territorializar, visto que a arte se torna uma ferramenta para que ele possa se deslocar das opressões sofridas, des(re)territorializando-se. 


\section{Capítulo 2. Jesús: o território da marginalidade}

Não é nenhuma novidade que assassinos e assassinatos mexem com o imaginário popular, sendo ainda maior a repercussão quando estes dizem respeito a casos envolvendo violência extrema, como torturas, estupros e mutilações, assim como assassinatos cometidos em sequência por um mesmo indivíduo sem que haja um motivo aparente, bem como, muitas vezes, algum elo que possa ligar as vítimas entre si, além da má sorte de terem estado em um determinado local na hora errada (o qual pode ser até mesmo a sua própria casa), sendo, por conta disso, mortas pela mesma pessoa. O serial killer Jesús, cuja história analisaremos neste capítulo, constrói sua personalidade adotando referentes como o lutador mexicano Aarón Rodríguez Arellano, mais conhecido por seu personagem Mil Máscaras, e o ator honconguês Jackie Chan, ambos popularizados por papéis nos quais atuam de forma heroicamente violenta.

Dessa forma, para o personagem, a violência que observa nos momentos em que assiste à televisão mistura-se com aquela que está perpetuada em seu cotidiano enquanto habitante do espaço conturbado da fronteira que se dá no limite geopolítico divisório entre as nações do México e dos Estados Unidos, sendo intensificada por ele ser pertencente a uma família de baixa condição econômica, além de ter deixado de frequentar a escola ainda muito jovem. Tais cruzamentos entre violênciareal e fictícia fazem com que Jesús interprete a sua realidade concreta através das ferramentas proporcionadas pela ficção televisiva, implementando nela esses elementos: "Había querido ser como Mil Máscaras para cruzar al otro lado. Tener trucos capaces de derrotar la hostilidad de esos sujetos malencarados que custodiaban el ingreso a su país". (PAZ-SOLDÁN, 2011, p. 46).

Quando Serelle (2012, p. 262) fala de uma cultura da fetichização testemunhal, ele se refere a produtos culturais como o programa Linha Direta ${ }^{16}$, veiculado entre os anos 1997 e 2007 pela rede Globo, principal emissora de televisão do Brasil. Neste, ocorria semanalmente uma dramatização, tal qual as que ocorrem nas novelas

\footnotetext{
${ }^{16}$ O equivalente estadunidense ao programa "Linha Direta" seria Dateline, da rede televisiva NBC, o qual segue sendo transmitido atualmente. Em um formato semelhante, a CBS News veiculou, no ano de 2018, um programa sobre Ángel Marturino Reséndiz, intitulado segundo o cognome Railroad Killer, que lhe foi dado pela mídia por conta de seus crimes terem sido cometidos principalmente nas proximidades das linhas de trem.
} 
televisivas, entremeada por comentários do apresentador, expondo casos que envolviam uma gama extensa de crimes, os quais eram quase sempre hediondos, e então o criminoso era figurado como uma verdadeira anomalia social, tal qual ocorre com os instrumentos midiáticos representados em Norte, os quais afirmam veementemente que "[...] la ley quebrantada habría de restaurarse" (PAZ-SOLDÁN, 2011, p. 201).

O sucesso desse tipo de atração, comum em diversos países ocidentais, fundamenta-se na possibilidade de "espiar" o momento do crime, ou seja, desde o conforto de nossos lares testemunharmos "por completo" um caso que seria confidencial, assunto particular ao restrito âmbito investigativo, daí a importância de que haja uma dramatização com direito a um elaborado enredo, da mesma forma que ocorre com as reconstituições do momento do crime feitas pela polícia durante a apuração criminal. Isso faz com que seja atraído um grupo extenso de pessoas a fim de descobrirem o que realmente teria acontecido naquele momento desditoso, bem como quais seriam as possíveis motivações do criminoso. É a esse outro lado que a obra dá-nos acesso. A perspectiva do assassino Jesús vem entremeada pela do ranger Rafael Fernandez, responsável por sua captura definitiva, permitindo ao leitor uma visualização multifacetada dos acontecimentos narrativos, os quais acabam por convergir através do trabalho de intermediação realizado pelo foco narrativo em terceira pessoa, que utiliza de seu caráter omnisciente para nos revelar o que se passa no íntimo de cada um dos personagens, aprofundando-nos em cada um de seus conflitos interiores.

Partindo da ideia de que Jesús toma como inspiração de vida aspectos provenientes de interpretações sobre personagens da ficção, ele procura buscar um elemento que o distinga e lhe confira certa autoridade, da mesma maneira que Mil Máscaras constrói sua forma de expressão e singularização justamente através de suas máscaras. $O$ personagem faz isto com o objetivo de buscar uma reterritorialidade, uma vez que se torna um sujeito que havia ingressado "en ese país que durante tanto tiempo imaginó como imposible" (PAZ-SOLDÁN, 2011, p.55).

Ainda assim, apesar da fascinação por ele demonstrada ao chegar aos Estados Unidos, ou mais especificamente, em Landslide (cidade fictícia, sobre a qual discorreremos no terceiro capítulo desta dissertação, já que tal local serve como 
ambiente para que se desenvolva a linha narrativa em que Michelle é personagem principal), há certa recorrência familiar no ato de atravessar a fronteira geopolítica que separa os países, afinal seu pai a havia cruzado e não mais voltaria e Jesús lembrara no momento da ação de transpasse que "de niño su madre le había contado que hizo ese viaje muchas veces, cuando necesitaba lana y debía emplearse de sirvienta o mesera en El Paso". (PAZ-SOLDÁN, 2011, p.54).

Desse modo, com o objetivo de reterritorializar-se, o jovem compra um blazer cinza, que "le quedaba grande" (tal qual os atos criminosos que apesar de sua pouca idade, já estava cometendo), "pero el color le gustaba” (PAZ-SOLDÁN, 2011, p. 56). Além disso, o personagem não abandona a ideia de usar máscaras, assim como seu herói, utilizando-as diversas vezes, sempre com o objetivo de adotar uma postura amedrontadora em relação a alguém que deseja intimidar. Com isso, as máscaras sociais metafóricas, isto é, suas várias figurações ao longo da narrativa (assassino, estuprador, prisioneiro, imigrante, esposo, filho e professor) materializam-se a partir do momento em que são vestidas máscaras reais, concretas. Porém, tais máscaras rompem-se. É preciso encontrar a si mesmo para além de toda a farsa. Em um acesso de fúria ao descobrir que seu ídolo era, em realidade, obra ficcional, Jesús decide atear fogo em todas as máscaras que tinha guardadas em seu armário e, após isso, passa a sentir-se melhor. A partir desse momento já não as vestiria mais.

Posto isso, a violência, seja aquela que se dá interna ou externamente ao romance, trata-se sempre de uma questão social, ainda que no caso da narrativa em questão ela seja posta em relevância por conta de um aspecto comportamental específico do personagem. Daí que ela não se origina por si só, mas também a partir da influência que possuem os meios de comunicação de massa, como trabalhamos acima, e as ferramentas culturais, os quais produzem e reproduzem seus valores (aqui se referindo à construção de estereótipos e cristalizações da figura do delinquente, dado que promovem uma leitura reiteradamente simplificadora). Assim, tais estruturas servem como base para a construção das sociedades ocidentais modernas, bem como dos espaços de convívio dos sujeitos que as compõem.

Partindo da ideia de que as consequências da violência podem resultar em um problema de saúde pública, a OMS (Organização Mundial da Saúde) publicou noano de 1996 o WHO Global consultation on violence and health, documento em que 
define o conceito de violência como "o uso intencional de força física ou poder, real ou como ameaça contra si próprio, outra pessoa, um grupo ou uma comunidade,que resulte ou tem grande probabilidade de resultar em ferimentos, morte, danos psicológicos, desenvolvimento prejudicado ou privação." (Organização Mundial da Saúde, 2014, p. 2). Tal definição colabora para que possamos entender melhor a problemática da violência $e$, evidentemente, possamos ter uma base mais aprofundada das formas de atuação de seus agentes, assim como de suas vítimas.

Dados os esclarecimentos iniciais, Jesús María José González Reyes é o correlato ficcional de Ángel Maturino Reséndiz, cujo pseudônimo mais utilizado é RafaelResendez-Ramirez, o que acarreta em um possível jogo irônico de Paz Soldán como nome do personagem policial que o antagoniza. Além disso, é importante ressaltarmos também o epíteto The Railroad Killer, o qual segue um processo de antonomásia ao referir-se aos assassinatos por ele cometidos no decorrer das vias de trem e popularizado principalmente através dos meios de difusão de informação estadunidenses, como rádios e canais televisivos.

A escolha de Paz Soldán por nomes distintos de entre personagens e pessoas que os inspiraram permite-nos transitar com mais liberdade entre o que faz parte da ficção e o que se trata de realidade, uma vez que não serão necessárias estratégias de diferenciação como aquelas que foram adotadas no primeiro capítulo desta dissertação. Ademais, o policial supracitado Rafael Fernandez, trata-se de uma livre inspiração do autor baseada em Andrew Carter ${ }^{17}$, ou Drew Carter, o qual atuava na patrulha de fronteira na época em que, por meio de negociações com a irmã de Ángel, Manuela Maturino (em Norte representada pela personagem Maria Luisa), consegue realizar a prisão do foragido. O grande diferencial em relação ao estadunidense Andrew Carter, é que Paz Soldán opta por construir o personagem de Rafael Fernandez de modo que ele seja, assim como Jesús, mexicano. Isso faz com que a problemática da relação entre fronteira, imigração e imigrante adense-se, já que em seu ponto de vista concentra-se a ótica do lado institucional da situação, isto é, a polícia enquanto órgão do Estado agindo efetivamente como instrumento de

\footnotetext{
17 Para que tais informações fossem coletadas, foram consultadas publicações de jornais datadas de julho de 1999 sobre a prisão de Ángel Marturino Reséndiz, ocorrida após as negociações promovidas por Andrew Carter. Tais notícias encontram-se atualmente digitalizadas, sendo estes alguns dos sites pesquisados: <https://www.cbsnews.com/news/drew-carter-texas-ranger/>. Acesso em 01 de junho de 2020 e <http://edition.cnn.com/US/9907/14/ranger.sidebar/index.html>. Acesso em 01 de junho de 2020.
} 
controle, mas também a perspectiva única de ter sido ele mesmo mais um integrante do largo processo de deslocamento humano para o país ao norte.

\subsection{Gênero negro e violência corporal}

Dito isso, os capítulos destinados a contar a história de Jesús e, consequentemente, de Rafael Fernandez, desenvolvem-se de forma similar às estruturas utilizadas para a construção de narrativas policiais e de romances negros, ainda que se aproximem mais com estes do que com aquelas, já que as narrativas policiais costumam ter, conforme explica Jafet Israel Lara (2012), o foco principal da trama na resolução de um crime, centralizando o ponto de vista narrativo em seu investigador, sendo no caso aqui estudado, o ranger Rafael Fernandez. Já no que diz respeitoaos romances negros, o autor afirma:

La novela negra significa una ruptura en una vasta frontera que incluyó lo policíaco, lo criminal, el thriller, lo psicológico y el espionaje, convirtiéndose en un híbrido literário que incorporó elementos genérico-textuales de varias narrativas y que, finalmente, es difícil de clasificar. (ISRAEL LARA ano da citação original, apud RAMOS ORTEGA, 2012, p. 36).

O romance negro surge, então, a partir do encontro entre gêneros, adotando para tal fusão procedimentos narrativos próprios da prosa contemporânea. Desse modo, ele utiliza-se de temáticas sociais obscuras, como a violência que se desenha no cotidiano dos habitantes das cidades modernas, para estabelecer uma narrativa pautada pela tensão. Ademais, seus enredos transcorrem especialmente nos anos finais do século XX e no começo do século XXI, o que marca seu caráter atual.

Já no que diz respeito à diferença mais evidente em relação às narrativas policiais é que nesse tipo de romance a violência ganha o espaço central da trama, fazendo com que todos os fatos girem em torno dela. Já não se transpassa ao leitor um sentimento de tranquilidade advindo da resolução do crime, sobretudo porque não esse é o objetivo do enredo, isto é, o foco não é reestabelecer a ordem social, a qual teria sido rompida no momento em que se cometeu o crime em questão, mas sim mostrar a conduta criminosa como um agravante gerado e multiplicado por uma sociedade corrompida. O que fica ao final do livro, nos romances negros, é apenas o 
desconforto e a insegurança gerados pela sensação de inexorabilidade da violência assim como ocorre em Norte.

Lo noir, como el llamado Alto Modernismo, afirma Horsely, representa la reacción a una crisis cultural y ofrece una representación de psiques fragmentadas, individuos alienados, y una frustración general con las promesas fracasadas del "sueño americano". (NICHOLS, 2010, p. 299).

Nesse ponto, enquanto no romance a mídia reproduz a mesma lógica em que se baseiam os romances de cunho policial ao afirmar que "[...] la ley quebrantada habría de restaurarse" (PAZ-SOLDÁN, 2011, p. 201), o narrador desta linha narrativa de Norte contrapõe-se. Isso se dá ao mostrar como Fernandez interpreta os delitos cometidos por Jesús, vendo-os dentro da estrutura narrativa própria do romance negro: a ideia de uma inevitabilidade social do mal que adviria organicamente da conduta violenta de seus componentes. Para tal forma de pensamento, isso seria algo que se originaria de modo quase que natural ao ser humano, devendo ser resolvido de forma pragmática, ou seja, através da aplicação da pena de morte ao infrator:

Era fácil entender que el mal atrajera, fascinara, sedujera. Era más complejo aceptar que el mal, el horror, el abismo, fueran parte fundamental de la vida. Destacable, que el FBI tuviera un encargado de meterse en la cabeza de los asesinos en serie: alguien tenía que hacerlo. Pero Fernandez había llegado a la conclusión de que era mejor no intentar entenderlos. Ellos eran, y punto. Había que arrestarlos y despacharlos con una inyección letal. (PAZSOLDÁN, 2011, p. 201).

Belén Ramos Ortega (2016) explica que a construção textual na história de Jesús, principalmente nos momentos em que seus crimes são descritos, gira em torno de uma estrutura narrativa na qual o terror utiliza-se dessa inevitável violência para transmitir-se de modo frio e direto, sem que haja pausas para elucubrações moralizantes e juízos de valor por parte do narrador em terceira pessoa. Dessa maneira, a forma e o conteúdo do texto combinam-se através de um narrador que corrobora para que o aspecto de frieza e falta de pathos apresentados pelo personagem central nos momentos em que comete estupros e assassinatos estejam presentes também em seu método narrativo. Em outras palavras, do mesmo modo que Jesús comete seus assassinatos de maneira insensível, o narrador demonstra o mesmo ao narrá-los evitando sensacionalismos, assim como qualquer tipo de observação que possa ajudar no distanciamento entre o leitor e as cenas violentas, as quais são construídas tal qual uma composição de imagens, uma vez que a mediação é mínima: 
Es un terror que se narra de manera fría, sin arroparse en el morbo, con enunciados cortos y significativos silencios; esquema formal que se ajusta muy bien a la escalada de asesinatos, actos vejatorios, humillaciones y venganzas que son la propia razón de ser de alguien - Jesús profundamente dolido con el mundo y que atenta contra tantas vidas inocentes. (ORTEGA, 2016, p. 151).

Esse tipo de construção narrativa apresentada por Ortega pode ser visto em diversos momentos impactantes da trajetória de Jesús, sendo um exemplo disso a seguinte cena de estupro cometida por Jesús, após ter assassinado mais uma de suas múltiplas vítimas:

La desvistió. Tenía los calzones orinados, puerca. Hizo una pila con su ropa y la tiró al tacho de basura. Volvió a sentarse sobre Joanna. Se masturbó frente a ella. La penetró. Se fijó en la masa sanguinolenta en el lugar en que antes había estado su rostro. Se movió rítmicamente, con furia, hasta que sintió un ramalazo eléctrico que venía de lo más profundo. Sacó su verga y se acercó al lugar del rostro y terminó sobre él [...]. (PAZ-SOLDÁN, 2011, p. 163).

Assim, como podemos ver, o narrador descreve cada uma das ações do personagem sem que haja forma alguma de pausa ou distanciamento. Tudo é construído diante dos olhos atentos do leitor de forma clara e precisa. Não há espaço para quaisquer divagações. Trata-se da exposição máxima do personagem, de modoque, mesmo o leitor tendo acesso às suas reflexões, a figura do assassino sanguinário que mata utilizando-se da violência extrema não é romantizada (como acontece diversamente com a figura do delinquente nos filmes massivos, de modo que, o que se projeta nestes não é fidedigno à realidade, uma vez que é envolto em uma aura de misticismo e idealização), mas sim desmistificada, o que é intensificado pelo fato de tratar-se de um estuprador. Para comprovar tal posição por parte do narrador, podemos ressaltar que antes da ação que acontece no trecho acima, a personagem Joanna havia sido morta por Jesús espancada por meio de socos e golpes com um taco de beisebol, além de ser esfaqueada com uma faca serrilhada.

Rita Segato, professora cuja especialidade são os estudos sobre violência, especialmente aquela que atenta contra o domínio do sujeito do gênero feminino, em sua pesquisa intitulada La escritura en el cuerpo de las mujeres asesinadas en Ciudad Juárez, discorre, como afirma o subtítulo, sobre "Territorio, soberanía y crímenes de segundo estado". Analisando o contexto da cidade de Juarez, estabelecida em uma espacialidade fronteiriça entre México e Estados Unidos, Segato afirma:

La víctima es expropiada del control sobre su espacio-cuerpo. Es por eso que podría decirse que la violación es el acto alegórico por excelencia dela definición schmittiana de la soberanía: control legislador sobre un territorio y sobre el cuerpo del otro como anexo a ese territorio. Control irrestricto, 
voluntad soberana arbitraria y discrecional cuya condición de posibilidad es el aniquilamiento de atribuciones equivalentes en los otros y, sobre todo, la erradicación de la potencia de éstos como índices de alteridad o subjetividad alternativa. En ese sentido, también este acto está vinculado a la consumición del otro, a un canibalismo mediante el cual el otro perece como voluntad autónoma y su oportunidad de existir solamente persiste si es apropiada e incluida en el cuerpo de quien lo ha devorado. Su resto de existencia persiste sólo como parte del proyecto del dominador. (SEGATO, 2013,p. 20).

Para a antropóloga, o ato de estuprar estaria relacionado à "consumición del otro, a un canibalismo mediante el cual el otro perece como voluntad autónoma y su oportunidad de existir solamente persiste si es apropiada e incluida en el cuerpo de quien lo ha devorado" (SEGATO, 2013, p. 20). Assim que, é importante frisarmos, haveria no estupro um ato de canibalismo simbólico, no qual o corpo passa a ser objeto passível de ser devorado.

Em uma de suas cartas escritas integralmente em inglês, Reséndiz aborda a temática do canibalismo, como é possível ver em sua fotografia abaixo, extraída da resenha Tren al norte, escrita pelo boliviano Bernardo Paz Gonzales, e publicada no site da revista cochabambina Ecdótica ${ }^{18}$ :

Carta manuscrita 1 - Carta de Angel Maturino Reséndiz.

Fonte: Revista Ecdótica

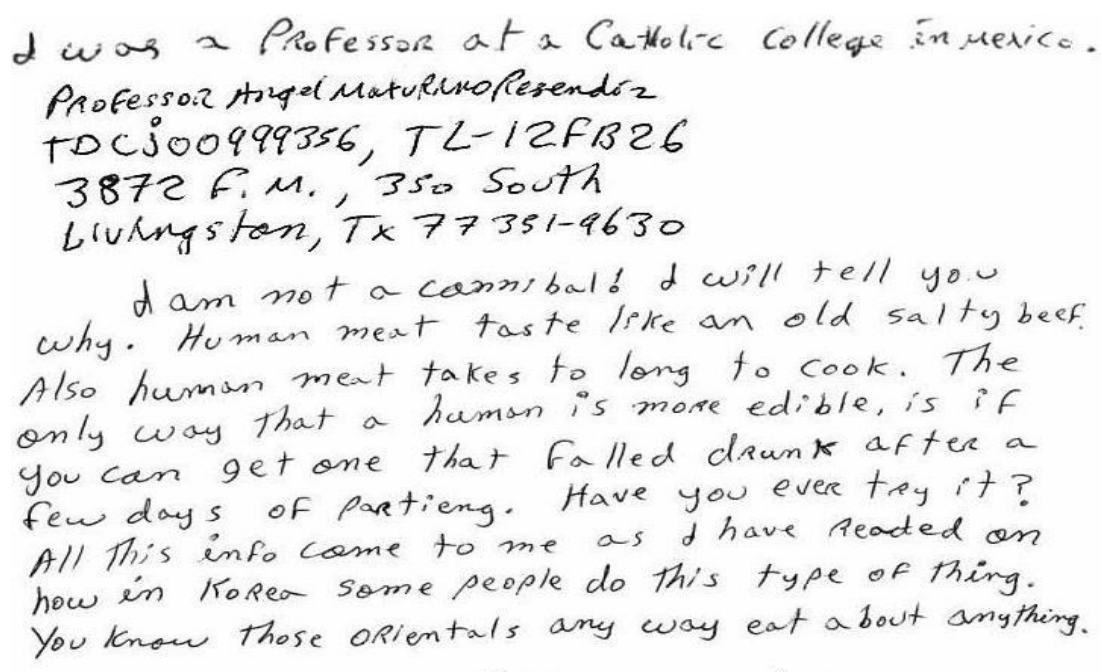

Desse modo, na carta acima, pode-se notar que é revelada uma posição

${ }^{18}$ Artigo publicado no dia 17 de abril de 2012 e acessado para esta pesquisa em 11 de outubro de 2018. Disponível em: <https://ecdotica.com/tren-al-norte/>. Acesso em: 11 out. 2018. 
ambígua de Reséndiz em relação à prática canibal: ao mesmo tempo em que demonstra ter certo temor de que sua pessoa seja associada à figura do praticante de tal atividade, há também certo desejo, talvez relacionado à vontade de provocar horror em seu destinatário, através da riqueza de detalhes a respeito do sabor que teria a carne humana e como melhor "prepará-la", o que aponta para uma rejeição pelo gosto que só pode ser advinda de uma prática já realizada. É importante lembrar que esse é um dos grandes tabus da sociedade na qual ele foi criado, regida pelos supracitados preceitos cristãos (ainda que através da hóstia, seus fiéis estariam consumindo o próprio corpo de Jesus Cristo). Por outro lado, o ritual canibalístico pode ser ligado a aspectos da mística pagã pré-colombiana, os quais ainda remanescem na cultura mexicana, mesmo que isso se dê por meio do sincretismo religioso.

A partir daí, podemos concluir que mesmo que o criminoso afirme veementemente "I am not a cannibal!", como pode ser lido em sua carta, seus atos de estupro antecedidos ou precedidos de assassinatos podem ser vistos, efetivamente, como atos simbólicos de antropofagia, já que se trata, antes de mais nada do consumo e da apropriação de um corpo exterior, tomado para si próprio a partir do uso massacrante da força, o que faz da ação de "devorar" sexualmente uma outra corporalidade um verdadeiro exercício de poder.

À vista disso, Segato propõe duas estruturas que seriam definidoras na análise do ato de estupro. A primeira seria estabelecida através de um "eje vertical", em que o estuprador assume um discurso no qual se constrói um posicionamento punitivo e moralizante, fazendo com que ele se autoatribua a figura do "paladín de la moral social", sendo que "en ese imaginario compartido, el destino de la mujer es ser contenida, censurada, disciplinada, reducida, por el gesto violento de quien reencarna, por medio de este acto, la función soberana" (SEGATO, 2013, p. 23).

A segunda, por sua vez, seria dada a partir de um "eje horizontal", em que o ato não diz mais respeito apenas ao ator e a vítima, mas também a todo um coletivo, isto é, a ação do estupro torna-se-ia um ato de fala, uma interlocução do agressor voltada a seus pares:

[...] les solicita ingreso en su sociedad y, desde esta perspectiva, la mujer violada se comporta como una víctima sacrificial inmolada en un ritual iniciático; compite con ellos, mostrando que merece, por su agresividad y poder 
de muerte, ocupar un lugar en la hermandad viril y hasta adquirir una posición destacada en una fratría que sólo reconoce un lenguaje jerárquico yuna organización piramidal. (SEGATO, 2013, p. 23).

Eva Alterman Blay, no livro Assassinato de mulheres e direitos humanos, ao analisar os instrumentos utilizados para homicídios de pessoas do gênero feminino, no Brasil entre os anos de 1990 e a primeira década do século XXI, por seus próprios companheiros, corrobora com a ideia proposta por Segato de que se trata, antes de tudo, de um ato de demonstração de poder, no qual o objetivo vai além da mera aniquilação da subjetividade da mulher vitimada, de modo que o que é buscado, antes de tudo, é apropriar-se de sua existência, subjetiva e concreta, desenhando a crueldade como um fator intrínseco à ação de dominação desse território-mulher por aquele que a assassina:

\begin{abstract}
$\mathrm{Na}$ metade dos casos, as principais armas utilizadas são as de fogo (revólveres, pistolas, espingardas, metralhadoras e escopetas). Na outra metade, os instrumentos revelam mais do que a intenção de eliminar a companheira:a vontade de violentá-la com crueldade. Utilizaram-se de meios como talhadeira, picareta, tijolo, marreta, fogo, afogamento e asfixia. (BLAY, 2008, p. 93).
\end{abstract}

Dentro disso, os estupros cometidos tanto pelo personagem quanto por Reséndiz, seriam, em realidade, atos de apropriação territorial através do uso da força, isto é, utilizando-se do terror. Vemos aqui um continuum ou aparente etimologia entre território e terror, já notada por Haesbaert (2004), no artigo Território e Multiterritorialidade: um debate.

Desde a origem, o território nasce com uma dupla conotação, material e
simbólica, pois etimologicamente aparece tão próximo de terra-territorium
quanto de terreo-territor (terror, aterrorizar), ou seja, tem a ver com dominação
(jurídico-política) da terra e com a inspiração do terror, do medo -
especialmente para aqueles que, com esta dominação, ficam alijados da
terra, ou no "territorium" são impedidos de entrar. Ao mesmo tempo, por outro
lado, podemos dizer que, para aqueles que têm o privilégio de plenamente
usufruí-lo, o território pode inspirar a identificação (positiva) e a efetiva
"apropriação". (HAESBAERT, 2007, p. 20).

Assim, já desde a concepção do termo território, o uso violento do poder como ferramenta de dominação e apropriação implica em uma relação dominadordominado. O que se dá, nesse caso, seria, dentro dessa perspectiva, uma forma de expansão territorial a partir da dominação do outro, por meio do estupro, e da aniquilação, através do assassinato. Isso se dá principalmente em relação a indivíduos femininos, mas não se deve excluir o caráter vexatório, bem como de imposição e demonstração de controle que as práticas sexuais não consentidas também assumem quando a vítima é um sujeito do gênero masculino, assim como ocorre 
comJesús em sua primeira passagem pelo ambiente penitenciário:

Estaba consciente cuando lo desvistieron y le dieron la vuelta. Quiso gritar cuando sintió la verga de uno de ellos penetrándole el culo, pero ya para entonces sabía que no vendrían a auxiliarlo. Que lo habían puesto intencionalmente en esa celda. Que esa era su manera de darle la bienvenida. Estaba inconsciente cuando lo violó el tercer hombre. (PAZSOLDÁN, 2011, p. 105).

O canibalismo simbólico da cena acima ocorre de modo que a corporalidade de Jesús torna-se o alvo desse processo, em uma relação em que aquele que até então é somente estuprador passa a ser, nesse momento, o sujeito estuprado. Desse modo, além da inversão clara de papéis entre dominador e dominado, há também a configuração do ato de penetração como forma de feminizar o homem e, com isso, subordiná-lo. Isso se dá ainda mais particularmente por conta do contexto carcerário, no qual as disputas por poder são mais perceptíveis ${ }^{19}$.

Um exemplo que se pode encontrar na literatura canônica de uma situação na qual o estupro, com seu caráter de violação anal, seria a máxima desonra para o homem ocidental, afirmando a superioridade daquele que o violenta, encontra-se ao final do conto El Matadero, de Esteban Echeverría. Nele, busca-se efetuar tal ato com um homem de posição política distinta do território do matadouro, tendo a intenção de subjugá-lo. A conclusão do texto indica, todavia, que quem comete esse tipo de infâmia para com homens honrosos como o jovem, seria uma pessoa bárbara, tais quais os federalistas violadores, jamais nobres senhores como os unitários. Com isso, Echeverría reafirma a ideia de que o estuprador seria um monstro, alguém sem o mínimo de racionalidade ${ }^{20}$, posicionando-se de modo que se pode inferir que o sexo anal masculino tratar-se-ia de um ato sobretudo vexatório, efetuado somente através do estupro, ignorando qualquer prazer que dele possa provir.

\footnotetext{
${ }^{19}$ Sobre a questão do ânus na cultura ocidental e, consequentemente, seu posicionamento em relação à sexualidade anal, Alexis Candia evoca Perlongher para tratar das restrições sociais em tornoda sexualidade: "Para Perlongher, sujetar el culo es, en ese sentido, una forma de retener y contener a la sociedad occidental. De ahí que vincule su visión con la postura que mantienen Deleuze y Guattari en el Antiedipo respecto de la privatización, interdicto que apunta a instaurar el poder de la cabeza (logoego-céntrico) sobre el cuerpo y que está condicionada por un miedo ancestral al "contacto del semen con la mierda, de la perla gomosa de la vida con la abyección fecal"." (CANDIA, 2011, p.32).

${ }^{20}$ Echeverría o faz trazendo um posicionamento centralizado na dicotomia entre civilização e barbárie, bastante própria da conjuntura em que está inserido, isto é, na sociedade sul-americana do século XIX. Desse modo, a prática do estupro estaria atrelada à falta de racionalização e, portanto, àbarbárie.
} 
Em relação ao modus operandi dos crimes cometidos por Reséndiz, não é comum que se ocorra o canibalismo (literal), mas sim o hábito de deixar suas vítimas no local em que foi cometido o assassinato. Assim, os corpos de suas vítimas, eram encontrados tais quais estavam após serem mortas, no local fatídico da transgressão (quase sempre suas próprias casas, que haviam sido invadidas ao notar-se algo que pudesse ser dado como falha de segurança, a exemplo de uma janela aberta ou um portão que não estivesse trancado). Isso demonstra, finalmente, não haver indícios de que seus corpos tenham sido consumidos pelo assassino, o que contradiz sua afirmação na carta, deixando em aberto a possibilidade de que haveria, de fato, outras pessoas mortas pelo agressor, cujos crimes não teriam sido ligados a ele pelapolícia.

Segato disserta também sobre a questão do modus operandi dos criminosos que cometem estupros:

\begin{abstract}
Identificar el estilo de un acto violento como se identifica el estilo de un texto nos llevará al perpetrador, en su papel de autor. En este sentido, la firma no es una consecuencia de la deliberación, de la voluntad, sino una consecuencia del propio automatismo de la enunciación: la huella reconocible de un sujeto, de su posición y de sus intereses, en lo que dice, en lo que expresa en palabra o acto. (SEGATO, 2013, p. 22).
\end{abstract}

No que se refere ao personagem Jesús, este segue o pressuposto de não exercer atos que se aproximem do canibalismo, ainda que demonstre uma grande fascinação a respeito do funcionamento do corpo humano, tendo ainda como elemento corriqueiro escrever a palavra "Innombrable" nas paredes com o sangue da vítima, consumir alimentos dos refrigeradores e armários, além de ver fotos e levar consigo seus documentos de identificação em uma tentativa de reconstruir a possível trajetória de vida daquele(a) que havia matado. Para finalizar, quase sempre os automóveis das vítimas tornavam-se o veículo utilizado para que fosse realizadacom êxito sua fuga do local do crime. À vista disso, todos esses dados levam-nos a concluir que Jesús deixava nos locais dos crimes sua "assinatura", isto é, a "firma"do estuprador.

Além disso, o personagem envolve-se diversas vezes com mulheres que trabalham como prostitutas, as quais são também habitantes de espaços nãonormativos e trazem consigo não apenas as marcas da violência de classe, como também de gênero. Isso faz com que o tratamento que o personagem dá a elas seja agressivo, já que ele demonstra ter como preferência "atarla, darle golpes en el culo, 
bofetadas en la mejilla" (PAZ-SOLDÁN, 2011, p. 79). Jesús continua indo ainda além e demonstrando sexualmente seu descontrole com tudo aquilo o cerca: "En una ocasión, borracho y drogado, la había mordido en el cuello hasta hacerla sangrar. Ella se asustó. Él le explicó que cuando se entregaba de verdad no conocía límites" (PAZSOLDÁN, 2011, p. 79).

A condição delinquencial de Jesús afeta grande parte das pessoas que conformam suas relações de convívio, principalmente aquelas do gênero feminino e que são imigrantes em condições de marginalização social. Há nisso a construção de umimaginário coletivo no qual a sociedade trata tais sujeitos como delinquentes e, quando seguem o único caminho esperado em um ambiente delituoso, são aprisionadas e uma vez mais afastadas, encaminhadas para outra heterotopia, dessa vez sob o domínio pleno do braço controlador do Estado. Assim, o imigrante ilegal deve tomar uma dura decisão, segundo explica Glória Anzaldúa, em sua obra célebre, Borderlands: "Los trabajadores mestizos atrapados entre ser tratados como delincuentes y poder comer" (ANZALDÚA, 1987, p. 53).

Dessa forma, sua maneira de se relacionar sexualmente, não conhecendo limites ao entregar-se, equipara-se a seu próprio construto ao cometer assassinatos, afinal, é possível inferir, em uma leitura mais atenta, que ele possa transitar desde o autocontrole sobre suas ações ao mais completo descomedimento, tudo isso em um breve intervalo de tempo. O que se verifica é a possibilidade de um processo de transferência da responsabilidade das condutas, já que em relação aos primeiros crimes por ele cometidos, não haveria um sujeito que fizesse de fato a ação (uma vez mais, dentro de sua perspectiva, ele estaria fora de si, assim como em suas experiências sexuais, sendo motivadoras as substâncias alcoólicas e/ou entorpecentesque havia consumido e, até mesmo, a justificativa de que estava com fome e necessitava entrar em uma casa para comer, assim como costumava fazer após assassinar suas vítimas). Depois disso, a culpabilidade seria transmitida para a entidadeque denomina como Inominável, trazendo um elemento religioso em sua refutação.

Por fim, podemos afirmar ainda mais um elemento próprio da subjetividade conflituosa de Jesús, uma vez que sua mente é permeada de desejos incestuosos, como a vontade sexual que sente em relação a sua irmã Maria Luísa, estabelece uma relação de fronteiras íntimas e externas, afinal o incesto também pressupõe a 
passagem de um limite de organização social.

Com isso, é possível concluir que não se trata de um canibalismo literal, como diz a carta, mas simbólico, conforme trabalha Segato. A partir dessa leitura, o corpo torna-se um território invadido e afrontado.

\subsection{Heterotopia e espaços delinquenciais}

Cabe frisar que a trama da linha narrativa de Norte aqui trabalhada centra-se sobretudo nas transformações que o personagem de Jesús passa ao longo de seus deslocamentos e nos impactos dessas mudanças em sua vida, especialmente sendo ele um sujeito delinquente atravessador de fronteiras. Aquele que havia sido um jovem franzino, tímido e de poucas ações torna-se um assassino sanguinário, o qual chega a alcançar em um determinado momento o topo da lista de fugitivos mais procurados dos Estados Unidos: "Rafael se enteró al final del dia que el FBI había puesto al Railroad Killer en la lista de los más buscados [...]. Estaba en el primer puesto, desbancaba a Osama bin Laden" (PAZ-SOLDÁN, 2011, p. 234).

É por meio da narração desse processo de atravessar fronteiras físicas e simbólicas que se evidenciam ainda mais as repercussões dos atos de delinquência do personagem, os quais podem ser analisados tanto através da ótica do rompimento de fronteiras, quanto pelo deslocamento entre territórios que esses atos supõem. Assim, no que diz respeito à espacialidade física, isso se dá ao atravessar a fronteira geopolítica que divide México e Estados Unidos, mas também pode ser visto em situações cujo caráter é abstrato. Nestas, tais atos conformariam novos territórios e, consequentemente, a necessidade de se territorializar, isto é, referindo-se aos modos como, desde a própria idiossincrasia de cada sujeito, cada um lida com os espaços e ali estabelece vínculos, convertendo-os em territorialidade. Tais formas de territorialização, no caso dos locais pelos quais o personagem transita, são realizadas comou sem a permissão normatizante do Estado, uma vez que sai desse território para tornar-se marginal. Assim, uma das maneiras de transformar um espaço em territórioé através do político. A lei do Estado converte o espaço em território e o delinquenteé todo aquele que transgride essa lei.

A estratégia de Jesús para fazê-lo é através da reprodução do padrão próprio das pessoas que cometem atos de delinquência, ou seja, para manter-se em segurança desloca-se constantemente entre identidades, criando codinomes (o FBI, desavisadamente, busca Jesús sob seu pseudônimo de Gonzalez Reyle), e entre 
espaços, quando em fuga após o crime. Essencialmente, a maior fronteira abstrata é rompida já no primeiro delito, ao assassinar a prostituta guatemalteca Suzy, o qual o torna um delinquente, transpassando-o para o outro lado da sociedade, o lado fora da lei. Assim, a delinquência mobiliza a apropriação de um espaço que vai além do Estado e de suas normas, conformando outra realidade coletiva, pertinente somente àqueles que dela participam. Jesús integra-se nesse sentido à figura de marginal, pondo-se à margem dos pressupostos sociais e juntando-se àqueles que compõem esse território externo à legalidade do Estado, de modo que ainda que seja evidente o caráter solitário desse ato de deslocamento marginal, é relevante pautar que se trata, como dito acima, de outra configuração de inscrição territorial.

Dentro da lógica do personagem, a partir do momento em que Jesús comete o primeiro assassinato mencionado acima, ocorre a sua subscrição social e pessoal na categoria de assassino, lugar do qual ele já não se moverá mais, senão para frente. Para ele, já não há mais maneira voltar para a posição inicial, o delito já foi cometido e, após ser apresentado à entidade "Inominável”, torna-se sua função enquanto “ángel vengador" 21 transformar-se naquele que limparia a humanidade de seus pecados, sendo que para tal seria utilizada a violência mortífera. Desse modo,o aspecto religioso seria uma maneira delirante de inscrever seus assassinatos como atos de serviço a essa comunidade que, no nível do real, ele afronta enquanto delinquente.

Segundo ele nos dá a entender, é justamente pela ausência de "una señal salvadora, una iglesia en la cual encontrarse con el rostro familiar del padre Joe" (PAZSOLDÁN, 2011, p. 51) que há apenas o mergulho, cada vez mais profundo, do personagem na criminalidade e, consequentemente, nos espaços nos quais ela é concebida e efetivada. É dessa forma que a delinquência de Jesús pode também ser entendida no plano do religioso-místico, ou seja, sua desterritorialização da lei do Estado é reterritorializada na violência, a qual busca seu fundamento na esfera do místico.

Dessa forma, o personagem constrói uma parte significativa de sua territorialidade em bares clandestinos, nos quais efetua um consumo descomedido de entorpecentes, em prostíbulos baratos e em hotéis miseráveis, cujos dormitórios são retratados de modo a evidenciar a atmosfera de desleixo: "una alfombra picada

${ }^{21}$ Conforme Jesús repete inúmeras vezes e sobre o qual dissertaremos com mais atenção na seção seguinte. 
por quemaduras de cigarrillos, una tina oxidada" (PAZ-SOLDÁN, 2011, p. 56). Esses ambientes, quando somados aos dos presídios nos quais o personagem é diversas vezes recluso, compõem o que Foucault (1984), no texto De los espacios otros, chama de heterotopos. A partir disso, podemos concluir que o caso desses locais pelos quais transita Jesús tratar-se-iam de heterotopias de desviación, segundo a terminologia utilizada pelo autor:

[...] aquellas en las que se ubican los individuos cuyo comportamiento está desviado con respecto a la media o a la norma exigida. Son las casas de reposo, las clínicas psiquiátricas; son, por supuesto, las prisiones, y debería agregarse los geriátricos, que están de alguna manera en el límite de la heterotopía de crisis y de la heterotopía de desviación, ya que, después de todo, la vejez es una crisis, pero igualmente una desviación, porque en nuestra sociedad, donde el tiempo libre se opone al tiempo de trabajo, el no hacer nada es una especie de desviación. (FOUCAULT, 1984, p. 3-4).

Retomamos, assim, a problemática do corpo de modo a mobilizá-la em função de sua relação com o território, uma vez que a corporalidade está intimamente imbricada com a experiência violenta que é viver em tais espaços. Atos violentos cometidos por delinquentes, devemos novamente frisar, como assassinatos ou torturas físicas, violam, fundamentalmente, o espaço corporal do indivíduo que os sofre. Trata-se, portanto, antes de tudo, de um ataque à materialidade da vítima, isto é, à sua existência concreta nesse mundo. Dessa forma, a questão da corporalidade aparece atrelada a uma sociedade coercitiva, criadora de heterotopos nos quais seus desviantes procuram se abrigar.

Com isso, podemos sintetizar a delinquência cometida pelo personagem como o rompimento violento com as estruturas compulsórias que regem a sociedade, as quais são materializadas através de leis e regras, criadas e fiscalizadas por instituições que vão desde os governos dos países às forças policiais por eles comandadas, representadas em Norte na figura de Rafael Fernandez. Ao desrespeitar tais determinações, um sujeito desloca-se automaticamente a categoria de delinquente, por conta disso tal termo é muitas vezes utilizado como sinônimo de marginal, uma vez que ele passaria a estar à margem da sociedade, tanto fisicamente (habitando os heterotopos) quanto metaforicamente.

$\mathrm{O}$ atravessar fronteiras de Jesús enquanto delinquente, no qual ele passa do território do Estado ao território da criminalidade, ou seja, àquele que se constrói à margem, ressignifica seu atravessar de fronteiras enquanto sujeito migrante. Dessa forma, Jesús cruza conscientemente a fronteira entre os países e utiliza livremente as estruturas básicas culturais de cada um deles, chegando a aprender a língua 
inglesa para utilizá-la em momentos convenientes, mas não parece ter consciência das marcas que Ihe trariam ao adentrar o âmbito da delinquência, já que a partir disso surge a necessidade de abandonar a territorialidade que havia configurado em sua cidade natal, Villa Ahumada (o próprio nome da cidade, que em tradução livre significaria "Vila Esfumaçada", dá-nos uma pista da situação lúgubre daqueles que a habitam $)^{22}$.

Assim, os deslocamentos de Jesús, os caminhos por ele percorridos e os conflitos em relação às normas sociais ali presentes se tornam figurações desse personagem. Jesús é um assassino, um delirante "ángel vengador" o qual acredita que sua postura desviante é, na verdade, heroica. Porém, é também um jovem de baixa escolaridade, um imigrante deslocado, detentor de desejos confusos, cujo núcleo familiar foi deteriorado por conta de pais ausentes e uma relação unilateralmente incestuosa com sua irmã, Maria Luísa, a qual o rechaça veementemente. Além disso, seus pais são da mesma forma sujeitos submersos nas problemáticas da vida em uma sociedade que se conforma no lado desvalido da fronteira, sendo obrigados a submeterem-se a trabalhos desgastantes e ao distanciamento dos filhos por conta da situação sócio-econômica em que se encaixam, principalmente no que se refereà imigração como forma quase que exclusiva de escape ao desemprego.

O personagem desenvolve, desse modo, uma espécie de microcosmos de proteção, ou em outras palavras, uma forma particular de lidar com o mundo em que vive de forma a buscar sua autopreservação, especialmente dada sua condição enquanto sujeito que delinque e necessita, portanto, fugir. John E. Douglas (1992), em seus estudos sobre tendências de comportamento de criminosos, fala particularmente do caso de Ángel, que serviu de inspiração para o personagem, abordando sua preferência pelas vias de trem: "As a fugitive, he may go to an area where he feels comfortable, the way alleged railroad killer Angel Maturino Reséndiz, also known as Rafael Reséndez-Ramirez, stuck to the tracks". (DOUGLAS, 1992, p. 478).

Dado isso, apesar da evidente predileção pelas vias ferroviárias, o que é justificável, uma vez que o trem torna-se veículo auxiliar para a fuga, Jesús demonstra

\footnotetext{
22 Tal qual ocorre com os residentes da cidade de Luvina, criada ficcionalmente em um conto de mesmo nome do também mexicano Rulfo, autor que é bastante aludido, direta e indiretamente, nas narrativas cujos personagens centrais são Martín e Michelle.
} 
não se acomodar de fato em qualquer espaço físico restrito. No momento em que decide fixar residência dentro do perímetro de um município, isto é, em certa altura de sua vida opta por contruir morada em uma cidade ao casar-se e comprar uma casa, não abandona a escolha inicial de ter a liberdade de poder deslocar-se rumoao desconhecido (quando possível, dados os seus períodos em encarceramento).

Isso se dá porque o personagem possui a segurança de que ao embarcar ilegalmente nos trens, os quais ele conhece tão bem, levá-lo-iam de volta à vida que havia constituído em terras mexicanas. O pesquisador José Manuel Trabado Cabado disserta sobre esse movimento de vagar sem uma direção específica, tão caro a Jesús durante suas viagens rumo ao norte, nas quais busca, antes de tudo, encontrar seu próprio "norte", isto é, encontrar-se a si mesmo: "Deambular es una formade buscar el vacío, el sin sentido [...] Vagar sin rumbo es vaciarse, desprenderse dela identidad, del pensar. [...] La deslocalización está estrechamente emparentada con la anulación de la identidad" (CABADO, 2010, p. 535).

Jesús constrói sua própria personalidade, seus traços e trejeitos a partir dessa subjetividade nômade, permeada de idas e vindas por diversos heterotopos. Suas ações, ainda que muitas vezes motivadas por delírios de origem desconhecida, tornam-se, com isso, frutos dessa sua forma de lidar com o mundo. Afinal de contas, o personagem transpassa-se ao "mundo normal" apenas para cometer seus assassinatos e nada mais do que isso, já que para ele a vida perfeitamente construída pela ideia do sonho americano, além de lhe ser completamente alheia ou, segundo o termo que utiliza, "prestada" Ihe dava nojo:

[...] por un momento se imaginó con una vida prestada en ese país que no era el suyo, recibiendo amigos durante las noches, cortando el césped los sábados por la mañana, viendo televisión con su mujer e hijos los domingos por la noche, un perro o un gato a sus faldas. Le dió asco esa fantasía, tener esa vida. (PAZ-SOLDÁN, 2011, p. 82).

O interessante é que a vida que descreve como "prestada" em um país "que no era el suyo" é bastante similar à vida do ranger Rafael Fernandez, marcando uma oposição entre os dois personagens e mostrando-nos que Jesús não concorda com as normas sociais vigentes, de modo que estaria tão imerso no âmbito delinquencial também como forma de repulsa às convenções sociais. Ainda assim, é importante frisar a diferença que há entre aquilo que Jesús e imagina e o que Fernandez, de fato, realizou.

A tranquilidade de estar sozinho que o personagem demonstra, durante suas 
viagens de trem, vem carregada de significado a partir da imagem do vento "golpeando" o personagem no rosto, a qual não é violenta, mas representativa de liberdade, visto que se trata, inclusive, de um símbolo frequentemente revisitado pelo imaginário coletivo para essa finalidade, sendo a liberdade justamente aquilo que é buscado pelo personagem. Há, porém, violência na situação de constante preocupação de ser capturado pelos agentes da imigração nos momentos em que o trem aproxima-se das estações ao longo de seu trajeto. O não lugar do personagem na sociedade faz, assim, com que ele passe constantemente por processos de subscrição nos territórios heterotópicos, os quais se autorregulam para além dos parâmetros estatais, conformando suas próprias regras de conduta.

Dessa forma, ressaltamos que as personagens do livro, inspiradas ou não em histórias reais, são retratos de pessoas de carne e osso que sofreram e sofrem no próprio corpo as consequências dos deslocamentos e das relações de poder aí subscritas. O caso de Jesús é, com isso, um tanto quanto particular, uma vez que nele ocorre uma relação muito específica com o espaço que ocupa: ele possui pleno domínio das estruturas de controle que atuam na fronteira entre México e Estados Unidos, cruzando-a sempre que the parece interessante e aproveitando tal conhecimento para ressignificar o atravessar fronteiras de modo a torná-lo parte de sua conduta criminosa (assim como ocorre no andar sem rumo próprio do delinquente). Há também uma particularidade no afastamento forçado por meio do encarceramento, o qual, apesar de limitar sua liberdade, transforma-se em um deambular por meio da escrita.

\subsection{Criminalidade e misticismo}

Ao se inscrever nas categorias de estuprador e assassino, Jesús leva ao ápice toda a violência física e psicológica que o cerca. O contexto da imigração e da construção de territórios para Jesús é diverso daqueles referentes aos sujeitos cumpridores da lei, assim como também é a forma como sua história é contada. A narração é feita, como vimos, sem excessos, uma vez que seus próprios atos já constituiriam por si só excessivos. Assim que o narrador evita qualquer divagação ou sentimentalismo, relatando com frieza as ações cruéis e atemorizantes do personagem para com os demais. Obviamente, a forma como Jesús aproveita seu saber se deslocar (um saber próprio do migrante) para a delinquência, ainda que 
constitua parte de sua identidade, não reflete a realidade da imensa quantidade de pessoas que imigram todos os dias para outros países. Isso se dá, especialmente, por conta da forma como o personagem usa o conhecimento que possui sobre atravessar fronteiras de forma subversiva, isto é, para o benefício da própria delinquência.

O personagem torna-se devoto de uma deidade ficctícia que é designada como Innombrable, a qual aparece novamente em Los días de la peste (2017), também de Paz Soldán, mas neste trata-se de uma figura feminina, diferentemente do que ocorre em Norte, obra em que se utiliza o artigo masculino definido para indicá-la. Apesar dessa diferença de gênero, em ambos a divindade é símbolo da vingança e da violência, o que pode ser visto em uma breve descrição de sua imagem no primeiro romance: "Una diosa vengativa, representada en todas partes con un cuchillo en la boca" (PAZ-SOLDÁN, 2017, p. 154), e é também divulgada fortemente no ambiente carcerário. Jesús, após sua conversão em uma de suas muitas passagens pelo sistema penitenciário, passa a escrever cadernos místicos, os quais ele denomina Libro de las Revelaciones.

Como sabemos, o conceito de misticismo traz consigo a forte presença da crença em um elemento sobrenatural e, a partir disso, há com frequência a ideia de um acesso direto à comunicação com a divindade cultuada por tal sujeito místico, o qual acredita ser privilegiado. Com isso, é possível perceber que é dada a máxima importância ao Innombrable (no gênero masculino, visto que o caráter misógino de Jesús, trabalhado na seção anterior, dificilmente lhe permitiria o culto a uma divindade feminina). O personagem encontra em tal figura uma ferramenta de orientação e passa a cultuá-lo com extrema devoção. Em seus delírios místicos, ele acredita que ao cometer assassinatos estaria, na verdade, favorecendo e servindo aquele que acredita ser o verdadeiro Deus.

Interessantemente, o nome Jesús María José, escolhido pelo autor para o personagem carrega em si o símbolo máximo da doutrina cristã ao representar a bíblica Sagrada Família (parecendo-nos também haver uma dose de sarcasmo).Com isso, traça-se uma relação entre o Cristianismo e o culto ao Innombrable, explicado por um dos personagens em Los días de la peste (2017):

Solo recordó que la diosa se había vuelto Innombrable hacía poco. La prohibición del culto quizás no lograría hacerla desaparecer, pero al menos debía hacerla nuevamente nombrable por todos. Así se perdería uno delos poderes de los cuales derivaba su ascendiente. Una influencia que provenía del catolicismo de los colonizadores. Porque el Juez estaba seguro deque la confusa dualidad de la diosa, el hecho de que Ma Estrella fuera una 
representante de la verdadera e innombrable diosa, provenía de la Santísima Trinidad. (PAZ-SOLDÁN, 2017, p. 154-155).

Tal misticismo é manifestado dentro do heterotopo que se configura no espaço penitenciário, cuja territorialidade é baseada, sobretudo em relações conflituosas de poder tanto entre internos, quanto em relação a estes e à equipe dirigente. Pensando nisso, na obra literária, o personagem Jesús demonstra ter certa fama, inclusive em relação àqueles que se encontram fora de tais espaços, o que se dá, por exemplo, pela venda de mechas de seu cabelo, de modo similar ao que ocorre com as relíquias de santo. No epílogo, onde tal situação é narrada, o personagem interpreta a atitude de seus compradores como insana, provavelmente porque se tivesse a oportunidade certamente os teria matado, demonstrando o caráter irônico de toda essa situação: "Vendía su firma por cincuenta dólares. Vendía mechones de su cabello. Llegó a vender los callos de sus pies. Pinches gringos, estaban retelocos." (PAZ-SOLDÁN, 2011, p. 272).

Além disso, dentro do espaço de heterotopia penitenciária a alcunha de assassino possui uma carga distinta de sê-lo em outros espaços sociais normatizados, como em uma escola ou uma igreja. Para adentrar esses espaços tidos como "normais" (uma vez que estão subscritos à norma) é preciso que o personagem o faça segredo, o que corrobora com a ideia de que os ambientes carcerários possuem uma lógica própria de funcionamento, a qual por não ser condizente com a de seu exterior, faz com que seus ex-habitantes, quando libertos ou evadidos por meio de fugas, tenham que diversas vezes omitir das demais pessoas seu percurso de vida. Daí advém a reação do personagem ao ser aceito como professor de inglês em uma pequena escola católica no México: "Jesús sonrió: si supieran" (PAZ-SOLDÁN, 2011, p. 138).

Tal sorriso, reação à inocência daqueles que o haviam aceitado, diz respeito também à expressão corporal que o personagem passa a adquirir no breve momento em que retorna ao México, após um largo período aprisionado, em busca de ingressar na pequena sociedade do povoado de Rodeo. Assim, ele adota o anonimato para que ali pudesse "aislarse del mundo, perderse. Comenzar una nueva vida" (PAZ-SOLDÁN, 2011, p. 137). Nessa nova conformação territorial, Jesús sente-se mais tranquilo em meio à anonimidade: "Dormía mejor y habían desaparecido lasmanchas rojas en sus mejillas" (PAZ-SOLDÁN, 2011, p. 138).

O pacato local, todavia, não traz para o personagem a calma desejada, o 
chamado místico torna-se demasiado forte, fazendo com que o breve processo de territorialização no mundo exterior ao penitenciário seja interrompido. É em meio à multiplicidade de territórios que o personagem, ao não pertencer a nenhum lugar, constrói a própria subjetividade e faz com que sua missão mística, recebida pouco tempo antesem uma espécie de batismo macabro no ambiente da prisão, prossiga: "el viaje debía continuar. No era para él eso de quedarse en un lugar por el resto de su vida" (PAZ-SOLDÁN, 2011, p. 155).

Assim, apesar da frequência de seus delírios, Jesús percebe que precisa fazer uso da razão para ser bem-sucedido em seu objetivo, isto é, cometer o maior número possível de assassinatos. Para tal, desenvolve um plano, em que deveria ter uma relação estável e casa-se sem amor com Renata, atendente da pequena farmácia da cidade apenas para manter as aparências sociais. Em meio a transes proféticos, anuncia veementemente que sua sequência de assassinatos não teria fim, já que "Llegará el día del Juicio Final, soy el ángel soy Dios soy. KILL THEM ALL." (PAZSOLDÁN, 2011, p. 156). O único modo aparente de parar seu frenesi aniquilador é por meio da intervenção estatal, o que pode ser encontrado nas últimas linhas de Norte, nas quais se narra a execução de sua sentença de morte: "Jesús sintióuna leve picadura. Un instante después estaba muerto”. (PAZ-SOLDÁN, 2011, p. 280). Para ele, porém, estava claro que a injeção letal que receberia não era um caso de justiça, uma vez que afirma veementemente: "La justicia soy yo" (PAZ- SOLDÁN, 2011, p. 271), promovendo uma descrença no papel do Estado e elevando a si mesmo a uma categoria maior do que a de juiz dos homens, a de juiz divino.

O número elevado de assassinatos e violações torna-se ainda mais complexo quando se entrelaça ao campo do misticismo. Ángel Marturino Reséndiz revela, com tranquilidade, durante a série de entrevistas que o jornalista britânico Alex Hannaford ${ }^{23}$ realiza com ele, ter cometido mais crimes do que aqueles pelos quais estava sendo condenado e que haveria um número considerável de pessoas inocentes que estariam sendo erroneamente criminalizadas por atos que, em realidade, ele havia sido o responsável. Tal afirmação foi feita três anos antes da execução do serial killer pelo

\footnotetext{
${ }^{23}$ Alex Hannaford realizou uma série de entrevistas gravadas com Ángel Marturino Résendiz no ano de 2003, as quais foram dirigidas e transformadas em podcasts por Peter Sale para a plataforma de distribuição e divulgação de podcasts AudioBoom entre outubro de 2018 e fevereiro de 2019. Tal conteúdo recebeu o nome Dead Man Talking, afinal na época de publicação o criminoso já havia recebido a injeção letal que o levou à morte, a qual foi dada no dia 27 de junho de 2006.
} 
Estado, durante sua prisão no complexo penitenciário de Huntsville na cidade fronteiriça estadunidense do Texas, onde a maior parte de seus crimes havia sido cometida.

Independente da veracidade ou não de seu relato, é importante que seja ressaltado o fato de ambos, personagem e inspirador, acreditarem ter sido enviados para combater o mal de toda a humanidade, o que pode ser visto como um delírio místico/profético. Isso faz com tal afirmação torne-se bastante plausível, em sua percepção de realidade, uma vez que nela assume-se a ideia de que todas as vidas teriam sido corrompidas pelo pecado e deveriam, por conta disso, terem suas existências eliminadas. Portanto, não é nenhuma surpresa que Reséndiz alegue ter cometido um grande número de mortes, visto que quanto maior é o número de óbitos alcançados, maior seria sua glória por ter contribuído fielmente para sua causa.

A explicação da motivação dos atos criminais é bastante discutida pela psicanálise. Segundo ela, toda e qualquer ação humana estaria, antes de tudo, fundamentada em uma dinâmica inconsciente, de modo que dela seria derivado um desejo que não obedece ao campo da lógica racional. Seguindo essa premissa, há a possibilidade de que tal entidade talvez se trate mais de uma busca por tornar consciente e exterior algo que para o personagem é, em realidade, subjetivo e mistificado.

Aguilera-Torrado disserta a respeito da importância que possui o chamado "rasgo de excepción", o qual estaria relacionado à personalidade de pessoas que têm tendências a cometer atos delinquenciais:

La clínica psicoanalítica nos revela que el rasgo de excepción se da gracias a un placer fácil e inmediato que en la teoría psicoanalítica se llama goce. La dinámica psíquica del ser excepcional está sostenida por el hecho de haber sufrido tempranamente una injusticia, que lo obligó a someterse a un padecimiento, el cual lleva al sujeto a creer que se le debe eximir del cumplimiento de cualquier norma; el ser excepcional reclama el derecho de ser eximido de la norma, a manera de un derecho de resarcimiento, como si tratara de reclamar los beneficios de un seguro o una póliza de indemnización.(AGUILERA-TORRADO, 2010, p. 343).

Nesse ponto, devemos considerar que Jesús percebe a si mesmo enquanto um ser supernatural, o que o põe ao encontro da perspectiva do rasgo de exceção, de modo que, em sua concepção, ele seria distinto das demais pessoas, não devendo seguir os mesmos paradigmas e leis que regem os demais indivíduos. Dentro desse posicionamento, manifestam-se traumas e complicações experienciados durante a infância, os quais podem ter sido adquiridos, por exemplo, pela ausência parental, não 
apenas de seus pais biológicos, mas também por aqueles que se configuram enquanto metáfora, isto é, uma paternidade simbólica.

Tal alegoria pode ser representada, no caso do sujeito imigrante, pelo próprio Estado de origem em conflito com aquele em que se ingressa, principalmente quando se trata da aquisição de uma nova língua e da construção de uma identidade bilíngue. Para Melman, essa condição refere-se a uma superposição de figuras paternas, assim havendo um conflito intrínseco àquele que imigra, pois além do caráter sacrificial da troca de representação paterna, "é preciso ainda que seja simbolicamente aceito pelo Outro o dom que lhe é oferecido" (MELMAN, 1992, p. 26).

É dessa forma que Jesús parece estar constantemente tentando negar ambos os lados da fronteira geofísica ao mesmo tempo em que busca utilizá-los para benefício próprio, o que é feito através do conhecimento bilíngue e da maneira de deslocar-se utilizando os trens como meio de transporte.

Há sempre há uma relação inerente entre língua e espacialidade para a configuração da territorialidade. Ao longo da narrativa de Jesús isso se dá através de marcas fortes de construções gramaticais próprias da linguagem oral, atingindo inclusive, e evidentemente, a produção escrita do personagem, a qual se desenvolve em um conjunto de cadernos profanos que escreve com o objetivo explicar a missão que o Innombrable Ihe havia designado: "Kill them all'. A sentença, que vira uma espécie de leitmotiv em sua trajetória de crimes, está interessantemente na língua inglesa, em oposição a sua nativa língua espanhola, marcando possivelmente que o alvo principal de sua conduta violenta deve ser os cidadãos estadunidenses, o que acaba por ser comprovado, já que a maior parte de seus crimes são realizados do outro lado da fronteira que separa os países.

Ademais, verifica-se como recurso narrativo a conformação de uma condição linguística similar a um argot, utilizado para representar a particularidade dessas territórios heterotópicos, como os das instituições penitenciárias pelas quais passa Jesús, até o momento que é condenado à morte e, por conta disso, executado. Essas fortes marcas de oralidade, as quais têm como objetivo uma construção mais fidedigna do personagem no que se refere, como vimos, a seu baixo grau de escolarização e à sua relação com a escrita, são perceptíveis, por exemplo, no seguinte trecho do romance: 
la voz del Innombrable y luego copiaba en un cuaderno las frases que le había dictado. "ELIMINAR A TODOS LOS IMBECILES. Las mujeres y los niños primero. Las MUJERES y los niños PRImero. Mitad hombre mitad ángel. Hombreangelhombreangel". (PAZ-SOLDÁN, 2011, p. 133).

Aqui é possível perceber também a referência a outra recorrência na narrativa: a forma como o personagem lida com seus sonhos e alucinações (dita como "sonhar com os olhos despertos"), transformando-os em escrita, os quais são frequentemente compostos por cenas violentas, envolvendo elementos fisiológicos como a presença de sangue e lágrimas, bem como instrumentos que podem ser utilizados para provocar danos materiais à corporalidade, sendo facas e revólveres os mais relevantes entre esses objetos, visto que são também as armas que utiliza para cometer seus assassinatos. Posto isso, podemos considerar que a interpretação de tais sonhos e alucinações (pertencentes ao campo do inconsciente) são também passíveis de formas de territorialização, afinal carregam consigo elementos estruturais da vida daquele que os comporta, no caso o personagem Jesús, porém de forma que os possam ressignificar dentro desse novo contexto tão íntimo e solipsista que é o território da mente humana.

É desse modo que a escrita de Jesús torna-se, também, uma forma de existir enquanto sujeito, de entender melhor e divulgar suas ideias (ainda que não tenha disseminado seus cadernos entre as pessoas, ele os esconde em pontos distintos dos diversos locais pelos quais passa para, finalmente, os recolher e entregar à sua irmã, Maria Luísa), assim como de fazer resistência ao Estado e ao aprisionamento, além de construir uma autoimagem diferenciada, já que acredita ser uma espécie de profeta e sua obra algo parecida aos livros religiosos, ainda que, de algum modo, às avessas.

Goffman fala sobre a prática da escrita nos contextos das instituições totais, abordando o caso dos boletins internos, muitas vezes produzidos pelos próprios internos, em situações como prisões e hospitais psiquiátricos:

[...] existe material que pode refletir uma interpretação editorial. Aqui encontramos: notícias do mundo externo que têm relação com a posição social e legal de internados e ex-internados, acompanhadas por comentários adequados; poesia, contos e ensaios originais; editoriais. A redação cabe aos internados, mas exprime a interpretação oficial das funções da instituição, a teoria da equipe dirigente quanto à natureza humana, urna versão idealizada das relações entre a equipe dirigente e os internados, e a posição que um convertido ideal deveria aceitar - em resumo, apresenta a linha de ação da instituição. (GOFFMAN, 1961, p. 86).

Desse modo, ainda que o conteúdo seja produzido pelas pessoas privadas de liberdade, a intervenção da equipe dirigente é constante, até mesmo quando se tratam de escritas auspiciadas pela instituição, trazendo consigo o peso da censura e os 
limites promovidos pelo estado, afinal tal material seria divulgado entre os demais internos e muitas vezes, até mesmo, em outras instalações similares. Isso, porém, não é justificativa para que tais atitudes ocorram, visto que até mesmo as correspondências privadas também costumam ser expostas aos olhos atentos dos vigilantes, afinal toda e qualquer informação deve ser criteriosamente controlada: "Nas prisões, onde as cartas são frequentemente limitadas quanto à frequência, ao conteúdo e ao destinatário, é possível empregar códigos." (GOFFMAN, 1961, p. 212).

Daí que podemos interpretar que a vigilância de tais produções é frequentemente ligada à exposição destas pessoas a outras. No caso do personagem, seus cadernos mantêm-se intactos supostamente por conta dos esconderijos que encontra, assim como por assemelharem-se (ainda que não pareça ser sua intenção) ao gênero discursivo do diário, no qual não se busca a divulgação das informações, mas uma exteriorização de seus pensamentos e sentimentos íntimos.

A escrita de Jesús configura-se um território e se torna sua forma de seguir a única realidade que conhece: a do deslocamento. Lembrando que isso vem também por meio de marcas hereditárias, sendo seus próprios pais sujeitos migrantes. Além disso, por estar em constante passagem por heterotopos, Jesús recusa o Estado e, consequentemente, a religião cristã, com o qual mantém uma íntima relação, segundo disserta Amaral:

A ideia de um deus único e a hierarquização da Igreja Católica são fatores que favorecem o inevitável embricamento entre religião e Estado. Este aparelhamento do governo por parte do Cristianismo faz com que a religião exerça não apenas sua função de fé e misticismo, mas seja também um dispositivo de punição e ordem social. (AMARAL, 2016, p. 5).

Em suma, podemos pensar que a criação de uma nova espécie de religião, sendo Jesús não apenas seu fiel seguidor como, em sua concepção, o "ángel vengador", cuja função seria de disseminar a palavra do Innombrable (através dos cadernos) e limpar a terra de pecado (através do assassinato de todos os pecadores), é também um desvinculamento em relação à religião do Estado, visto que para o DeusEstado, trata-se apenas de um delinquente a ser institucionalizado, a espera de ser, finalmente, eliminado. O personagem tenta extrair-se do território hermético que se constitui na prisão por meio de sua escrita, a qual se torna uma nova maneirade deambular, trazendo nela o elemento místico, tão importante para a construçãoda subjetividade do personagem. Entrelaçando, por meio da escrita, os territórios místico 
e prisional e, com isso, tornando-se uma forma de territorialidade. 


\section{Capítulo 3. Michelle: o território do campus universitário}

Every moment happens twice: inside andoutside, and they are two different histories.

(Zadie Smith, 2003, p. 299).

Tal qual Comênio ${ }^{24}$, que procurou conceber uma Didática Magna universal, a partir da qual qualquer pessoa, em qualquer lugar e em qualquer momento histórico poderia aprender qualquer assunto, Fabián Colamarino, personagem de Norte, empreende sua cruzada buscando "Una teoría unificadora capaz de explicar toda la literatura latinoamericana." (PAZ-SOLDÁN, 2011, p. 67). Apesar do recorte regional, a intensão de reunir em um só ponto uma gama complexa de autores, obras e movimentos, além de suas diversas nações originárias, cada qual com sua própria historicidade, parece ser uma missão (quase) impossível. Não à toa, essa se torna uma das razões de sua constante paranoia. É praticamente desnecessário dizer o óbvio:o objetivo não é concluído, tampouco concluível. A obra, caso não fosse uma "utopía" (PAZ-SOLDÁN, 2011, p. 102) segundo afirma seu próprio autor, chamar-seia Acerca del todo ausente, cujo título acaba por revelar exatamente a totalidade não encontrada, a qual o personagem tanto busca. Seu manuscrito, apesar de chamar atenção pela espessura, consiste até a página $83 \mathrm{em}$ uma transcrição ipsis litteris das aulas dadas por ele na universidade de Landslide anos antes, já o que vem a partir disso é apenas uma cópia da lista telefônica da cidade.

A intenção do personagem não é assim tão inovadora, já que parece fundamentar-se nos dois grandes termos consagrados durante a segunda metade do século XX para tentar exemplificar a condição particular da sociedade latinoamericana, os quais são usados ainda hoje para trabalhos que envolvam questões, literárias ou não, relevantes a esse território. Dessa forma, são elas o conceito de transculturação, concebido pelo antropólogo cubano Fernando Ortiz na obra Contrapunteo cubano del tabaco y el azúcar (1940) e consagrado pelo uruguaio Ángel Rama em Transculturação narrativa na América Latina (1982), e o de heterogeneidade, que surge após aquele ser criticado por Cornejo Polar em uma

${ }^{24}$ COMÉNIO,1976. (Escrito em 1657). 
nota breve de 1994 intitulada Mestizaje, transculturación, heterogeneidad (SOBREVILLA, 2011, p. 23) 25, fazendo com que Polar forje o segundo termo, o de heterogeneidade, o qual acreditamelhor explicar a situação das literaturas andinas. Ambas serviriam de precedente para a pretensão de Fabián de chegar ao tão almejado ponto de unificação de todaa literatura produzida na América Latina, alcançando a sonhada totalidade latino-americana, a qual esses intelectuais não teriam consigo atingir. No romance, sabe-se que na faculdade em que trabalha o personagem tais estudos são debatidos, visto que Michelle, outra personagem relevante, menciona ainda nas primeiras páginas que havia tido aulas de transculturação com uma professora chamada Ruth Camacho-Stokes ${ }^{26}$ e que nelas havia conhecido seu amigo Sam.

Assim, ao refletirmos sobre os capítulos que se passam na fictícia cidade de Landslide, nos Estados Unidos, durante os anos de 2008 e 2009, é necessário que frisemos, já em primeiro momento, a configuração dos componentes de sua estrutura dêitica, isto é, aquilo que se refere aos personagens, ao tempo e ao espaço desse segmento narrativo: os personagens são a ex-estudante de doutorado Michelle, que também assume a posição de narradora, e seu ex-companheiro, professor universitário Fábian, acerca do qual já falamos acima, bem como seus amigos, estudantesda universidade, Sam e "La Jodida" (que possui um apelido um tanto quanto peculiare condizente com a situação degradante em que ela está inserida, sobre a qual comentaremos mais tarde). Além disso, aparecem em segundo plano os pais de Michelle, os professores e funcionários da universidade e seus colegas de trabalho na franquia de restaurantes fast-food Taco Hut. Já no que concerne ao tempo e ao espaço, as ações desenrolam-se nos ambientes universitários ou em seus arredores e a temporalidade dos fatos é próxima à data de publicação do livro, que ocorre no ano de 2011.

Pensando nos movimentos de diversificação universitária ${ }^{27}$ ao redor do mundo

${ }^{25}$ Ressaltando que a primeira formulação é de 1978, a qual Cornejo Polar denominou El indigenismo y las literaturas heterogéneas: su doble estatuto socio-cultural.

${ }^{26}$ Personagem cujo sobrenome traz a marca da miscigenação: o Camacho é de origem latina, enquanto o Stokes tem procedência anglo-saxônica. Ademais, não há espaçamento entre eles, ambos dividem o mesmo espaço, separados apenas por um hífen, assim como ocorre com os habitantes da fronteira mexicana e estadunidense.

27 Aqui propomos a diversificação universitária em termos de multiplicidade cultural, que se dá a partir do ingresso de estudantes e professores provenientes de diversas nacionalidades, bem como àqueles originários das camadas sócio-econômicas mais baixas, alterando-se a possibilidade de acesso único 
e, especialmente no caso dos Estados Unidos, do qual Michelle faz parte, propomos uma breve reflexão sobre a importância dos estudos latino-americanos terem se estabelecido enquanto cátedra nas universidades estadunidenses, o que os transfigurou em objeto disciplinar. Afinal, antes que haja quem estude é necessário haver o quê estudar. Por isso, a conformação de um cânone literário latino-americano foi fundamental para que a literatura dessa região tenha podido adentrar os restritos corredores e salas nas mais variadas faculdades dos Estados Unidos, como nocaso daquela do romance aqui estudado, ainda que não haja menção alguma a respeito do nome da instituição. $O$ fato de os estudos de Fabián perpassarem os de Rama e Cornejo Polar, assim como a menção à professora que ministra seus conceitos em suas aulas, é um exemplo de como essas cátedras funcionariam na atualidade, bem como da forma como seus componentes usufruem das investigações empreendidas no passado para interpretarem o presente.

Outro ponto interessante é o impacto do ingresso de estudantes e professores oriundos de camadas sociais variadas nas universidades, visto que a democratização do acesso ao ensino superior modifica, ainda que lentamente, quais são os objetos de pesquisa que ali serão desenvolvidos, assim como suas metodologias. Michelle é um exemplo desse ingresso diversificado de estudantes, visto que não pertence à camada mais abastada da sociedade, ainda que tampouco seja uma imigrante ilegal. Seu trabalho cansativo na cadeia de fast-food Taco Hut e o emprego de seu pai consertando televisores para a rede de lojas Best Buy são provas disso. Além disso, outro dado que nos diz sobre a situação socioeconômica da personagem é o medo do desemprego caso seu pai siga a vontade de regressar à Bolívia, o que presumivelmente será concretizado mais tarde, já que ele compra um "one-way ticket" com destino ao país: "[...] era papá, borracho, para decirme que me quería, que cuándo los visitaba, que quizás no lo volvería a ver más, quería unirse a la lucha autonómica en Santa Cruz [...] ¿Quién te daría trabajo, a tu edad?”28.

aos ricos.

${ }^{28} \mathrm{Na}$ narrativa, é possível inferir que Michelle provavelmente teria a pele clara, o que talvez explique em parte seu desinteresse pelas questões referentes aos indígenas e mestiços que cruzam todos os dias a fronteira rumo aos Estados Unidos ilegalmente. Desse modo, um dos dados que nos leva a tal inferência é que seu irmão descobriu apenas já mais velho sua própria identidade latino-americana, o que provavelmente aconteceu mais por conta de sua nação de origem do que por sua etnia. A respeito do desejo de seu pai de retornar a Bolívia, para ingressar na luta autonômica de Santa Cruz, é importante ressaltar que tal movimento é composto majoritariamente pela parcela branca da população boliviana, a qual busca emancipar-se, alegando que possuem condições econômicas, culturais, geográficas e étnicas muito diversas ao resto do país. 
Baseando-nos nas características dadas pela fundamentação dêitica já mencionada, torna-se possível que aproximemos essa parte do romance às narrativas que se constroem sob o gênero das campus novels, as quais são também conhecidas como academic novels, nomenclatura que objetiva designar o gênero de romances cuja trama narrativa tem como espaço principal o ambiente acadêmico das universidades e seus entornos, frequentados por personagens pertencentes a tal âmbito e com enredos centrados nas problemáticas intrínsecas ao território que se conforma dentro dos espaços restritos dos campi universitários. O público-alvo desses romances é formado majoritariamente por pessoas que, assim como os personagens, também fazem parte do circuito acadêmico, as quais podem, por conta disso, resgatar em seu conhecimento de mundo as vastas referências e alusões propostas no decorrer das narrativas como, por exemplo, nomes de obras e de pesquisadores.

Sobre essa temática, no texto What I read and what I read for, Showalter disserta sobre a importância de que o "leitor modelo", seguindo a terminologia utilizada por Eco (1979), reconheça-se na obra que lê. É a partir disso que ocorre o florescimento das campus novel enquanto um campo de produção legítimo e bem estabelecido: "Why is the Academic novel my favorite literary genre? Maybe it's just narcissistic pleasure. One theory about the rise of the novel argues that it developed because readers like to read about their own world and indeed about their selves.". (SHOWALTER, 2005, p.1). Dessa forma, a partir da década de 1950 o gênero ganha espaço no mercado editorial, consolidando-se cada vez mais entre leitores do nicho universitário.

Entre a vasta gama de escritores que recorrem ao gênero das campus novels para produzir seus romances, cada qual o fazendo dentro de sua determinada época de produção e do contexto de sua nação de origem, podemos destacar alguns nomes como os ingleses David Lodge, Malcolm Bradbury, Zadie Adeline Smith eKingsley Amis, os indianos Chetan Bhagat e Avijit Ghosh, os estadunidenses Randall Jarrell e Jeffrey Eugenides, o sul-africano Murhandziwa Nicholas Mhlongo, o neozelandês Christian Karlson Stead e, inclusive, o brasileiro André Rangel Rios, que escreveu o romance Kant em coma, publicado em 2006.

Bem como pode ser visto na nacionalidade dos autores que foram citados acima, durante nossa pesquisa ficou evidente que a maior parte das campus novel, assim como a maioria das investigações sobre elas foram produzidas em países de 
língua predominantemente inglesa, tais como Estados Unidos, Inglaterra, África do Sul, Nova Zelândia e Índia. Entretanto, apesar dessa evidente discrepância, é possível encontrar exceções como os estudos de Susana Gil-Albarellos (2017), Javier García Rodríguez (2015) e Patricia Moore-Martinez (2009) sobre como o gênero realiza-se na Espanha, bem como a dissertação de mestrado do alemão Markus Felsberger (2008), na qual ele busca promover uma comparação intercultural entre os romances enquadrados nessa categoria, e de Aaron Tang Wei Yao (2019), da Nanyang Technological University de Singapura, que discorre a respeito de como se configuram os âmbitos público e privado nas campus novels. Ainda assim, apesar deseus autores saírem do eixo dos países de língua inglesa, as duas últimas pesquisas mencionadas veiculam-se utilizando tal idioma e centram-se principalmente em um corpus de romances escritos por autores estadunidenses e ingleses, o que acaba por reproduzir esse mesmo padrão.

Assim, mantendo-nos no âmbito das campus novels, começamos este capítulo com uma epígrafe extraída da obra White Teeth, de Zadie Smith (2003), autora norteamericana conhecida por escrever livros que giram em torno da vida nos campus universitários, tal qual é o caso do livro mencionado. O trecho, quando aplicado aqui, diz respeito à narrativa em primeira pessoa de Michelle, uma vez que nela dá-se a nós, leitores, o acesso exclusivo a sua forma de ver e interpretar o mundo a sua volta, porém tal vantagem é também o que nos priva dos pensamentos dos demais personagens, o que acaba por produzir uma leitura um tanto quanto restritiva e,até mesmo, obscurecida destes, já que estaríamos utilizando as lentes testemunhais de Michelle.

A construção narrativa adotando esse tipo de tema, isto é, ligada ao âmbito das universidades, não se trata de nenhuma novidade para Paz Soldán, uma vezque Moore-Martinez relembra em sua tese de doutorado um romance anterior do escritor o qual segue uma estrutura temática semelhante àquela encontrada nosegmento de Norte aqui estudado:

In 2001, Edmundo Paz Soldán published La materia del deseo, an academic - mystery novel concerning a young professor, Pedro, who has left his native Bolivia to follow his famous father's academic path. He studies at Berkeley, an institution where the novel is centered, and then lands a job at an unnamed university in the Northeast. His intense love affair with a graduate student engaged to another and his ambivalence about his academic work (he publishes well-received newspaper articles about Latin American politics) send him back to Bolivia for both the summer and a semester sabbatical. (MOOREMARTINEZ, 2009, p. 185). 
Em Norte, são nove capítulos dedicados a esse mote narrativo, os quais, como vimos, são narrados em primeira pessoa por Michelle, personagem-narradora que apesar de tentar afastar-se de seu ex-namorado e, consequentemente, do campo acadêmico do qual ele faz parte é muitas vezes sorvida por eles. Fabián desloca-se diversas vezes das posições de ex-namorado para atual namorado da narradora, a qual apesar de dizer que "hacía inventário de sus defectos" (PAZ-SOLDÁN, 2011, p. 208), mostrando uma abordagem material e técnica de suas falhas ao enumerá-las, não consegue de fato afastar-se dele, já que o racional dessa postura cede lugara expressão exageradamente sentimental que configura todo o relacionamento deles.

Com isso, a relação do casal movimenta-se da mesma forma que a linha de um medidor cardíaco hospitalar: momentos de certa estabilidade e felicidade são interrompidos por épocas extremas de hostilidade, que são acompanhadas por afastamento físico e emocional. Nestas, entre as brigas e ataques, Fabián utiliza apóstrofes para dirigir-se à namorada que evocam infantilidade, como "chiquilla" (PAZSOLDÁN, 2011, p. 101) e "pibita" (PAZ-SOLDÁN, 2011, p. 124), lembrando-a da diferença de mais de dez anos de idade entre eles para censurá-la e impor-se, sendo que quando a chama de "querida" (PAZ-SOLDÁN, 2011, p. 125) o faz apenas de maneira irônica. Além disso, imerso em sua neurose de perseguição, o personagem a acusa em diversos momentos de ser uma espiã dos membros da universidade, já que em sua percepção os deans e os demais professores de seu departamento o estariam perseguindo. Todavia, paradoxalmente, muitas vezes os papéis são invertidose é Michelle quem o passa a tratar de forma infantil ao necessitar controlar seu comportamento impulsivo, conforme ocorre quando o personagem tenta sair em uma noite chuvosa com medo de que estejam vasculhando a lixeira de seu escritório na universidade, apenas para receber a seguinte resposta de sua companheira: " $L O$ siento, perono te voy a dejar salir". (PAZ-SOLDÁN, 2011, p. 101).

Por outro lado, quando estão em tempos de tranquilidade, um apresenta ao outro elementos de suas biblioteca/videoteca/discoteca pessoais: Fábian faz Michelle descubrir a obra cinematográfica da argentina Lucrecia Martel e do francês Philippe Garrel. Já ela, aficionada à cultura de massas, especialmente no que se refere a produções de cunho fantástico, as quais adota como modelo para a criação de sua própria produção literária, não descansou enquanto o namorado não assistiu a todos 
os filmes de Miyazaki e à nova Battlestar Galactica ${ }^{29}$.

Desse modo, trabalhando com os objetos culturais de uso pessoal dos personagens, tais quais livros, filmes, séries televisivas, comics, jornais, revistas e discos (ainda que estes não sejam mencionados em seu aspecto físico), notamos que, por tratar-se de um acervo selecionado a partir de critérios idiossincráticos, essa coletânea é determinante para que tracemos suas características e subjetividades, uma vez que por demandarem um posicionamento crítico de identificação, separação e, muitas vezes, catalogação, dizem bastante a respeito da compreensão de mundo daquele que o colecionou, sendo a ausência desses cuidados também expressiva para a análise.

Seguindo este caminho, ao longo dessa parte do romance são traçadas inúmeras referências e alusões aos objetos mencionados acima, assim como às pessoas reais que os produziram, os quais formam parte da bagagem pessoal não apenas de Michelle e Fabián, os dois personagens principais, mas também dos indivíduos com quem convivem e dos espaços que frequentam.

Um desses personagens secundários é Sam, quem Michelle imagina que em um futuro não tão distante seria "un profesor serio y calvo, incapaz de bromear con sus estudiantes" (PAZ-SOLDÁN, 2011, p. 238). Tal personagem é entusiasta das histórias de grandes assassinos e apresenta um programa semanal na rádio da universidade em que aborda a trajetória de serial killers e massacres que ocorreram em escolas, tratandode embasar teoricamente a análise dos crimes e criminosos a partir dos estudos de Freud, Nietzsche, Sade e Bataille. O programa vai ao ar sempre durante a madrugada, mantendo a atmosfera de mistério própria das horas mais escuras do dia.

Apesar dos conselhos de Michelle para que mude de área e persiga seu interesse pelos estudos da violência, Sam afirma que prefere se comportar bem e terminar sua tese que já está em andamento, para que somente depois que a tenha concluído possa dar aulas nas quais trabalharia com seus alunos esse interesse: "cursos con títulos como «Killing Machines» y haré que mis estudiantes vean Natural Born Killers y les pondré quizzes con preguntas del tipo who was the Railroad Killer or

${ }^{29}$ Miyazaki é cineasta e ilustrador de mangás japonês, sendo um dos fundadores do Studio Ghibli, especializado em animações. Battlestar Galactica, por sua vez, é uma franquia de filmes e séries televisivas de ficção científica do final dos anos 1980, a qual foi retomada em 2003, durando até 2009. Além disso, esta também se apresenta nos formatos de videogame e comics. 
what is The Book of God." (PAZ-SOLDÁN, 2011, p. 122), fazendo uma menção ao serial killer Jesús e ao livro que este escreve em diversos cadernos nos quais explicaria sua trajetória como "ángel vengador", cuja história é contada em outro segmento de Norte e a qual os leitores, nessa altura do romance, já estariam bastante familiarizados.

Dessa forma, no que concerne a Sam, as referências a assassinos em série reais e ficcionais como Eric Harris, Maldoror, Charles Manson, Pedro Alonso López e Jeffrey Dahmer, o qual é citado indiretamente quando o personagem vai ao cinema com Michelle para assistir um filme sobre "un asesino en serie de Milwaukee" (PAZSOLDÁN, 2011, p. 238) são equiparadas em quantidade àquelas de intelectuais célebres como Alan Pauls, Beatriz Sarlo, Heidegger, Blanchot, entre outros. Dessa forma, constroem-se os dois lados extremos em que vive o personagem: um péno mundo acadêmico e o outro no "pure pulp"30 (PAZ-SOLDÁN, 2011, p. 27) de seu programa de rádio. É também Sam que faz a mediação entre esta linha narrativa e a de Jesús, dizendo a Michelle que estava trocando cartas com ele ${ }^{31}$ e levando-a para assistir o momento em que o criminoso é executado na penitenciária de Huntsville, no Texas.

Uma questão complicada da amizade entre Michelle e Sam é que a narradora crê que o rapaz esteja apaixonado por ela. Ele, assim como faz Fabián, a trata por "pibita" (PAZ-SOLDÁN, 2011, p. 187) e "dear" (Ibid., p. 185). Todavia, ao contrário do professor, parece fazê-lo como forma de demonstrar seu afeto. Tal sentimento poderia ser comprovado, ainda segundo a posição de Michelle,porque Sam quando está em sua companhia busca mostrar-Ihe que não é um "académico acartonado" (Ibid., p. 188), isto é, uma figura que ela reprovaria, dada sua repulsa pelo estereótipo do acadêmico que se atém somente à teoria. Sam, apesar dessa postura, acaba por ser honesto com Michelle, usando o que ela afirma ser um "tono condenatório, la arrogancia de superioridad moral' (Ibid., p. 260) e não esconde sua opinião negativa em relação aos comics que Michelle produz: "En vez de dedicarte a cosas importantes,

30 O Cambridge Dictionary dá a seguinte definição ao termo pulp: "books and magazines that are of low quality in the way they are produced and the stories and articles they contain". Disponivel em: <https://dictionary.cambridge.org/pt/dicionario/ingles/pulp>. Acesso: 17.abr.2020.

${ }^{31}$ Aqui é importante que frizemos que Sam troca cartas com o personagem Jesús, de Norte, e não de Ángel Marturino Resendiz, o real Railroad Killer, já que isso é importante para que as duas narrativas confluam, mantendo-se o aspecto ficcional da obra, assim como dando-nos informações sobre ambos personagens. 
seguís con tus dibujitos" (Ibid., p. 260), expressando darmenos valor ao tipo de produção textual feita por Michelle.

Não são raros os momentos em que a figura de Fabián é colocada como oposta a de Sam, um exemplo disso diz respeito à forma distinta que cada um ocupao território acadêmico, retratado na obra como um campo de disputa em que abundam invejas e orgulhos feridos: enquanto este parece estar estritamente focado na escrita de sua tese (ou ao menos é o que deixa transparecer para Michelle), aquele está durante toda a narrativa estagnado na produção de seu livro impossível, sendo que quando tentava trabalhar "se sentaba frente a la computadora para contestar el correo, revisar blogs o hurgar en el disco duro [...]" (Ibid., p. 208), ou seja, não conseguia dar consistência a seu objetivo, perdendo-se em distrações, já que por possuir tenure não poderia ser exonerado de seu cargo na universidade, salvo em condições extremas. Tal proteção, porém, é perdida após uma briga com sua colega de departamento Ruth Camacho-Stokes, o que faz com que o personagem seja demitido e decida mudar-se para a República Dominicana, em busca de sua ex-mulher e de sua filha, abandonando a Academia.

É daí que os livros que se acumulam de forma desordenada nas prateleiras do gabinete de Fabián revelam de forma estereotipada o ambiente acadêmico sobrecarregado e sufocante em que o personagem estaria inserido, já que apesar de sua produção acadêmica estagnada, seria preciso manter as aparências por meio da criação de uma atmosfera de intelectualidade sugerida pelos livros. O clichê encontrase na desorganização que é reforçada pela quantidade de obras, contribuindopara que se mantenha o aspecto de que o personagem seja um leitor ávido, o qual estaria demasiado preocupado com sua pesquisa para perceber a desordem em suavolta.

Essa acumulação de livros se conforma no romance de forma contraditória, visto que só é comparável ao extremo desprezo que o personagem tem deles, adotando ares de superioridade. Assim, Michelle espanta-se ao encontrar diversas pilhas de livros dessa vez espalhados pelo quarto de Fabián, percebendo o caráter paradoxal que essa relação gera: "Para alguien que dice que los libros son una porquería, los hay por todas partes" (PAZ-SOLDÁN, 2011, p. 99). A resposta, por sua vez, segue o padrão de indiferença à produção literária externa e aborda a busca cega por originalidade que é estereótipo do intelectual: "Terminaré mi manuscrito y no volveré a abrir un libro en mi vida. [...] Es la única forma de llegar a algo". (Ibid.,p. 
99).

Tal ambiente provoca uma reação penosa em Michelle ao visualizar e identificar os componentes da biblioteca pessoal do personagem: "Miré los livros en los estantes. Bhabha, Derrida, Sarlo, García Canclini, Culler, Spivak. Me armé de valor."(Ibid., p. 67). O "armarse de valor" de Michelle vem com base no reconhecimento dos nomes de autores consagrados dos estudos culturais, assim como da crítica literária latinoamericana, os quais representam por meio de um processo metonímico a própria produção acadêmica desses estudiosos.

Com isso, o comportamento da personagem ao ganhar coragem (a expressão em português mais próxima semanticamente de armarse de valor) é ambivalente: ao mesmo tempo em que se refere a lidar com a figura complexa que Fabián representa em sua vida, visto que se trata de uma relação mal resolvida, que volta sempre à memória de Michelle, em um movimento de presentificação do passado, é também o não saber lidar com todo o arcabouço de leituras de Fabián, que a fazem sentir-se insuficiente ou uncultured ${ }^{32}$ em relação a ele. Essa insegurança da personagem em relação a ambos (Fabián e a Academia) pode ser vista na fala que ela produz no instante seguinte ao que vê os livros na estante do escritório de Fabián, com o qual não se encontrava havia bastante tempo e estava naquele momento na posição de seu ex-namorado: "[...] Podés leer y escribir lo que te da la gana. Es lo que siempre has hecho. Sólo que... no sé, nunca lo voy a entender del todo." (PAZ-SOLDÁN, 2011, p. 67).

Michelle assume com frequência uma postura que Barros denomina "sujeito recordador" (BARROS, 2006, p.51), na qual a personagem desloca-se a todo o momento, juntamente com o texto por ela narrado, entre as situações que vivencia no presente e as lembranças de seu passado, principalmente no que concerne às memórias de momentos da sua relação com Fabián. Nesse ponto, a conexão que Michelle estabelece com o espaço no tempo presente é o que ativa as recordações do passado, fazendo com que ela se preocupe e tente ao máximo manter os elementos espaciais do mesmo jeito que eram antes de seu afastamento, usando isso como

\footnotetext{
32 O termo uncultured aparece na campus novel Changing Places (1978), de David Lodge, na página 116, na qual os personagens resolvem jogar um jogo nomeado Humiliation. Neste, cada jogador deve confessar não ter lido um livro que imagina que os demais tenham lido. A essência do jogo consiste em expor os lapsos culturais de seus participantes, fazendo com que eles temam ser vistos pelos outros de forma inferior culturalmente, isto é, uncultured.
} 
forma de impedir as mudanças que naturalmente ocorrem com a passagem do tempo e garantir que os momentos felizes do passado ainda sejam possíveis em sua atualidade. Um exemplo desse movimento de resgate por meio da memória, relacionado tempo e espaço, dá-se na cena em que ela utiliza como pretexto o fato de que ainda recebia correspondência em seu escaninho do departamento para ir até à faculdade e encontrar-se com Fabián: "Me detuve en la puerta al lado del ascensor. En la ventana opaca estaban pegadas tiras de Calvin y Hobbes. Nada parecía haber cambiado". (PAZ-SOLDÁN, 2011, p. 63).

É por meio da construção descritiva dos ambientes, como no trecho acima, que o território da memória ${ }^{33}$ é justaposto àquele que é conformado durante seu presente, isto é, o medo de que algo mude em sua ausência e ela já não pertença mais àquele lugar faz com que a todo o momento sua memória seja ativada, interferindo em sua interpretação da realidade. Paradoxalmente, seu oposto, o medo de que nada mude é possivelmente um dos motivos que a faz querer escapar do mundo acadêmico para o mundo fora do campus, que ela própria diz ser o "mundo real": "No era sólo esa sensación de largo paréntesis de la vida que habían significado las clases en la universidad, la aguda sospecha de no estar formando parte del «mundo real»»" (PAZSOLDÁN, 2011, p. 61), confirmando seu posicionamento de que há, de fato, dentro das universidades uma outra conformação territorial completamente distinta daquelas que se constroem nos espaços que estão fora da área de domínio delas.

Ao utilizar como recurso a descrição, a narradora situa o leitor dentro de seu campo de sentidos, incluindo aqueles ativados por sua memória afetiva. Bertrand examina esse tipo de construção discursiva na literatura afirmando que "no discurso descritivo, o ponto de vista se refere diretamente à atividade perceptiva" (BERTRAND, 2003, p. 114). O par memória-descrição vem, assim, nesta linha narrativa como forma de inserir o leitor no território caótico e fluido de onde fala Michelle. Dá a ele um vislumbre do que seria a vida sob a pele de Michelle, com todas suas inseguranças e incertezas, transitando pelo espaço acadêmico, que sente ser demasiado artificial e enganoso, onde ninguém está realmente seguro da própria posição.

Um aspecto interessante do campo de interesses de Michelle é que a jovem mostra ser entusiasta da obra de Rulfo (o qual também é aludido em outras linhas

\footnotetext{
$33 \mathrm{O}$ território da memória aparece aqui em referência ao movimento de presentificação do passado feito pela personagem ao notar certos elementos na composição espacial, como por exemplo, determinados objetos, fazendo com que as lembranças daquele território já vivido sejam ativadas.
} 
narrativas, como vimos nos capítulos referentes a elas) e escreve uma versão distópica de Luvina na qual insere zombies. Há, todavia, um problema nessa composição: a garota menciona diversas vezes ao longo dos primeiros capítulos estar trabalhando em tal versão, o que acaba gerando uma expectativa no leitor.

O resultado final de sua produção literária é, ainda assim, decepcionante,uma vez que quando ela nos é finalmente apresentada, no sétimo capítulo da linha narrativa de Michelle, trata-se de uma transcrição praticamente literal do texto original. Excetuam-se, no caso, as poucas menções a zombies, quase sempre nos momentos em que o narrador do texto originário fala dos ventos ululantes da cidade ou de seus habitantes moribundos, os quais são similares a mortos-vivos no texto de Rulfo e transformam-se em zombies, como prefere Michelle. Isso ocorre devido à inação de tais personagens e a capacidade de fazer com que pessoas recém-ingressas na cidade ajam da mesma forma. Luvina possui uma espécie de encantoque faz com que não consigam abandoná-la, tal qual acontece com milhares de mexicanos que cruzam a fronteira rumo aos Estados Unidos e já não retornam mais a sua pátriade nascença.

Como a campus novel trabalha, como vimos, também com o pressuposto de que o leitor possa identificar dentro de seu conhecimento de mundo as referências específicas ao campo universitário, a narradora reproduz o modus operandi dos textos acadêmicos ao aludir os autores supracitados (inclusive o próprio Rulfo, do qual falávamos acima), além de outros como Žižek e Jean-Luc Nancy. Quer dizer, da mesma maneira que o texto acadêmico possui um tipo leitor específico, já esclarecido naquela determinada área, e busca basear-se em estudos anteriores como forma de ampliar e legitimar sua análise, a narradora faz o mesmo em sua verborragia de nomes prestigiados, porém dessa vez para rechaçá-los, valorizando apenas aos que considera relevante e produzindo, a partir disso, uma transferência de valor dos autores acadêmicos aos que produzem conteúdo para o consumo de massas. Essa é sua forma de conseguir validação para seu próprio trabalho: abandonar o conceito de cultura restrito a erudição, colocando pesquisadores e escritores de comics no mesmo patamar de intelectualidade.

Horacio González no texto Políticas de la Lectura explica que "[...] es sabido que en las vidas menos pedagógicas, donde hay sabiduría, residen muchas veces elementos de una enorme fuerza creativa que a veces se pierden en la universidad' 
(GONZÁLEZ, 2008, p. 168), daí que o temor de Michelle de que o mundo acadêmico sufoque sua criatividade artística não é assim tão infundado, o que faz com que ela precise distanciar-se dele. Daí o movimento de necessitar validar sua própria obra ao equipará-la com a produção que é feita dentro dos moldes acadêmicos, já que segundo sua perspectiva, apesar de seu suposto reingresso no "mundo real", o embate entre literatura canônica e literatura de massas não consegue abandoná-la, ele ainda está fortemente presente em seu cotidiano e em seus pensamentos.

Com isso chegamos a outro embate também presente na linha narrativa estudada, o qual diz respeito às relações de poder que se estabelecem dentro da Academia, especialmente no que concerne à produção cultural ali engendrada sobre as quais Pierre Bourdieu explica:

[...] los profesores universitarios se sitúan más bien del lado del polo dominado del campo del poder y se oponen claramente a ese respecto a los patrones de la industria y del comercio. Pero, en tanto que poseedores de una forma institucionalizada de capital cultural, que les asegura una carrera burocrática e ingresos regulares, se oponen a los escritores y a los artistas: ocupando una posición temporalmente dominante en el campo de la producción cultural, se distinguen por ello, en grados diversos según las facultades, de los ocupantes de los sectores menos institucionalizados y más heréticos de ese campo (y especialmente de los escritores y de los artistas, a los que llaman "libres" o free lance por oposición a aquellos que pertenecen a la universidad). (BOURDIEU ano da citação original, apud CORTEJOSO DE ANDRÉS, 2008, p. 53).

É principalmente por conta do excesso de referências, assim como pelo aspecto caricatural de seus personagens, os quais expressam, consequentemente, suas formas de se relacionar com o território conformado no âmbito acadêmico que desconfiamos de que ocorra nesta linha narrativa um exagero satírico. $O$ objetivo dessa exageração seria promover uma burla a esse mundo acadêmico que, além de excessivamente burocrático e institucionalizado, converter-se-ia em um campo minado para aqueles que o ocupam e ali constroem relações territoriais, já que muitas vezes o desespero desses sujeitos para se manterem relevantes dentro da Academia faz com que sua saúde mental seja prejudicada e toda sua carreira esteja propensa a arruinar-se.

Ana Cortejoso de Andrés usa em sua dissertação de doutorado o exemplo da obra Soy un escritor frustrado, de José Ángel Mañas, na qual "el autor madrileño se adentra en la complejidad del éxito académico y literario y en cómo la ambición por la fama puede desencadenar en la locura" (CORTEJOSO DE ANDRÉS, 2015, p. 138). No romance, um professor universitário estagnado publica o livro de uma alunacomo se fosse de sua autoria, o que faz com que ele alcance a tão sonhada notoriedade, já 
que chega até mesmo a ser premiado pela obra. Por conta disso, a mentira precisa ser sustentada e a fim de mantê-la o personagem comete crimes que o levam à prisão e lá, ironicamente, consegue escrever o próprio romance em questão. Tal personagem pode ser comparado a Fabián, de Norte, principalmente no que diz respeito à obsessão pelo prestígio acadêmico que leva ambos à loucura, ainda que isso ocorra de formas distintas em cada caso, já que o desfecho de Fabián não é a prisão, senão o desemprego, a perda de seu lugar no competitivo mundo acadêmico, sendo condenado à condição de intelectual que um dia foi brilhante, porém cujo destaque foi perdido.

O uso da sátira ao campo acadêmico é, como era de se esperar, uma estratégia um tanto quanto comum dentro do gênero das campus novels, já que a Academia se trata de seu principal assunto. Por conta disso, ela pode ser encontradaem diversos romances dessa esfera. Existem exemplos de obras que exploram essa perspectiva já desde os primórdios do gênero, como acontece com a obra Beer for the Kitten, de Hester Pine, publicado em 1939.

Moore-Martinez é uma das pesquisadoras que afirma, ainda no começo de sua dissertação, que o caráter satírico estaria entre as principais características das campus novel por ela analisadas: "[...] the campus novel emerged as a genre in its own right. In so doing, it acquired certain characteristics that were evident in enough novels that they became inherent to the genre, such as humor and satire, academic jargon and job insecurity". (MOORE-MARTINEZ, 2009, p. 1). Assim sendo, todos os aspectos levantados no trecho acima podem ser encontrados na linha narrativa de Norte aqui estudada, o que corrobora para a ideia de que há de fato uma construção narrativa feita de acordo com os moldes desse gênero literário.

Ao adentrarmos na análise dos personagens, podemos notar algumas características próprias da sátira em suas particularidades: a postura pernóstica de Fabián, em sua obsessão por ser grandioso e seu desdém por seus colegas de profissão, os quais supõe serem seus inimigos, contrasta com a realidade de seu trabalho estagnado e seu consumo descomedido de drogas; Sam em sua vida dupla entre pós-graduando competente e aficionado de crimes sensacionalistas (mesmo que ofaça de forma a contextualiza-los teoricamente); La Jodida, cujo nome não nos é apresentado, apenas a condição decadente que é demonstrada já em seu apelido, a qual decai após ter sido apresentada às drogas por Michelle enquanto frequentavam 
festas universitárias, ingressando em um espiral de queda que culmina com sua possível volta para seu país natal, já que seu baixo rendimento acadêmico faz com que ela perca a bolsa de pesquisa; e, inclusive, a própria Michelle, que em seu afã de afastar-se do mundo universitário aparenta ter medo de ser contaminada pela forma de pensar da Academia: "[...] no encontraría el estímulo para la creatividad entre mis compañeros y profesores, entendería su pasión por la literatura pero no la forma clínica de acercarse a los libros". (PAZ-SOLDÁN, 2011, p. 236).

A figura de Fabián, por sua vez, é construída a partir de um grande clichê: um professor que ainda no começo de sua carreira escreveu uma obra célebre, incluída de imediato nas leituras obrigatórias dos estudantes, mas que após o feito já não consegue mais produzir por conta da pressão acadêmica. Assim, o personagem acumula transtornos, paranoias e processos de autossabotagem, os quais transformam sua vida e ao ambiente em que vive e trabalha no mais completo caos. Apesar disso, há uma autoconfiança extrema a ponto de achar que está sendo perseguido pelos deans e seus colegas de departamento. Quando questionado a respeito do motivo da possível perseguição ele é categórico: "Porque soy demasiado bueno". (PAZ-SOLDÁN, 2011, p. 101).

Há também outros momentos em que a partir de conversas entre Michelle e Fabián é possível notar o desprezo de ambos (ainda que de formas distintas) pela Academia. Michelle pergunta ao professor: "Se escribe más de lo que se puede leer, ¿no?' (PAZ-SOLDÁN, 2011, p. 64), referindo-se ao desespero acadêmico de tentar agarrar tudo, não deixar de conhecer tudo o que já foi publicado. Ao que Fabián responde: "Cada vez leo menos novelas. Bueno, en realidad cada vez leo menos y punto. ¡La cantidad de porquería que se publica!'(PAZ-SOLDÁN, 2011, p. 64), marcando em seu enunciado uma expressão de superioridade, desdém. A conversa continua ao ponto de que passam a refletir sobre a forma como a Academia lida com a literatura: "Académicos como vos también la matan [a la literatura] todos los días. Usan la teoría como un fin en sí mismo. Y escriben esos libros que sólo leen otros académicos". (PAZ-SOLDÁN, 2011, p. 66).

O caráter satírico e, inclusive cômico, é também evidenciado no momento em que enquanto Michelle caminha pelo departamento, em direção à sala de Fabián, vê no mural as fotos dos novos estudantes de pós-graduação acompanhadas das descrições que os próprios fazem de suas pesquisas: "[...] entiende el presente al leer 
los clássicos; el Quijote es el libro más posmo que se pueda encontrar" (PAZSOLDÁN, 2011, p. 62), já que se trata de um anacronismo absurdo ler o Quixote não apenas dentro da perspectiva pós-moderna, mas como o mais pós-moderno. Dando continuidade a isso, ainda em sua caminhada, a personagem nota que a portas dos demais professores estavam fechadas, entre elas a de uma professora renascentista, sobre a qual explica de quem se trata: "conseguía que muchos alunos se inscribieran en sus clases gracias a títulos osados («Sexo, Mentiras y Nada de Videotape: La Celestina»)." (Ibid., p. 63), mais uma vez a anacronia aparece como a ferramenta, dessa vez utilizada pela professora em seu desespero por ter suas classes ocupadas por um número maior de alunos.

Além disso, a narração efetuada por Michelle é permeada de queixas, sendo adotado com frequência um tom de lamento pelas situações do passado e angústia em relação ao futuro. Esse tom frequente de descontentamento seria mais uma característica própria de grande parte dos romances que compõem as campus novel. Chelsea Lynne Klein trata dessa particularidade na introdução de sua dissertação de mestrado sobre o gênero em questão:

The average contemporary American campus novel is a satire boarding on plain old, realistic complaint; and yet, we keep reading. Why?

Kathryn Hume, author of Aggressive Fictions: Reading the Contemporary American Novel, suggests that readers tolerate a complaining narrator because on some level, we can personally validate his or herprimary complaints. Like talking to an old friend, readers forgive complaint if they feel they have personal investment in the complainer or subject of the complaint. (LYNNE KLEIN, 2016, p. vi).

Assim como ocorre com as universidades da obra Changing Places - A Tale of Two Campuses, de David Lodge, a universidade que serve como pano de fundo para as ações nesta parte da narrativa é ficcional, não havendo nem mesmo uma alusão a seu nome, havendo a menção a sua localidade: a cidade imaginária de Landslide, cujo nome em tradução livre para o português, significa deslizamento de terra. Tal nomenclatura nos diz sobre como é conformado o território conflituoso ali desenhado, já que metaforiza a situação instável dos personagens, especialmente dentro do território acadêmico, os quais do mesmo modo em que ocorre com os desabamentos de terra, são passíveis de perder suas posições a qualquer momento, o que ocorre com Fabián, que apesar de possuir tenure, perde seu cargo.

Com isso, a escolha do autor em usar um nome ficcional para a cidade que serve de cenário para desenrolar os fatos e que, consequentemente, serve de nome para a universidade ali localizada, não faz com que falte na narrativa ilusão de 
verdade. São evidências disso toda a estrutura acadêmica que está ali presente, juntamente com a propensão a temas mais próximos dos cotidianos de grande parte de seus leitores, especialmente àqueles que frequentam ou frequentaram os campi universitários como o que é retratado na obra, e conseguem estabelecer similaridades com as situações e lugares descritos na narrativa.

Esse aspecto cotidiano e referencial é o que faz com que esta linha narrativa, cujos personagens pressupomos que sejam totalmente inventados ${ }^{34}$ pelo autor, passe ao leitor um maior efeito de real do que as outras duas trabalhadas nos capítulos anteriores. Afinal, é muito mais fácil reconhecer-se em uma jovem estudante confusa do que em um pintor com esquizofrenia, internado em um hospital psiquiátrico, ouum serial killer, que age com extrema violência ao atacar suas vítimas. Assim, nossa interpretação é que casos específicos como os dois últimos atraem por meio da fascinação e estranhamento produzidos nos leitores, enquanto casos mais genéricos como a narrativa de Michelle provocam neles reconhecimento.

Além disso, há outro elemento que favorece o supracitado reconhecimento do leitor nesta linha narrativa, por tratar-se de um relato construído em primeira pessoa, o uso de um narrador autodiegético aproxima o leitor da sensação de mundo da personagem principal, inserindo o leitor na diegese da obra e criando nele identificação, diferentemente do que ocorre nas outras duas linhas narrativas, cujos relatos são narrados através de um narrador em terceira pessoa.

Michelle, que não se sente plenamente incluída nesse mundo acadêmico, ainda que a maior parte de suas relações interpessoais esteja ali inserida, busca satisfazerse através do que acredita ser uma volta para aquilo que ela crê que seja "o mundo real", isto é, àquele que se refere aos territórios geográficos extra campuse arredores, bem como as territorialidades que se estabelecem nesses espaços. É buscando esse reingresso físico na sociedade convencional que no último capítulode sua linha narrativa a personagem se muda do bairro universitário, afastando-se, com isso, do território acadêmico que se expande para toda região em que a universidade se localiza, já que são frequentados pelas pessoas que a compõem. Além disso, seu trabalho na rede de restaurantes Taco Hut também é marca desse reingresso, jáque Ihe permite conformar relações de outro tipo com os demais trabalhadores.

\footnotetext{
${ }^{34}$ Diferentemente do que ocorre com os personagens Martín Ramírez e Jesús, não há na nota explicativa ao final do livro ou referência alguma acerca de qual(is) seria(m) a(s) possível(is) inspiração(ões) para os personagens que frequentam a fictícia universidade da cidade de Landslide nos anos 2008 e 2009.
} 
Os estabelecimentos ao redor da universidade, dessa forma, são metonimicamente fagocitados para dentro do domínio amplo territorial que se desenha no campus, tornando-se mais um elemento componente dele. Tal tipo de movimento agregador pode ser visto, por exemplo, no café Chip \& Dip, que frequentam diversas vezes os personagens, cujas paredes exibem as notícias do fim de semana com ênfase no conteúdo acadêmico: "[...] una charla de un profesor de Nuevo Laredo sobre la violencia en la fronteral" (PAZ-SOLDÁN, 2011, p.28). Este trecho trata-se de um dos raros momentos em que a fronteira geofísica, tão significativa para o estado fronteiriço do Texas, é efetivamente mencionada, sendo este um caso em que sua relação com os personagens é dada de forma mediada, não direta. Assim, no trecho temos a fronteira vista a partir da perspectiva de uma palestra universitária, desde o olhar acadêmico teorizante, bem diferente da experiência fronteiriça concreta que vivem inúmeras pessoas todos os dias.

Apesar da atitude adotada por Michelle ao tentar fugir e retornar ao que acredita ser a vida normal, está claro seu não pertencimento na realidade da grande maioria dos imigrantes latino-americanos em terras estadunidenses, como ocorre com os habitantes de fronteira supracitados. Michele, como já tratamos, não possui uma condição financeira confortável, mas é altamente escolarizada. Posto isso, sua posição social pode ser definida pela diferenciação que Sayad promove entre estrangeiro e imigrante. Apesar de ambos termos serem vistos como equivalentes no quesito jurídico, Sayad (1998) explica que o que os distingue é a posição social desses sujeitos. Enquanto o vocábulo imigrante alude àqueles aos quais "os efeitos da condição social dobram os efeitos da origem nacional" (SAYAD, 1998, p.268), o estrangeiro teria, por sua posição melhor estabelecida, anulado os efeitos de sua origem. É em consequência desse processo que este é tratado "com o respeito devidoa sua qualidade de 'estrangeiro'” (Ibidem, p.244). Dessa forma, se adotarmos a terminologia proposta por Sayad, os personagens que compõem a linha narrativa aqui estudada, com a possível exceção de Sam, já que não é mencionada sua origem, poderíamos denominá-los estrangeiros, em lugar de dizê-los imigrantes.

Dessa forma, o ambiente acadêmico conturbado, construído pela narração de Michelle, não foge ao que Kingsley Amis retrata em Lucky Jim (1954), visto que também é permeado de festas, casas noturnas e consumo excessivo de álcool, cigarros e drogas, sendo, em Norte, o ápice dessa representação de descomedimento 
a personagem La Jodida. Ademais, outro ponto em comum é a desconfiança em relação à área acadêmica, que estaria composta de pessoas que podem a qualquer momento prejudicar umas às outras. Na obra de Amis, o narrador utiliza como recurso a sátira para expor aquilo acredita ser a experiência de convívio que se estabelece entre os estudantes dos campi universitários ingleses da metade do século XX, época de publicação do livro, traçando uma descrição um tanto quanto dura a respeito de seus componentes:

Their idea of a celebration is to go to a public house and drink six beers. They are mean, malicious and envious. They will write anonymous letters to harass a fellow undergraduate and listen to a telephone conversation that is no business of theirs. Charity, kindness and generosity are qualities that they hold in contempt. They are scum. They will in due leave the university. (KINGSLEY AMIS ano da citação original, apud IBRAHIM ZIDAN, 1954, p. 21).

Há, portanto, nesta linha narrativa de Norte a conformação de dois territórios essencialmente, sendo cada um composto por características particulares a si mesmo, afinal as relações de apropriação simbólico cultural dos espaços em que tais territórios se constroem são sempre configuradas de forma específica às redescomplexas de relações ali tecidas. Dado isso, são eles o território da universidade, o qual é construído sobre o espaço físico do campus universitário, conforme temos desenvolvido ao longo deste capítulo; e o território da fronteira, que ainda que seja menos desenvolvido no segmento que aqui estamos analisando quando comparado com os outros dois já trabalhados nos capítulos anteriores desta dissertação, exige também um cuidado voltado a sua complexidade por tratar-se de uma visão em primeira pessoa de uma personagem que se alheia à situação efetiva que se desenrolana fronteira geopolítica que divide México e Estados Unidos.

Desse modo, a fronteira e a posição do imigrante fronteiriço aparecem explicitamente nas duas vezes que o casal vai brevemente à cidade de El Paso, a qualse situa nesse espaço limiar que divide o "Norte" (leia-se Estados Unidos) de seu sul, mexicano. Na primeira, vão para visitar amigos que vivem na cidade e são surpreendidos por "las oleadas de mexicanos que llegaban de Juárez y buscaban quedarse, tratando de escapar de la guerra entre los carteles y de los intentos desesperados del gobierno por controlarla." (PAZ-SOLDÁN, 2011, p. 123). É importante destacar que essa curta menção aos sujeitos imigrantes que os personagens viram na viagem é feita pela narradora de forma impassível, sendo inclusive grafada dentro de parênteses, como se fosse apenas uma curiosidade e não 
parte do relato.

A segunda viagem à fronteira se dá quando Michelle descobre, durante um período em que Fabián se ausenta de Landslide, que havia engravidado. Este a impele a que faça um aborto e com o objetivo de realizá-lo os dois se deslocam uma vez mais para a cidade fronteiriça de El Paso. Durante a curta estada dos dois no município, eles se alojam em um hotel da rede Holliday Inn, em cuja piscina o professor passa a maior parte do tempo, evitando-a e ambos, consequentemente, afastando-se da realidade que se desenha do lado de fora da hospedagem, isto é, aquela que diz respeito às pessoas que ali chegam, muitas vezes de forma ilegal, e que fixam suas residências naquele espaço. A única referência ao outro lado é quando estão a caminho da clínica: "tomamos un taxi que se perdió por unas callejuelas cercanas a la línea; al fondo se recortaba el cielo de Juárez, más oscuro que el de El Paso, agobiado por el smog de las maquilas". (PAZ-SOLDÁN, 2011, p. 150).

Michelle parece estar demasiado presa às preocupações de seu cotidiano, não se importando em pertencer à pátria alguma, senão a seu próprio mundo interior. O único momento em que se esboça algum pertencimento da personagem à "bolivianeidad" e que logo é desmanchado é quando, com o objetivo de impressionar Fabián, prepara um majao boliviano (prato que consiste em arroz temperado com páprica, charque e ovo frito). Essa experiência, todavia, não é tão bem-sucedida, já que a garota lembra, sem muita nostalgia, daqueles que eram preparados por sua tia Vicentina em Santa Cruz, percebendo que o que havia feito não estava parecido, tranquilizando-se pelo namorado desconhecer a iguaria. Por outro lado, seu pai parece não se esquecer de sua condição enquanto boliviano, ou melhor dizendo, enquanto cruceño, visto que almeja juntar-se à luta separatista do departamento de Santa Cruz de la Sierra do resto da nação, comprando o já citado "one-way ticket" (PAZ-SOLDÁN, 2011, p. 254) para a Bolívia, o que deixa sua mãe desesperada.

A respeito dos estudos acerca dos territórios de fronteira, na introdução à segunda edição de Borderlands/La frontera, livro consagrado da escritora chicana Glória Anzaldúa sobre o domínio territorial que é conformado no traçado geopolítico que separa as nações do México e dos Estados Unidos, Sonia Saldíval Hull afirma que Anzaldúa constrói na obra "una topografía de desplazamiento", na qual define essa fronteira "política e ideologicamente, como un "confín contra la natura»" (ANZALDÚA 1987, p.13). Assim, o caráter de construto artificial da fronteira e a forma como foi 
desprezada a sociedade ancestral que ali habitava e para que fosse efetivada a sua configuração são colocados em análise através do resgate do nome originário daquelas terras, isto é, pré-anexação ao lado estadunidense: Aztlán.

Michelle, Fabián, Sam e os demais personagens, ainda que possivelmente desconheçam essa informação e escolham não lidar com essa problemática, habitam o espaço que algum dia foi Aztlán, a pátria mãe, ferida e desprezada pelo poder simbólico que a dominação cultural traz consigo. O interessante é que, com exceção de Sam, cuja origem é desconhecida, é de certo modo compreensível a despreocupação em relação à compreensão do território extra-acadêmico que se figura no estado do Texas, onde vivem, já que são todos estrangeiros (mantendo o termo empregado por Sayad para referir-se a pessoas oriundas de outros países que possuem uma situação sócio-econômica favorável, como é o caso dos personagens), sendo eles altamente escolarizados e já bastante estabelecidos no território idiossincrático do campus da universidade. Essa condição dos personagens é presumivelmente aquilo que os impede de que ocorra um reconhecimento identitáriocultural com o povo chicano que habita o "lado de fora", mas isso se dá de modo diferenteno caso de Anzaldúa. A autora, nascida às margens do Rio Grande, o qual serve de fronteira natural entre os países, consegue em sua escrita conciliar sua posição enquanto professora universitária e, portanto, ocupante do restrito espaço acadêmico com sua experiência na qualidade de mulher chicana.

Dessa forma, ao preferirem adotar o não posicionamento em relação à fronteira e seus integrantes e/ou transpassantes, esses personagens automaticamente deixam de lidar também com a violência física e simbólica que é instituída nesse território, como ocorre, entre outros muitos exemplos possíveis, na relação desigual em termos de detenção e acesso às estruturas de poder que se estabelece entre os imigrantes ilegais mexicanos que entram nas terras estadunidenses e os policiaisque fazem a patrulha da fronteira. Quando se fala de território, não se debate apenas a questão do domínio de espaço físico, mas fundamentalmente dos corpos que ali habitam e das subjetividades que neles são construídas. Sobre isso, Saldíval Hull declara na introdução à segunda edição da obra de Anzaldúa:

[...] la apropiación de la tierra por parte de los angloamericanos, que hicieron algo más que apoderase de territorio: se trató de un proceso de absorción por parte de Estados Unidos que incluyó la imposición de la Supremacia Blanca, a la que contribuyeron las tácticas abiertamente terroristas de los Rangers de Texas. (ANZALDÚA, 1987, p. 14). 
A fronteira que é construída por Anzaldúa atua como a conformação de uma espécie de terceiro país, o qual é demandado por ambos os lados, mas com características tão peculiares a essa região que, apesar dos intentos de aculturação impostos pelo poderio hegemônico estadunidense e da ancestralidade mexicana, que deteve tal espaço até o acordo de Guadalupe-Hidalgo, assinado em 2 de fevereiro de 1848, registra uma teia cultural intricada e multifacetada, trazendo consigo uma outra possibilidade de existência identitária, uma existência chicana, completamente distinta da experienciada por aqueles que dela não fazem parte. Assim, trata-se de um campo em que se configuram disputas por poder, de viva disputa não apenaspor suas terras, isto é, pelo espaço em si, mas fundamentalmente por território.

Ainda assim, mesmo que a fronteira empírica, ou seja, em seu caráter real como construto efetivo e palpável composto por espacialidade e sujeitos, que pode ser corporalmente transpassado, esteja fora do espaço de convívio dos personagense, consequentemente, de suas formas de interpretar o mundo, tal limite apresenta-seao leitor através de sua representação metaforizada. Assim, enquanto uma parte significativa dos personagens se encontra, como já trabalhamos, de certa forma enclausurados no interior do espaço físico acadêmico, o qual é descrito como um espaço asfixiante, repleto de prédios majestosos sustentados por altas colunas e com corredores em profusão, que se expande a seus arredores para também englobá-los, Michelle escapa e vai à fronteira transfigurada, ou aquilo que entende que possa sêla, refletindo inclusive sobre o papel dos Estados Unidos nessa configuração sócioespacial (ainda que o nome da nação não seja efetivamente mencionado): "un país inmenso en el que se extraviaban y encontraban los latinos." (PAZ-SOLDÁN, 2011, p. 258).

Isso se dá por meio de um romance gráfico que Michelle estaria escrevendo, cuja estrutura inicial é revelada no último capítulo de sua linha narrativa. Em sua composição, a garota combina "elementos de horror y superhéroes" (PAZ-SOLDÁN, 2011, p. 258), situando-o "en el territorio de la literatura fantástica" (Ibid., p. 258), sendo fiel a seus interesses demonstrados ao longo de seu relato, como por exemplo as narrativas que utilizam a linguagem não-verbal para ampliar seu potencial de significação, as quais muitas vezes adotam elementos próprios da fantasia. A partir disso, a personagem delimita o tempo e o espaço das ações: "en un presente com tintes apocalípticos" e "Viven en La Línea, una ciudad de frontera que por el día 
pertenece al Norte y por la noche al Sur" (Ibidem). Já seus personagens, assim como ocorre com a fronteira, são possíveis metáforas dos personagens presentes nas outras linhas narrativas de Norte, Jesús e Martín Ramírez, sendo que o primeiro ela havia recém-conhecido sobre sua história através de Sam e o segundo a havia encantado na exposição feita em sua homenagem pela professora Ruth Camacho- Stokes, além de inserir um personagem que exerceria a função de representar seu ex-namorado, Fabián e, inclusive, ecos de sua própria pessoa.

Assim, todos os principais ejes narrativos de Norte aparecem nessa alegoria, um amálgama metalinguístico que enreda um pouco de todas as trajetórias narradas ao longo do romance em seus personagens: há um cientista que após voltar de viagem descobre que um serial killer havia ingressado em sua casa e assassinado sua filha e estuprado sua esposa, o qual ao longo da narrativa seria revelado que possivelmente teria sido ele mesmo quem teria matado a própria filha (assim como Fabián faz ao persuadir Michelle para que ela fizesse um procedimento abortivo), e violentado sua esposa, pintora imigrante vinda do país ao sul de La Línea e mãe da menina morta, até que esta entrasse em um estado permanente de torpor, mas que antes se interessava por pintar "puentes, trenes, túneles" (PAZ-SOLDÁN, 2011, p. 259), em uma clara referência a Martín Ramírez e seus temas mais frequentes e, possivelmente, uma representação de si própria, por conta de seu sentimento de que Fabián havia conduzido a uma condição de intensa letargia após a cirurgia para que seu aborto fosse realizado. O cientista, que havia alcançado o sucesso quando jovem, cai em depressão e, com isso, sofre de um bloqueio criativo, passando a usardrogas com frequência. É por conta dos delírios que tem durante o consumo dessas substâncias que resolve vestir-se como um super-herói e sair pela cidade combatendo o crime e buscando o assassino de sua filha. Ele, porém, não consegue distinguir claramente a diferença entre o bem e o mal (tal qual ocorre com Jesús, que acredita estar predestinado a ajudar a sociedade de um modo um tanto quanto transtornado: aniquilando-a) e é por conta disso que o personagem tornar-se-ia um serial killer.

Há também, no romance gráfico de Michelle, a representação de uma solução um tanto quanto utópica para o problema da disputa por território entre os dois lados fronteira: cada um ficaria com uma parte do local em um dado período de tempo. Nessa lógica há, porém, um impedimento que não está sendo levado em consideração por Michelle, daí seu caráter essencialmente utópico: não se trata apenas de um 
espaço vazio, mas sim de um território. Dessa forma, o embate se daria para além da questão espacial, já que se trata também do domínio de um povo para que somente assim seja conformada de fato a possibilidade de uma nação. A partir disso, cabe-nos ressaltar que, de certa forma, isso já estaria sendo feito pelos chicanos, os quais ora agem como cidadãos estadunidenses e ora seguem preceitos culturais típicos dos adotados pelos mexicanos. Acreditamos que seja esse o verdadeiro ponto que a personagem implicitamente tem como objetivo destacar.

Além disso, sua temporalidade em um presente com marcas apocalípticas pode também ser relacionada à situação dos que vivem nessa fronteira, afinal Anzaldúa explica que essas pessoas estão constantemente "atrapados entre ser tratados como delincuentes y poder comer" (ANZALDÚA, 1987, p. 53). Tais quais habitantes de uma terra devastada por um apocalipse, a alternativa mais adotada pelos que ali vivem é passar ao outro lado, em busca de melhores condições de sobrevivência, sendo para isso necessário, inclusive arriscar justamente aquilo que mais se busca manter, isto é, a própria vida e, com ela, a própria dignidade.

Com isso, concluímos que o território acadêmico e o território que se conforma na fronteira geofísica entre as nações em questão, magnificamente trabalhadana obra de Anzaldúa, são essencialmente construídos pelos sujeitos (os quais são delimitados sócio-histórico-culturalmente) que ocupam e apropriam-se desses espaços, estabelecendo ali relações interpessoais, nas quais há sempre relações implícitas ou não de poder. Em Norte, tais territórios são vistos, como vimos, de modo quase que antagônicos, dada a dicotomia estabelecida na narrativa entre "mundo acadêmico" e "mundo real", este sendo correlato do território fronteiriço e aquele do território que se conforma dentro do campus universitário retratado na obra, sendo quea ênfase recai no segundo, uma vez que Michelle, a qual acumula as funções de personagem principal e narradora, está essencialmente absorvida por ele por conta de suas relações ainda mantidas com pessoas e espaços referentes a esse âmbito, ainda que o rechace por não se sentir pertencida, recorrendo a outros espaços reais e ficcionais em uma expedição atormentada em busca de autoconhecimento. Isso, todavia, não lhe poderia ser dado ali. 


\section{Considerações finais}

Do mesmo modo que iniciamos esta dissertação falando sobre a força da nova literatura boliviana e o importante papel que a literatura de Edmundo Paz Soldán cumpre nesse cenário. A ressignificação da sociedade boliviana em meio a qual o autor nasceu e cresceu esta presente no romance Norte através da conformação de espaços sociais conflituosos, de modo que as fronteiras simbólicas, tal qual a justaposição do tradicional e do moderno, que convivem de maneira simultânea na Bolívia não o fazem apenas ali, mas também na obra aqui estudada.

Tal síncrese cultural também toma forma nos personagens principais de Norte. Como vimos nos capítulos destinados a cada um, esses são sujeitos que se encontram à margem e é desde ali que buscam construir territórios alternativos para além daqueles em que já estão inseridos involuntariamente, ainda que o façam às suas próprias maneiras. Afinal, o hospital psiquiátrico, o presídio e a universidade, respectivamente referentes a Martín, Jesús e Michelle, são justamente espaços autorreferenciados que oprimem e alienam seus ocupantes.

E é desde tais espaços que os personagens buscam refúgio na arte, na escritura e até mesmo nas drogas, como ocorre no caso de Fabián. Isso se dá por meio de um movimento inicial de desterritorialização que leva, finalmente, a uma nova composição territorial (a qual podemos chamar de reterritorialização), que é conformada no campo simbólico por eles criado, tornando-se um meio para suportar a existência no limite. Trata-se, portanto, de uma forma de resistir à ordem hegemônica pautada nas normas sociais e nas estruturas de vigilância, a qual é especialmente forte nos espaços supracitados, que são construídos tomando como base o fechamento perante a toda sociedade que esteja exterior a seus enormes muros (materiais e simbólicos), o que nos permite estender tal noção à própria nação estadunidense para onde imigram em busca de um norte.

A fronteira fica latente nesse ponto, já que se trata de seres fronteiriços tanto geoespacialmente, quanto simbolicamente. $\mathrm{O}$ deslocamento é feito pelas bordas, com um pé de cada lado. Eles transitam no extremo e é desde esse lugar 
que tentam ressignificar suas existências e a relação territorial intrínseca a elas.

Se não existe desterritorialização plena, senão pela passagem de um território a outro(s), tal qual sustenta Haesbaert (2004), já que para o geógrafo o conceito de sociedade implica a territorialização, o que torna paradoxal a possibilidade de uma territorialização absoluta ou um suposto "fim dos territórios", a falta de um "norte" (presente já desde o título polissêmico do romance), um sentido que os mobilize, faz com que esses personagens sejam sujeitos transitórios, os quais se reinventam em meio à multiplicidade, de modo a ir além "da figura do Estado territorial moderno, defensor de uma lógica territorialista padrão que [...] não admite multiplicidade/superposição de jurisdições e/ou de territorialidade" (HAESBAERT, 2004, p. 21).

É também isso que permite que eles deambulem fisicamente, quando possível, como é caso de Michelle que busca uma nova possibilidade de vida ao mudar-se para longe do campus universitário e Jesús, que usa seu conhecimento acerca do modo como opera a fronteira entre os países em questão para a delinquência, ou através da expressão artística e da memória, caso de Martín, uma vez que todas as vezes que conseguiu escapar do ambiente hospitalar apenas serviram para lhe confirmar que já não cabia no também repressivo "mundo exterior", o qual passa a acessar somente por meio de sua arte.

No caso de Jesús e Michelle, eles não se limitam à fuga espacial ao utilizarem também a escritura como instrumento libertário. Esta o faz com o objetivo de produzir literatura extra-acadêmica, valendo-se para tal de diversos gêneros textuais (o que também faz Paz Soldán ao inserir em Norte elementos típicos das campus novels e dos romances negros e policiais), tais quais os comics e outros elementos da pop culture, incluindo filmes, músicas e séries televisivas. Já aquele despeja todo o seu delírio profético, desde sua suposta posição de "ángel vengador" em uma verve que o leva a compor 14 cadernos que dão forma a seu Libro de las Revelaciones, cujo nome retoma o último livro do Novo Testamento da Bíblia, em que se narra o Apocalipse, revelando uma síncrese religiosa entre paganismo (representado pela figura do Innombrable) e cristianismo, similar àquela que o ocorre em seu México natal.

Há, ainda, mais um ponto a ser levado em questão: a construção esquemática do personagem Fabián, pertencente ao espaço alternativo que seria gerado pelas drogas que consome com frequência não chegando a realizar-se nem dar origem, 
de fato, à criação, mas somente à anulação. É justamente isso o motivo que o leva a ser desligado da faculdade e, consequentemente, à exclusão de seu papel no competitivo território acadêmico.

Michelle, que começa um romance gráfico cujos personagens e enredo metaforizam a obra aqui trabalhada, inicia seu texto pontuando que nele abordará sujeitos que "viven la Línea, una ciudad de frontera que por el día pertenece al Norte y por la noche al Sur". Nada mais simbólico para referir-se às múltiplas territorialidades com as quais eles convivem, uma vez que o sentimento de não-pertencimento tornase ponto em comum.

Em suma, a forma fragmentária do romance reflete a própria fragmentação que se expressa em seu conteúdo através de seus personagens, imigrantes que, apesar de se deslocarem ao norte, são sujeitos em busca de um sentido, de um norte em que possam, finalmente, ancorar-se. Dessa forma, a significação dos territórios e fronteiras experienciados pelos personagens é potencializada em suas subjetividades através da prática da multiterritorialidade (Haesbaert, 2004), mostrando que não há um fim no caminho, deve-se apenas seguir caminhando. 


\section{Bibliografia}

ABRÃO, Joice Aparecida Antonello. Concepções de espaço geográfico e território. Sociedade e Território, Francisco Beltrão, PR, v. 22, n. 1, p. 46-64. 2010.

ADERIBIGBE, Yekeen; et al. Dementia praecox to schizophrenia: the first 100 years. Psychiatry and Clinical Neurosciences, v. 53, n. 4, p.437-448, 1999. Disponível em: https://doi.org/10.1046/j.1440-1819.1999.00584.x. Acesso em: 08 jun. 2021.

AGUILERA TORRADO, Armando. Explicación psicoanalítica del acto criminal. Revista criminalidad, v.52, n.1, p.333-348. 2010. Disponível em < http://ref.scielo.org/v5n63v>. Acesso em: 08 jun. 2021.

ALMADA, Magdalena González. Prácticas identitarias y prácticas cotidianas. Configuraciones de los sujetos paceños en Illimani Púrpura de Juan Pablo Piñeiro. Intersticios de la política y la cultura - Intervenciones latinoamericanas, v.2, n.4, p.56-59, 2013. Disponível em: <https://revistas.unc.edu.ar/>. Acesso em: 08 jun.2021.

ANAYA, Ana Gabriela González. Diagnósticos erróneos: Psicoanálisis de la vida y obra de Martín Ramírez. Revista Iberoamericana para la Investigación y el Desarrollo Educativo, n.10, 2013. Disponível em: <http://111.ride.org.mx/index.php/>. Acesso em: 08 jun. 2021.

ANDRIOLO, Arley. Traços primitivos: histórias do outro lado da arte no século XX. Tese (Doutorado em Psicologia Social). Instituto de Psicologia, Universidade de São Paulo, São Paulo, 2004. Disponível em: <http://doi:10.11606/T.47.2018.tde10092018-145914>. Acesso em 13 jan. 2019.

. O horizonte histórico da arte incomum. Revista Nupeart, [online], v.3, n.3, p. 11-32, 2012. Disponível em: <https://www.revistas.udesc.br/>. Acesso em 08 jun. 2021.

ANSPACH, Silvia. Arte, cura, loucura: uma trajetória rumo à identidade individuada. São Paulo: Annablume, 2000.

ANTÉNE, Petr. Campus Novel Variations: A Comparative Study of an AngloAmerican Genre. Moravia: Palacký University Olomouc, 2015.

ANZALDÚA, Gloria. Borderlands/La frontera: The new mestiza. Madrid: Capitán Swing, 1987.

AMORIN, Marília. "Cronotopo e exotopia". In: Bakhtin: outros conceitos-chave, Beth Brait (org.). São Paulo: Contexto, p. 95-114, 2006.

ARBEX, Daniela. Holocausto brasileiro. São Paulo: Editora Intrínseca, 2019.

ASSIS, Machado. O alienista. Rio de Janeiro: Editora Companhia das Letras, 2014.

AUGÉ, Marc. Los no lugares. Barcelona: Editorial Gedisa, 2000. 
AYERBE, Luis Fernando. Crise de hegemonia e emergência de novos atores na Bolívia: o governo de Evo Morales. Lua Nova: Revista de Cultura e Política, n.83 p. 179-216, 2011. Disponível em: <http://hdl.handle.net/11449/125433>. Acesso em 08 jun.2021.

BÁEZ, Jairo. Lenguaje, discurso y subjetividad en la obra de Martín Ramírez.

Psicosis y psicoanálisis I. v.1, n.1, p. 195-203, 2011.

BARROS, Mariana Luz Pessoa de. Lembrar, esquecer, memorizar, rememorar: memória e modos de existência. Galáxia - Revista do Programa de PósGraduação em Comunicação e Semiótica, PUC, São Paulo, SP, n.33, p. 49-62, 2016. Disponível em: <https://revistas.pucsp.br/index.php/galaxia/>. Acesso em 08 jun. 2021.

BECERRA, Eduardo. ¿Qué hacemos con el abuelo?: la materia del deseo, de Edmundo Paz Soldán. Nexos y diferencias (Entre lo local y lo global: la narrativa latinoamericana en el cambio de siglo, 1996-2006), n. 23, Madrid, Iberoamericana Editorial Vervuert, p. 165-181, 2008.

BERTRAND, D. Caminhos da semiótica literária. Tradução: Grupo Casa. Bauru: Editora da Universidade do Sagrado Coração, 2003.

BILLARD, Henri. McOndo contra Macondo: una confusão de gêneros? Gênero, Niterói, RJ, v.9, n.2, p.19-30, 2009. Disponível em:

<https://periodicos.uff.br/revistagenero>. Acesso em 08 jun. 2021.

BLAY, Eva Alterman. Assassinato de mulheres e direitos humanos. São Paulo: Editora 34, 2008.

BROWN, J. Andrew. Tecnoescritura: literatura y tecnología en América Latina.

$\begin{array}{cllll}\text { Revista } & \text { Iberoamericana, v. 73, } & \text { n. } & 221, & \text { p. } \\ 735-741, & \text { 2007. Disponível em: } & & & \end{array}$
<https://revista-iberoamericana.pitt.edu/>. Acesso em 08 jun. 2021.

CAMARGO, Alfredo. Bolívia: a criação de um novo país, a ascensão do poder político autóctone das civilizações pré-colombianas a Evo Morales. Brasília: Fundação Alexandre de Gusmão, 2006.

CAMBLONG, Ana. "Habitantes de frontera": curso de Pós-Graduação em Literaturas Espanhola e Hispano-Americana. São Paulo: Faculdade de Filosofia, Letras e Ciências Humanas (FFLCH-USP), 2012.

CAMPS, Martín (org.). Cartographies of silence: Martín Ramírez in Stockton in "Dialogues on the Delta: Approaches to the City of Stockton. Newcastle: Cambridge Scholars Publishing, 2018.

COMÉNIO, João Amós. Didática magna: tratado universal de ensinar tudo a todos. Lisboa: Gulbekian, 1976.

CANDIA, Alexis. EI "paraíso infernal" en la narrativa de Roberto Bolaño.

Santiago: Cuarto Propio, 2011. Santiago 
CORNEJO POLAR, Antonio. Escribir en el aire: Ensayo sobre la homogeneidad sociocultural en las literaturas andinas. Lima-Berkeley: Centro de Estudios Literarios Antonio Cornejo Polar (CELACP), 2003.

Mestizaje, transculturación, heterogeneidad. In: Documentos de trabajo: jornadas andinas de literatura latinoamericana (Jalla)-Tucuman, 1995. Revista de Crítica Literaria Latinoamericana, n.40, p.363-374, 1994.

CORTEJOSO DE ANDRÉS, Ana. Born to be a Star: The Metafictional Representation of the Writer as a Global Celebrity in Hispanic Contemporary Narrative (1995-2010). Dissertação (Mestrado em Literatura Hispânica). Pennsylvania: Pennsylvania State University, 2015.

COSTA, Thays Alves. A Arte Bruta de Jean Dubuffet. Palíndromo, v.11, n.25, p. 115-130. 2019. Disponível em: <https://www.revistas.udesc.br/>. Acesso em 08 jun. 2021.

COSTA, Wanderley Messias. Geografia política e geopolítica: discursos sobre o território e o poder. $2^{\text {a }}$ ed. São Paulo: Edusp, 2008.

DEAD MAN TALKING. Entrevistado: Ángel Marturino Résendiz. Entrevistador: Alex Hannaford. [S.I.], out. 2018. Podcast. Disponível em: <https://open.spotify.com/episode/5YU8aiGEAbbphSi7r5cYQD?si=3M3QslseRzSpp4 dyqv1RsA>. Acesso em: 02 maio. 2020.

DELEUZE, Gilles; GUATTARI, Pierre Felix. Mil mesetas. Tradução: José Vázquez Pérez. Valencia Pre-textos, 2004.

DERRIDA, Jacques; VIDARTE, Paco. Mal de archivo: una impresión freudiana. Madrid: Trotta, 1997.

DÍEZ COBO, Rosa María. Globalización y nuevas corrientes poéticas en la narrativa hispanoamericana. In: VII Congreso Internacional Orbis Tertius de Teoría y Crítica Literaria 18, 19 y 20 de mayo de 2009 La Plata. Estados de la cuestión: Actualidad de los estudios de teoría, crítica e historia literaria. La Plata, Universidad Nacional de La Plata. Facultad de Humanidades y Ciencias de la Educación. Centro de Estudios de Teoría y Crítica Literaria, 2009.

DUBUFFET, Jean. Cultura asfixiante. Tradução: Serafim Ferreira. Lisboa: Publicações Dom Quixote, 1970.

ECHEVERRÍA, Esteban. El Matadero. In: Obras Escogidas, p. 123-142. Caracas: Biblioteca Ayacucho, 1991.

ECO, Umberto. The Role of the Reader. Bloomington: Indiana University Press, 1979.

ESPINOSA, Victor M. Martín Ramírez: Framing His Life and Art. Texas: University of Texas Press, 2015. 
FONSECA, Rodrigo Godoy. Arte Bruta e Psicose: nomeação ou tentativa de abertura para o simbólico? Apresentação em congresso. Texto modificado, originalmente apresentado na II Ciranda de Psicanálise e Arte, organizada pelo Museu Nacional de Belas Artes e a Escola Lacaniana de Psicanálise. Rio de Janeiro, 2004.

FONSECA, Tania Mara Galli; et al. Espaços heterotópicos, imagens sobrepostas: Encontros entre arte, loucura e memória. Psicologia: ciência e profissão, v. 29, n.2, p.406-415, 2009.

FORMIGA, Paola. Prefacio. In: Borderlands/La frontera: the new mestiza, de Gloria Anzaldúa. Katatay, v.8, n. 10, set. 2012.

FOUCAULT, Michel. História da loucura na idade clássica. Tradução: José Teixeira Coelho Netto. São Paulo: Perspectiva, 1997.

Vigiar e punir: nascimento das prisões. Tradução: Raquel Ramalhete. Petrópolis: Vozes, 1999.

O poder psiquiátrico: curso dado no Collège de France (1973-1974). Tradução: Eduardo Brandão. São Paulo: Martins Fontes, 2006.

Los espacios otros. Conferência em Cercle des études architecturals. Tradução: Pablo Blitstein e Tadeo Lima. Architecture, Mouvement, Continuité, n.5, out 1984.

FRANCO, Stéfanie Gil. 22 Dezembro 1938 - Arthur Bispo do Rosário: um estudo antropológico sobre arte e loucura. Dissertação. (Mestrado em Antropologia Social). Faculdade de Filosofia, Letras e Ciências Humanas, Universidade de São Paulo, São Paulo, 2011. <http://doi:10.11606/D.8.2011.tde-25052012-100620>. Acesso em: 11 abr. 2018.

FRAYZE-PEREIRA, João. O que é loucura. São Paulo: Brasiliense, 1985.

GABEREL-PAYEN, Sophie. Territoire(s) culturel(s). Les Campus Novels de David Lodge. ILCEA: Revue de I'Institut des Langues et Cultures d'Europe, Amérique, Afrique, Asie et Australie, n.12, 2010.

GARCÍA CANCLINI, Néstor. A globalização imaginada. Tradução: Sergio Molina. São Paulo, lluminuras, 2010.

GARCÍA RODRÍGUEZ, Javier. Escribe cien veces: no me reiré de los profesores (Humor, sátira académica y novela de campus reciente en España). Pasavento Revista de Estudios Hispánicos, v.3, n.2, 2015.

GIUDICE, Dante Severo; COPQUEII, Augusto César da S. Machado. Questões geopolíticas na Bolívia: Possível secessão. Anais do I Congresso Brasileiro de Geografia Política, Geopolítica e Gestão do Território. Rio de Janeiro. Porto Alegre: Editora Letra1; Rio de Janeiro: REBRAGEO, p. 590-598, 2014.

GOFFMAN, Erving. Manicômios, prisões e conventos. Dante Moreira. São Paulo: Editora Perspectiva, 1961. 
GONZÁLEZ, Horacio. Políticas de la lectura. Alea: Estudos Neolatinos, v. 10, n.1, p.161-171, 2008. Disponível em: <https://www.scielo.br/j/alea/i/2008.v10n1/>. Acesso em: 08 jun. 2021.

HAESBAERT, ROGÉRIO. O mito da desterritorialização: do "fim dos territórios" à multiterritorialidade. Rio de Janeiro: Bertrand Brasil, 2004.

. Da desterritorialização à multiterritorialidade. Boletim Gaúcho de Geografia, v. 29, n.1, 2003. Disponível em: <https://seer.ufrgs.br/bgg/article/view/38739>. Acesso em 08 jun. 2021.

Território e Multiterritorialidade: Um Debate. GEOgraphia, v.9, n. 17, 2007. Disponível em: <https://periodicos.uff.br/geographia/article/view/13531>. Acesso em: 08 jun. 2021.

"Concepções de território para entender a desterritorialização". In: SANTOS, Milton. et al. Território, territórios: ensaios sobre o ordenamento territorial. Rio de Janeiro: DP\&A Editora, 2002.

HARGRAVE, Kelly; SEMINET Georgia Smith. De Macondo a Mcondo: Nuevas Voces en la Literatura Latinoamericana. Chasqui, v. 27, n.2, p.14-26, 1998.

IRWIN, R. M. Migración, comodificación, memoria: el caso insólito de Martín Ramírez. A Contracorriente: una revista de estudios latinoamericanos, v.12, n.1, p. 244264, 2014.

KLEIN, Chelsea Lynne. Power Through Privilege: Surveying Perspectives on the Humanities in Higher Education in the Contemporary American Campus Novel. Dissertação. (Mestrado em Literatura de língua inglesa). Winston-Salem: Wake Forest University, 2016.

MARTíN GIJÓN, Mario. Edmundo Paz-Soldán, entre el Norte y el Sur. Resenha. In: Cuadernos Hispanoamericanos, n.732, jun. 2011.

MASSI, Fernanda. Misticismo e religiosidade nos romances policiais contemporâneos: a transgressão do gênero. Estudos Linguísticos, v.40, n.3, p.1793-1803, 2011.

MELMAN, Charles. Imigrantes: Incidências subjetivas das mudanças de língua e país. Tradução: Rosane Pereira. São Paulo: Escuta, 1992.

MICHEL, Valeria Sánchez. Presentación. Para entablar un diálogo entre ciudades universitarias. Istor: revista de história internacional, v. 15, n.58, 2014.

MONTOYA JUÁREZ, Jesús. La narrativa de Edmundo Paz-Soldán o cómo llegamos a ser Sueños digitales. Tonos Digital, v. 13, 2007.

MOORE-MARTINEZ, Patricia. The Emergence of the Spanish Peninsular Campus Novel. Tese. (Doutorado em Literatura em língua hispânica). Pensilvânia: Temple University Libraries, 2009. 
MORA, Luis Vicente. La identidad migrante y su reflejo en los libros sobre inmigración en los Estados Unidos. Impossibilia, n. 2, p. 48-62, out. 2011.

MUÑOZ, Graciela García. Reflexiones sobre la obra de Martín Ramírez. Revista Sans Soleil, n.3, p. 144-152, 2011/2012. Disponível em:

<https://dialnet.unirioja.es/descarga/articulo/4083097.pdf>. Acesso em: 08 jun. 2021.

NANCY, Jean-Luc. À escuta. Tradução: Fernanda Bernardo. Belo Horizonte: Chão de feira, 2014.

NICHOLS, William. Introducción: A los márgenes: hacia una definición de negra. Revista Iberoamericana, v. 76, n. 231, p. 295-303, abr-jun, 2010.

NICOLAISEN, Wilhelm Fritz. Eve's Neighborhood: Fictionalized Factual Place Names in an Off-Campus Novel. Journal of Literary Onomastics, v. 1, n.1, 2011.

PASSETTI, Dorothea Voegeli. A atualidade de Dubuffet: cultura asfixiante. Verve, revista semestral autogestionária do Nu-Sol, n.16, 2009.

PASSETTI, Edson. Loucura e vida como obra de arte. Aisthe, v. 6, n.10, p. 77-87, 2012.

PAYER, Maria Onice. O trabalho com a língua como lugar de memória. Synergies Brésil 7, p.37-46, 2009.

PAZ-SOLDÁN, Edmundo. Norte. Cochabamba: Nuevo Milenio, 2011.

. Los días de la peste. Barcelona: Malpaso Ediciones SL, 2017.

. Cuatro lecturas de La ciudad y los perros. Alicante: Biblioteca Virtual Miguel de Cervantes, 2013. Disponível em <http://www.cervantesvirtual.com/>. Acesso em 11 abr. 2018.

PFRIMER, Matheus Hoffmann. Heartland Sul-americano? Dos discursos geopolíticos à territorialização de um novo triângulo estratégico boliviano. GEOUSP: Espaço e Tempo, n. 29, p. 131-144, 2011.

PROVIDELLO, Guilherme Gonzaga Duarte, and Silvio Yasui. A loucura em Foucault: arte e loucura, loucura e desrazão. História, Ciências, Saúde-Manguinhos, v. 20, n.4, p. 1515-1529, 2013.

RAMOS ORTEGA, Belén. Avatares literarios: Edmundo Paz Soldán o las nuevas tecnologías en la narrativa actual. Alicante: Biblioteca Virtual Miguel de Cervantes, 2013. Disponível em <http://www.cervantesvirtual.com/nd/ark:/59851/bmcq25q0>. Acesso em: 11 abr. 2018.

. "El terror de la migración en Norte, de Edmundo Paz-Soldán”. In: ÁLVAREZ $\overline{M A U R I N}$, María José; LÓPEZ SANTOS, Miriam; SÁNCHEZ VILLADANGOS, Nuria. El Arte frente al terror el terrorismo en la literatura y en el cine: estudios para el recuerdo. León: Universidad de León, 2016. 
RÍO DIÉGUEZ, María del. Creación artística y enfermedad mental. Madrid: Universidad Complutense de Madrid Servicio de Publicaciones, 2004.

RULFO, Juan. El Ilano en Ilamas. México, DF: Fondo de Cultura Económica, 1976.

SÁNCHEZ, Pablo. Después de cruzar la frontera se llega al límite: Norte, de

Edmundo Paz-Soldán. Anuario de Estudios Americanos, v. 73, n. 2, p. 483-498, 2016.

SANTOS, Milton; et al. Território, territórios: ensaios sobre o ordenamento territorial 2. Rio de Janeiro: DP\&A Editora, 2002.

SAVALIYA, Jaydipbhai. Joker in the Pack: A Campus Novel. Research Review International Journal of Multidisciplinary, v.4, n.1, jan. 2019. Disponível em: < https://rrjournals.com/past-issue/joker-in-the-pack-a-campus-novel/\#>. Acesso em:08 jun. 2021.

SAYAD, Abdelmalek. Imigração ou os Paradoxos da Alteridade. Tradução: Cristina Murachco. São Paulo: Edusp, 1998.

SEGATO, Rita Laura. La escritura en el cuerpo de las mujeres asesinadas en Ciudad Juárez: territorio, soberanía y crímenes de segundo estado. Debate feminista, v. 37, p.78-102, 2008.

SELIGMANN-SILVA, Márcio. Colecionismo e arte em Arthur Bispo do Rosário. Trivium, v.1, n.1, p. 2176-4891, 2009.

SERELLE, Marcio. Post de uma revolução em declínio. Cuba na narrativa de Yoani Sánchez in Acontecimentos: reverberações. Belo Horizonte: Autêntica, 2012.

SHOWALTER, Elaine. What I read and what I read for. In: Faculty towers: The academic novel and its discontents. Oxford: Oxford University Press, 2005.

SISKIND, Mariano. Deseos cosmopolitas. Modernidad global y literatura mundial en América Latina. Tradução: Lilia Mosconi. Buenos Aires: Fondo de Cultura Económica, 2016,

SMITH, Zadie. White teeth. Nova York: Vintage, 2003.

SOBREVILLA, David. Transculturación y heterogeneidad: avatares de dos categorías literarias en América Latina. Revista de Crítica Literaria Latinoamericana, LimaHanover, v. 27, n.54, p. 21-33, 2011.

SOUZA, Marcelo Lopes. O Território: Sobre Espaço e Poder, Autonomia e Desenvolvimento. In: ELIAS, Iná (org.); et al. Geografia: Conceitos e Temas. 3aed. Rio de Janeiro: Bertrand do Brasil, 2001.

STEINER, George. Extraterritorial. In: (Idem). Extraterritorial. Ensayos sobre literatura y revolución lingüística. Barcelona: Barral, 1973. 
TESTA, Federico Leonardo Duarte. Perspectiva e alteridade: visões sobre arte, loucura e antropologia. Dissertação. (Mestrado em Artes Visuais). Instituto de Artes (IA-UFRGS). Porto Alegre, 2013.

TOMMASI, Sonia Maria Bufarah. Arte-terapia e loucura: uma viagem simbólica com pacientes psiquiátricos. Campinas: Vetor Editora, 2005.

TONUCCI FILHO, João Bosco Moura. Espaço e território: um debate em torno de conceitos-chave para a geografia crítica. Revista Espinhaço, UFVJM, n.2, p.41-51, 2013.

TRIGO, Abril. Vivir en frontería: a 25 años de Borderlands/La frontera. Katatay, v. 8, n. 10 , set. 2012 .

VASCONCELLOS, Ellen Maria Martins. Entre (ou além) (d)o real e a ficção: a televisão em Realidad, de Sergio Bizzio e Bajo este sol tremendo, de Carlos Busqued. Dissertação. (Mestrado em Literatura de línguas hispânicas). Universidade de São Paulo, 2017.

WEINREB, Mara Evanisa. Imagem e desrazão: Estudo da produção plástica de Manoel Luiz da Rosa (1961-2002). Porto Alegre, 2003. Dissertação. (Mestrado em Artes Visuais). Instituto de Artes (UFRSG). Porto Alegre, 2003.

ZAVALETA, René. Las masas en noviembre. Bolivia Hoy, Siglo XXI, 1983.

ZOSCHKE, Camila. A arte e a loucura: uma aproximação histórica. Anais V Fórum De Pesquisa Científica Em Arte, Escola de Música e Belas Artes do Paraná, Curitiba, 2006-2007, p. 88-97. 